\title{
飽和脂肪酸の摂取基準の考え方
}

\author{
江 崎 治*,1, 窄 野 昌 信 ${ }^{2}$ \\ 三 宅 吉 博 ${ }^{3}$ 井 藤 英 喜 ${ }^{4}$
}

(2006 年 8 月 15 日受付 ; 2006 年 9 月 26 日受理)

\begin{abstract}
要旨：日本人の飽和脂肪酸の摂取基準策定（2005 年版）に用いた論文をエビデンステーブル（表）として 提示し, 策定の基本的な考え方を詳しく述べた。飽和脂肪酸は摂取量が多いと肥満や心筋梗塞が増加し, 少 ないと脳出血が増加する至適攝取範囲の狭い脂肪酸である。このため, 飽和脂肪酸の目標量は 18 歳以上で 4.5\%エネルギー以上， $7 \%$ エネルギー未満に設定された。飽和脂肪酸摂取量が増加すると，肥満度，血中 LDL-コレステロール值が増加し，糖尿病，心筋梗塞罹患が増加する。米国での飽和脂肪酸摂取量を $10 \%$ 工 ネルギー以下 (National Cholesterol Education Program Step I diet) または 7\%エネルギー以下 (National Cholesterol Education Program Step II diet）にした多くの介入研究で，LDL-コレステロール值低下，体 重減少が認められている。米国のコホート研究（観察研究）でも, 飽和脂肪酸摂取量が増加すると, 用量依 存性に心筋梗塞や糖尿病罹患の増加が認められている。日本人の飽和脂肪酸摂取量のエネルギー比率の中央 值（50 パーセンタイル值）は男性 18 歳以上で 4.9-7.2\%エネルギー，女性 18 歳以上で 5.4-7.9\%エネルギー となり，平均では約 $6.3 \%$ エルギーとなる。日本人の現状，あるいは伝統型食生活も考慮に入れて，心筋 梗塞，肥満，糖尿病の予防のため， $7 \%$ エネルギーが目標量（上限）に設定された。日本人中年男女を対象 にした観察研究では，飽和脂肪酸の摂取量が少ないと，血圧，肥満度，コレステロール値，喫煙，アルコー ル摂取量を考慮しても, 脳出血の発症頻度の増加が認められている。ハワイ在住中年男性日系人の観察研究 でも, 飽和脂肪酸の摂取量が $10 \mathrm{~g} / \mathrm{day}$ 未満の人は, $10 \mathrm{~g} / \mathrm{day}$ 以上の人に比べ, 約 2 倍の脳卒中による死亡 数の増加を認めている。これらの研究結果から, 18 歳以上で, $4.5 \%$ エネルギーが下限值に設定された。
\end{abstract}

キーワード : 栄養所要量, 飽和脂肪酸, 心筋梗塞, 脳卒中, 糖尿病

体内での飽和脂肪酸は，飽和脂肪酸を経口捸取しなく ても炭水化物から合成できるので，必須脂肪酸ではな い。このため，推定平均必要量（または推奨量）または 目安量としての下限設定は必要とされていないが，心筋 梗塞, 肥満, 糖尿病, おょび脳出血予防のため, 2005 年版食事摂取基準では目標量が設定されている1)。前回 の第 6 次改定 ${ }^{2)}$ では総脂肪摂取量と飽和脂肪酸との比率 で飽和脂肪酸の摂取目安が示されていたが, 今回の改定 ではエネルギー比率（\%エネルギー）で範囲として示さ れ，大幅な改定となっている（表 1)。

本総説では日本人の飽和脂肪酸の摂取基準策定に用い られた論文を表（エビデンステーブル）として提示し， 策定の基本概念について詳しく述べた。表 2 に示す key word を用いて PubMed から 2003 年 9 月までの論文を 選択した。さらにその中から, 食事摂取基準策定に関連
する論文を選び出し，それぞれの疾病について表として まとめた。最新のデー夕は表には含まれていないが，本 文中で引用した。

\section{飽和脂肪酸の摂取基準は, エネルギー比率で表される}

前回の第 6 次改定 ${ }^{2)}$ では,「飽和脂肪酸 $(\mathrm{S})$, 一価不飽 和脂肪酸 $(\mathrm{M})$, 多価不飽和脂肪酸 $(\mathrm{P})$ の望ましい摂取 割合は概ね $3: 4: 3$ を目安とする。」と記載されている ように, 各脂肪酸の比率で各脂肪酸の摂取目安が示され ていたが，今回は範囲で示され，単位も各脂肪酸で異な る1)。

飽和脂肪酸は一価不飽和脂肪酸や n-6 系脂肪酸と同 様, 摂取の多い脂肪酸で, 疾病罹患リスクのみならず, エネルギー摂取としての意義も考慮する必要がある。す

* 連絡者・別刷請求先 (E-mail: ezaki@ nih.go.jp)

1 独立行政法人国立健康 - 栄養研究所 (162-8636 東京都新宿区戸山 1-23-1)

2 宮崎大学農学部応用生物科学科 (889-2192 宮崎市学園木花台西 1-1)

3 福岡大学医学部公衆衛生学 (814-0180 福岡市城南区七郎 7-45-1)

4 東京都老人医療センター (173-0015 東京都板橋区栄町 35-2) 
表 1 飽和脂肪酸の食事摂取基準（\%エネルギー）

\begin{tabular}{|c|c|c|}
\hline \multirow{2}{*}{ 年 齢 } & 男 性 & 女 性 \\
\hline & 目標量（範囲） & 目標量（範囲） \\
\hline $0-5$ （月） & - & - \\
\hline 6-11（月） & - & - \\
\hline 1-2 （歳） & - & - \\
\hline （歳） & - & - \\
\hline （歳） & - & - \\
\hline 8-9 (歳) & - & - \\
\hline 10-11（歳） & - & - \\
\hline 12-14（歳） & - & - \\
\hline 15-17（歳） & - & - \\
\hline 18-29（歳） & $4.5^{-7.0}$ & $4.5^{-7.0}$ \\
\hline 30-49（歳） & $4.5-7.0$ & $4.5-7.0$ \\
\hline 50-69（歳） & $4.5^{-7.0}$ & $4.5^{-7.0}$ \\
\hline 70 歳以上 & $4.5-7.0$ & $4.5-7.0$ \\
\hline 妊婦 & & $4.5^{-7.0}$ \\
\hline 授乳婦 & & $4.5^{-7.0}$ \\
\hline
\end{tabular}

飽和脂肪酸：C4:0, C6:0, C8:0, C10:0, C12:0, C14:0, C15:0, C16:0, C17:0, C18:0, C20:0, C22:0, C24:0。 注：10 歳以上で，血中 LDL-コレステロール值が高い 場合, 動脈硬化が進行する可能性があるので, 飽和脂 肪攝取量の制限を含めた対策が望まれる。

なわち, エネルギー摂取量が増減した場合, それに連動 して摂取した方がこれらの脂肪酸は摂取しやすい。この ため，エネルギー比率で表してある。

\section{摂取基準は個々の脂肪酸ごとに表すべきか, すべてをまとめ飽和脂肪酸として表すべきか?}

飽和脂肪酸は炭水化物やタンパク質の中間代謝産物,
Acetyl-CoA から合成することができる。飽和脂肪酸は 動物性脂肪やパーム油，ココナッツ油などの熱帯果実に 多く含まれる。飽和脂肪酸には, C4:0, C6:0, C8:0（カ プリル酸), C10:0 (カプリン酸), C12:0 (ラウリン酸), $\mathrm{C} 14: 0$ (ミリスチン酸), C15:0, C16:0 (パルミチン酸), $\mathrm{C} 17: 0, \mathrm{C} 18: 0$ (ステアリン酸)，C20:0，C22:0，C24:0 が ある。LDL-コレステロール増加作用は C12:0, C14:0, C16:0 に認められるが, C18:0 には認められていな ( ${ }^{3-5)}$ 。この原因として, C12:0，C14:0，C16:0 は肝蔵で の LDL-receptor 活性を低下させるが C18:0 は低下させ ないことが考えられている5 。このように，摂取される 個々の脂肪酸は生理効果が異なるため, それぞれの脂肪 酸での摂取基準を策定するのが理想的である。しかし， 飽和脂肪酸を含む食品はいろいろな飽和脂肪酸を同時に 含むことが多い。また，個々の脂肪酸捸取量別に疾病の 罹患率を調べた大規模観察研究は少ない。このため, 2005 年版 ${ }^{1)}$ では, 個々の脂肪酸でなくすべてをまとめ 飽和脂肪酸として，摂取基準を策定した。

\section{飽和脂肪酸の疾病罹患への影響}

\section{1. 総死亡率 (表 3)}

コホート研究 (観察研究) が 2 報677) ある。日系男性を 対象にした研究では, 飽和脂肪酸摂取量が $10 \mathrm{~g} / \mathrm{day}$ (3.9\%エネルギー) 以下の少ない群で死亡率の増加が認 められている。脳卒中による死亡が増加するためだと思 われる6)。しかし，イギリスのベジタリアンを対象にした 研究7) では飽和脂肪酸の摂取量が少なくても死亡率の増 加は認められていない。これは, ベジタリアンでも飽和 脂肪酸の摂取量は 6-14\%エネルギーと日本人に比べ多 いため, 脳出血罹患が増加しないのが理由かもしれない。

表 2 キーワード

飽和脂肪酸共通キーワード (Limits, Human)

(diet [WORD] OR dietary [WORD]) AND saturated [WORD] AND ( (randomized controlled trial [PTYP'] OR random [WORD]) OR (cohort studies [ $\mathrm{MESH}^{2}$ ] OR risk [MESH] OR (odds [WORD] AND ratio [WORD]) OR (relative [WORD] AND risk [WORD]) OR case control [WORD] OR case-control studies [MESH])).

\begin{tabular}{|c|c|c|}
\hline 疾 患 & 疾患別キーワード & 論文検索数 \\
\hline 総死亡 & Death OR Mortality & 237 \\
\hline 虚血性心疾患 & $\begin{array}{l}\text { coronary heart disease OR coronary heart diseases OR coronary artery disease OR } \\
\text { coronary artery diseases OR coronary arteries disease OR coronary arteries diseases OR } \\
\text { ischemic heart disease OR ischemic heart diseases OR ischaemic heart disease OR } \\
\text { ischemic }\end{array}$ & 487 \\
\hline 脳卒中 & $\begin{array}{l}\text { stroke OR brain attack OR intracerebral hemorrhage OR intracerebral hemorrhage OR } \\
\text { intraparenchymal hemorrhage OR intraparenchymal hemorrhage OR cerebral hemor- } \\
\text { rhage OR cerebral hemorrhage OR hemorrhagic stroke OR hemorrhagic stroke OR } \\
\text { subarachnoid hemorrhage }\end{array}$ & 51 \\
\hline 肥 満 & Obesity & 213 \\
\hline 糖尿病 & diabetes OR insulin resistance & 232 \\
\hline がん & Neoplasmas [MESH] & 282 \\
\hline 骨粗鬆症 & osteoporosis & 5 \\
\hline
\end{tabular}

${ }^{1}$ PTYP, Publication type; ${ }^{2} \mathrm{MESH}, \mathrm{MeSH}$ terms. 
表 3 総死亡率

\begin{tabular}{|c|c|c|c|c|}
\hline 発表年 & 著者・国 & 対象・方法 & 結＼cjkstart果 & 文献番号 \\
\hline 1985 & $\begin{array}{l}\text { McGee D } \\
\quad \text { 米国 }\end{array}$ & $\begin{array}{l}\text { コホート研究 : } 1900-1919 \text { 年に生まれたハワイに住 } \\
\text { んでいる男性日系人 } 11,000 \text { 人の食事調査と } 10 \text { 年間 } \\
\text { の死亡率との関連を調べた。 }\end{array}$ & $\begin{array}{l}\text { 脂肪摂取量の少ない人は死亡率が高かった。特に飽和 } \\
\text { 脂肪酸の摂取量が } 10 \mathrm{~g} / \mathrm{day} \text { 以下だと, 死亡率（特に } \\
\text { 脳卒中とがん）が約 } 2 \text { 倍に増加した。飽和脂肪酸の摂 } \\
\text { 取量が多くても死亡率は増加しなかった。 }\end{array}$ & 6 \\
\hline 1991 & $\begin{array}{l}\text { Kesteloot H } \\
\text { ベルギー }\end{array}$ & $\begin{array}{l}\text { エコロジカル研究：1979-1981 FAO データから } 36 \\
\text { カ国の乳製品とラード由来の脂肪摂取量と, 各国別 } \\
\text { の死亡率の関連を調べた。 }\end{array}$ & $\begin{array}{l}\text { 男性において, 飽和脂肪酸摂取量と総死亡率 }(r= \\
0.43) \text { との間に正の相関が認められた。 }\end{array}$ & 8 \\
\hline 1997 & $\begin{array}{l}\text { Staessen L } \\
\text { ベルギー }\end{array}$ & $\begin{array}{l}\text { エコロジカル研究: ベルギーにいる } 11,302 \text { 人を対 } \\
\text { 象に, } 42 \text { の地域別栄養調査を行い, 各地域の死亡率 } \\
\text { との関連を調べた。 }\end{array}$ & $\begin{array}{l}\text { 飽和脂肪酸の摂取量 (平均で男 } 54 \mathrm{~g} / \mathrm{day} \text {, 女 } 41 \mathrm{~g} / \\
\text { day) と, 死亡率との弱い正の相関 }(R R=1.04) \text { が認 } \\
\text { められた。 }\end{array}$ & 9 \\
\hline 1999 & $\begin{array}{l}\text { Appleby PN } \\
\text { イギリス }\end{array}$ & $\begin{array}{l}\text { コホート研究：イギリスのベジタリアン } 6,000 \text { 人 } \\
\text { (脂肪エネルギー比 } 34 \% \text { ) と, そうでない人 } 5,000 \text { 人 } \\
\text { を対象とし, } 12 \text { 年間の総死亡率と, 食品摂取量との } \\
\text { 関連を調べた。 }\end{array}$ & $\begin{array}{l}\text { ベジタリアンは肉食を好む人に比較し, 総死亡が } 0.91 \\
(0.75-1.09) \text { と軽度減少。 }\end{array}$ & 7 \\
\hline 2000 & $\begin{array}{l}\text { Kromhout D } \\
\text { オランダ }\end{array}$ & $\begin{array}{l}7 \text { 力国観察研究 : 世界 } 7 \text { 力国のコホート研究に参加 } \\
\text { している } 5,973 \text { 人の男性を対象。食事調査を定期的 } \\
\text { に行い, } 25 \text { 年間の死亡率との関連を調べた。 }\end{array}$ & $\begin{array}{l}\text { 飽和脂肪酸, 食物繊維, ビタミン } \mathrm{C}, \text { フラボノイド, 喫 } \\
\text { 煙, アルコールの危険因子の中で, 飽和脂肪酸が総死 } \\
\text { 亡との関連が最も高く, 飽和脂肪酸の摂取量が多い国 } \\
\text { ほど, 総死亡率が高かった。 }\end{array}$ & 10 \\
\hline
\end{tabular}

摂取量が多いときの影響は，コホート研究とエコロジ カル研究で結果が異なる。二つのコホート研究6)7)では, 飽和脂肪酸の摂取量が多くても死亡率の顕著な増加は認 められていない。一方, 国, または地域ごとに比べたエ コロジカル研究は 3 報 ${ }^{8-10)}$ あり, どれも飽和脂肪酸の捸 取量の多い国, 地域で総死亡率が増加している。しか し, エコロジカル研究は他の交絡変数（各国の経済力, 衛生状態, 乳児死亡率, 喫煙など死亡に関係する因子) の補正がされていないので, 飽和脂肪酸摂取量増加が原 因で死亡率が増加したかどうかは明らかでない。

\section{2. 心筋梗塞 (表 4)}

飽和脂肪酸摂取量が増加すると血中 LDL-コレステ ロール值は増加する ${ }^{11-13)}$ 。また, LDL-receptorの欠損 している人は, 血中 LDL-コレステロール值が増加し (家族性高コレスレロール血症), 若いときから動脈硬化 症を発症することから, 血中 LDL-コレステロールの増 加は人での心筋梗塞の危険因子であることは間違いな (14)。すなわち, 飽和脂肪酸の㩒取が増加すると, 血中 LDL-コレステロールが増加し, 動脈硬化が促進される ようになることは容易に推定される。一方, 飽和脂肪酸 の摂取量増加は心筋梗塞を予防する HDL-コレステロー ルも増加させる ${ }^{15)}$ 。このため, 飽和脂肪酸をどれだけ捸 取すると有意な心筋梗塞のリスクとなるかが問題にな る。

表 4 に示すように, 過去の飽和脂肪酸摂取量と心筋梗 塞との関連を調べた九つの大規模観察研究（コホート研 究 $)^{6) 16-25)}$ から結果が報告されている。喫煙者を対象に した研究 ${ }^{20)} と$ Nurses' Health Study ${ }^{2123) 24)}$ を除くすべ ての研究で飽和脂肪酸捸取量と心筋梗塞死亡との正の関 連が認められている。Nurses' Health Study ${ }^{24)}$ では多 くの交絡変数で補正すると, 飽和脂肪酸摂取量と心筋梗 塞死亡の有意な正の関連は消失し, 飽和脂肪酸の種類別

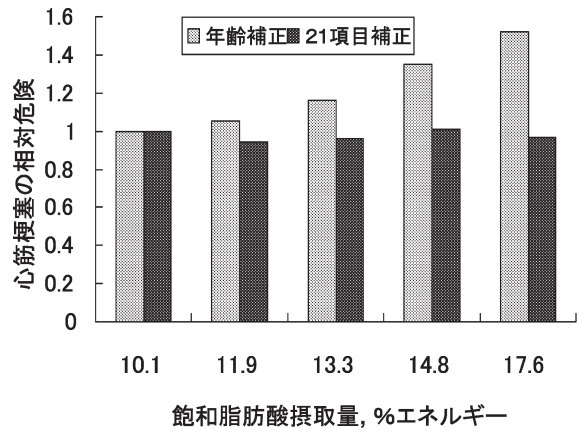

図 1 飽和脂肪酸摂取量と心筋梗塞罹患との相対危 険 (Nurses' Health Study ${ }^{26)}$ )

米国看護婦約 8 万人を 1980 年に登録しておき，食 生活を含む生活習慣を定期に調査し, 20 年間フォ ローし，1,766 例の心筋梗塞が認められた。飽和脂 肪酸の心筋梗塞罹患への関与を pooled logistic regression 分析法で調べた。21 項目の交絡変数と して, 年齢, BMI, 喫煙, アルコール飲量, 両親 の心筋梗塞の既往, 高血圧歴, 更年期の状態, アス ピリン服用の有無, 総合ビタミン剤, ビタミン $\mathrm{E}$ 服用の有無, エネルギー, タンパク質, コレステ ロール摂取量, 一価不飽和脂肪酸, 多価不飽和脂肪 酸, トランス脂肪酸摂取量, リノレン酸, 魚由来の $\mathrm{n}-3$ 脂肪酸, シリアルファイバー, フルーツ, 野菜 を考慮した。

に分析しても，たとえば C16:0 の摂取が増加しても心筋 梗塞罹患が増加することはない。新しく 2005 年に発表 された Nurses' Health Study ${ }^{26)}$ の結果でも, 21 項目の 補正によりこの関連は消失している（図 1)。残念なが ら，21 項目の補正の中で，どの項目が飽和脂肪酸の心 筋梗塞罹患へのリスク消失に関与するかは明らかでな い。21 項目の補正をせず，年齢補正のみの場合，図 1 に示すように用量依存性の心筋梗塞の増加が認められて 


\begin{tabular}{|c|c|c|c|c|}
\hline 発表年 & 著者・国 & 研究デザイン & \multicolumn{2}{|c|}{ 食事調査法, その他 } \\
\hline 1979 & $\begin{array}{l}\text { Turpeinen O } \\
\text { フィンランド }\end{array}$ & $\begin{array}{l}\text { 介入研究 } \\
\text { 精神病院入院中の中年男性 } 676 \text { 人 } \\
\mathrm{K} \text { 病院で } 6 \text { 年間 SCLdiet, } 6 \text { 年間 NORMdiet } \\
\mathrm{N} \text { 病院で } 6 \text { 年間 NORMdiet, } 6 \text { 年間 SCLdiet }\end{array}$ & $\begin{array}{l}\text { SCLdiet=飽和脂肪酸 } 27 \mathrm{~g} / \text { day } \\
\text { NORMdiet=飽和脂肪酸 } 55 \mathrm{~g} / \text { day }\end{array}$ & $\begin{array}{l}\text { 介入食 } \\
\text { SCL diet } \\
\text { NORM diet }\end{array}$ \\
\hline 1981 & $\begin{array}{l}\text { Keys A } \\
\text { 米国, オランダ, } \\
\text { ユーゴスラビラ, } \\
\text { ギリシャ, イタリア, } \\
\text { 日本, フィンランド }\end{array}$ & $\begin{array}{l}\text { エコロジカル研究 }(10 \text { 年間) } \\
\text { 男性 } 12763 \text { 人 } \\
413 \text { 人が心筋梗塞で死亡 } \\
\text { Seven Countries Study }\end{array}$ & & $\begin{array}{l}\text { 食事由来脂肪酸の種類 } \\
\text { 飽和脂肪酸 } \\
\text { 一価脂肪酸 }\end{array}$ \\
\hline 1985 & $\begin{array}{l}\text { McGee D } \\
\text { 米国，対象は日本人 }\end{array}$ & $\begin{array}{l}\text { コホート研究 }(10 \text { 年 }) \\
\text { 日系男性 } 8006 \text { 人 } \\
\text { 心筋梗塞死亡は } 99 \text { 人 } \\
\text { Honolulu Heart Program }\end{array}$ & 24 時間思い出し法 & $\begin{array}{l}\text { 飽和脂肪酸摂取量 } \\
\quad \text { (エネルギー\%) } \\
7 \text { 未満 } \\
7-9 \\
9-11 \\
11-13 \\
13-15 \\
15 \text { 以上 }\end{array}$ \\
\hline 1985 & $\begin{array}{l}\text { Kushi LH } \\
\text { 米国 }\end{array}$ & $\begin{array}{l}\text { コホート研究 }(20 \text { 年 }) \\
\text { 中年男性 } 1001 \text { 人 } \\
\text { 心筋梗塞死亡は } 110 \text { 人 } \\
\text { Ireland-Boston } \\
\text { Diet-Heart Study }\end{array}$ & $\mathrm{FFQ}^{1}$ & $\begin{array}{l}\text { 食事由来脂肪酸の種類 } \\
\text { 飽和脂肪酸 } \\
\text { (エネルギー\%) } \\
\text { 多価不飽和脂肪酸 } \\
\text { (エネルギー\%) } \\
\text { コレステロール } \\
(\mathrm{mg} / 1000 \mathrm{kcal})\end{array}$ \\
\hline 1990 & $\begin{array}{l}\text { Blankenhorn DH } \\
\text { 米国 }\end{array}$ & $\begin{array}{l}\text { 介入研究 }(\mathrm{RCT}) \quad(2 \text { 年間) } \\
\text { バイパス手術既往のある男性 } 188 \text { 人 } \\
\text { エンドポイントは新規冠動脈病変発症 }\end{array}$ & 24 時間思い出し法（2 回） & $\begin{array}{l}\text { 飽和脂肪酸摂取量 } \\
\text { (エネルギー\%) } \\
5.2 \text { 以下 } \\
5.2-7.1 \\
7.1-10.1 \\
10.1 \text { 以上 }\end{array}$ \\
\hline 1991 & $\begin{array}{l}\text { Posner BM } \\
\text { 米国 }\end{array}$ & $\begin{array}{l}\text { コホート研究 }(16 \text { 年 }) \\
45-55 \text { 歳男性 } 420 \text { 人 } \\
56-65 \text { 歳男性 } 393 \text { 人 } \\
\text { Framingham Study }\end{array}$ & 24 時間思い出し法 & $\begin{array}{l}\text { 各種脂肪摄取 } \\
\quad(\text { エネル゙ー\%) } \\
\text { 総脂肪 } \\
\text { 飽和脂肪酸 } \\
\text { 一価不飽和脂肪酸 } \\
\text { 多価不飽和脂肪酸 } \\
\text { コレステロール }\end{array}$ \\
\hline 1993 & $\begin{array}{l}\text { Tzonou A } \\
\text { ギリシャ }\end{array}$ & $\begin{array}{l}\text { 症例対照研究 } \\
\text { 冠動脈疾患患者 } 329 \text { 人 } \\
\text { コントロール患者 } 570 \text { 人 }\end{array}$ & $\mathrm{FFQ}$ & 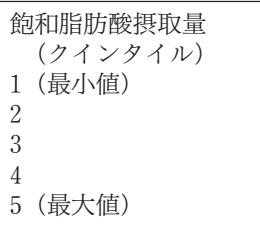 \\
\hline 1994 & $\begin{array}{l}\text { Watts GF } \\
\text { イギリス }\end{array}$ & $\begin{array}{l}\text { 介入研究 (39 力月) } \\
\text { 冠動脈疾患男性 } 50 \text { 人 }\end{array}$ & 3 日間の FFQ 2 回 & $\begin{array}{l}\text { 食事内容 } \\
\text { 総摂取エネルギー } \\
\text { 総脂肪 } \\
\text { 飽和脂肪酸 } \\
\text { 一価不飽和脂肪酸 } \\
\text { 多価不飽和脂肪酸 } \\
\text { コレステロール }\end{array}$ \\
\hline 1995 & $\begin{array}{l}\text { Kromhout D } \\
\text { 米国, オランダ, } \\
\text { ユーゴスラビラ, } \\
\text { ギリシャ, イタリア, } \\
\text { 日本, フィンランド }\end{array}$ & $\begin{array}{l}\text { エコロジカル研究（25 年間） } \\
\text { 中年男性 } 12763 \text { 人 } \\
\text { 個人別でなく，16 のコホート別に分析 } \\
\text { Seven Countries Study }\end{array}$ & $\begin{array}{l}\text { 各コホートの一部の人の } \\
\text { 食事摂取調査 }\end{array}$ & $\begin{array}{l}\text { 摂取脂肪酸の種類 } \\
12: 0 \\
14: 0 \\
16: 0 \\
18: 0 \\
\text { 飽和脂肪酸 }\end{array}$ \\
\hline 1996 & $\begin{array}{l}\text { Esrey KL } \\
\text { カナダ }\end{array}$ & $\begin{array}{l}\text { コホート研究 }(12 \text { 年 }) \\
30-59 \text { 歳男女 } 3925 \text { 人 } \\
60-79 \text { 歳男女 } 621 \text { 人 } \\
12 \text { 年間でそれぞれ } 52 \text { 人, } \\
40 \text { 人が心筋梗塞で死亡 }\end{array}$ & 24 時間思い出し法 & $\begin{array}{l}\text { 脂肪摂取量 } \\
\quad(\text { エネル゙ー\%) } \\
\text { 総脂肪 } \\
\text { 飽和脂肪酸 } \\
\text { 一価不飽和脂肪酸 } \\
\text { 多価不飽和脂肪酸 } \\
\text { コレステテロール }\end{array}$ \\
\hline 1996 & $\begin{array}{l}\text { Ascherio A } \\
\text { 米国 }\end{array}$ & $\begin{array}{l}\text { コホート研究 }(6 \text { 年 }) \\
40-75 \text { 歳男性 } 43757 \text { 人 } \\
734 \text { 人が心筋梗塞に罹患 } \\
229 \text { 人が心筇梗塞で死亡 } \\
\text { Health Professionals } \\
\text { follow up study }\end{array}$ & FFQ & $\begin{array}{l}\text { 飽和脂肪酸摂取量 } \\
\text { (g/day) } \\
17 \\
21 \\
24 \\
27 \\
33\end{array}$ \\
\hline
\end{tabular}




\begin{tabular}{|c|c|c|c|}
\hline & 結 果 & コメント & $\begin{array}{l}\text { 文献 } \\
\text { 番号 }\end{array}$ \\
\hline $\begin{array}{l}\text { 虚血性心疾患 (人/1000 人/年) } \\
13.5 \\
24.3\end{array}$ & & $\begin{array}{l}\text { 飽和脂肪酸を半分に減少させた食事で } \\
\text { 虚血性心疾患が半減。 }\end{array}$ & 35 \\
\hline $\begin{array}{l}\text { 心筋梗塞死亡の偏相関係数 } \\
37 \quad(t=5.8) \\
-8.4\end{array}$ & & $\begin{array}{l}\text { 飽和脂肪酸摂取量と心筇梗塞死亡とは } \\
\text { 関連が蚛い }(r=0.84) \text { 。 }\end{array}$ & 31 \\
\hline $\begin{array}{l}\text { 心筋梗塞死亡数/1000 人 } \\
6 \\
14 \\
13 \\
12 \\
11 \\
22\end{array}$ & 偏相関係数 $=0.168$ で有意差なし & $\begin{array}{l}\text { 有意ではないが, 飽和脂肪酸攝取量が } 7 \\
\text { エネル゙ー\%以上の人筋梗塞死亡が } \\
\text { 多い。 } \\
\text { (年齢, 収縮期血圧, BMI, 運動量, 喫煙 } \\
\text { で補正) }\end{array}$ & 6 \\
\hline $\begin{array}{l}\text { coefficient } \\
0.061 \\
-0.07\end{array}$ & $\begin{array}{l}p \text { value (Cox proportional model) } \\
0.05 \\
0.45\end{array}$ & 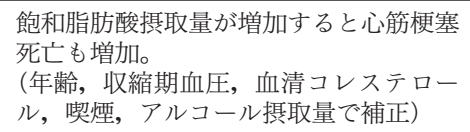 & 16 \\
\hline 0.0017 & 0.1 & & \\
\hline $\begin{array}{l}\text { 新規冠動脈病変発症 } \\
\quad \text { (相対危険) } \\
1\end{array}$ & & $\begin{array}{l}\text { 有意ではないが, 飽和脂肪酸摄取量が } \\
7.1 \text { エネルギー\%以上の人冠動脈病変 } \\
\text { が多い。 } \\
\text { (年齢, 食事内容, 血清コレステロールール, } \\
\text { 血圧で補正) }\end{array}$ & 36 \\
\hline $\begin{array}{l}45-55 \text { 歳 } \\
\quad \text { (Cox Regression Coefficient) } \\
0.035(p=0.005) \\
0.047(p=0.052) \\
0.071(p=0.004) \\
0.065(p=0.1) \\
0.000(p=0.92)\end{array}$ & $\begin{array}{l}56-65 \text { 歳 } \\
\quad \text { Cox Regression Coefficient }) \\
0.004 \quad(p=0.973) \\
0.011 \quad(p=0.611) \\
-0.004 \quad(p=0.867) \\
0.051 \quad(p=0.187) \\
0.0003 \quad(p=0.364)\end{array}$ & 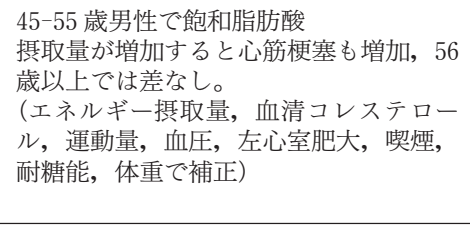 & 17 \\
\hline 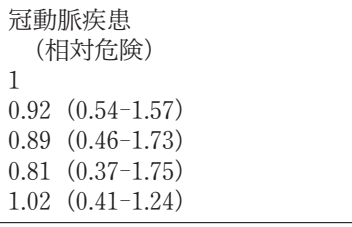 & & 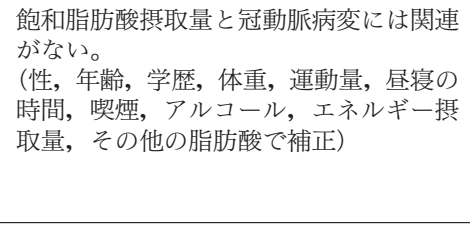 & 28 \\
\hline $\begin{array}{l}\text { 冠動脈径減少程度との関連 } \\
r=-0.46 \quad(p=0.001) \\
r=-0.55 \quad(p<0.001) \\
r=-0.44 \quad(p=0.001) \\
r=-0.33 \quad(p=0.016) \\
\text { 差なし } \\
r=-0.27(p=0.001)\end{array}$ & & $\begin{array}{l}\text { 飽和脂肪酸摂取量が多いと冠動脈がより } \\
\text { 狭くなる。 }\end{array}$ & 37 \\
\hline $\begin{array}{l}\text { 心筋梗塞死亡の関連 } \\
0.84 \quad(p<0.001) \\
0.86 \quad(p<0.001) \\
0.81 \quad(p<0.001) \\
0.84 \quad(p<0.001) \\
0.88 \quad(p<0.001)\end{array}$ & & $\begin{array}{l}\text { 飽和脂肪酸摂取量が多いコホートほど, } \\
\text { 心筋梗塞死亡が多い。 }\end{array}$ & 32 \\
\hline $\begin{array}{l}30-59 \text { 歳 } \\
\quad(\text { 相対危険, } \exp (\text { beta })) \\
1.04 \quad(p<0.05) \\
1.11(p<0.01) \\
1.08(p<0.05) \\
0.99 \text { (NS) } \\
1.00 \text { (NS) }\end{array}$ & $\begin{array}{l}60-79 \text { 歳 } \\
\text { (相対危険, exp (beta)) } \\
0.99 \text { (NS) } \\
0.96 \text { (NS) } \\
1.00 \text { (NS) } \\
1.00 \text { (NS) } \\
1.01 \text { (NS) }\end{array}$ & 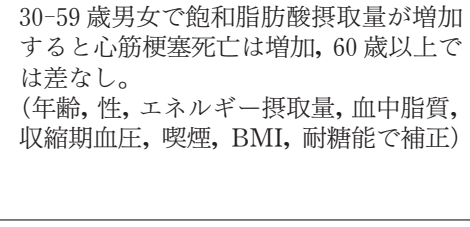 & 18 \\
\hline 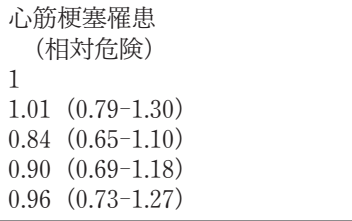 & $\begin{array}{ll}\begin{array}{l}\text { 心筋梗塞死亡 } \\
\quad \text { (相対危険 })\end{array} \\
1 & \\
1.41 & (0.87-2.31) \\
1.38 & (0.83-2.28) \\
1.32 & (0.79-2.22) \\
1.72 & (1.01-2.90)\end{array}$ & 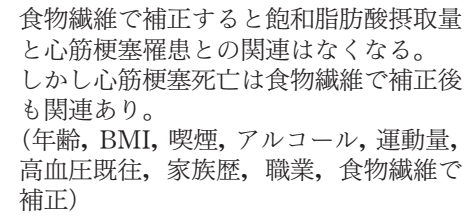 & 19 \\
\hline
\end{tabular}




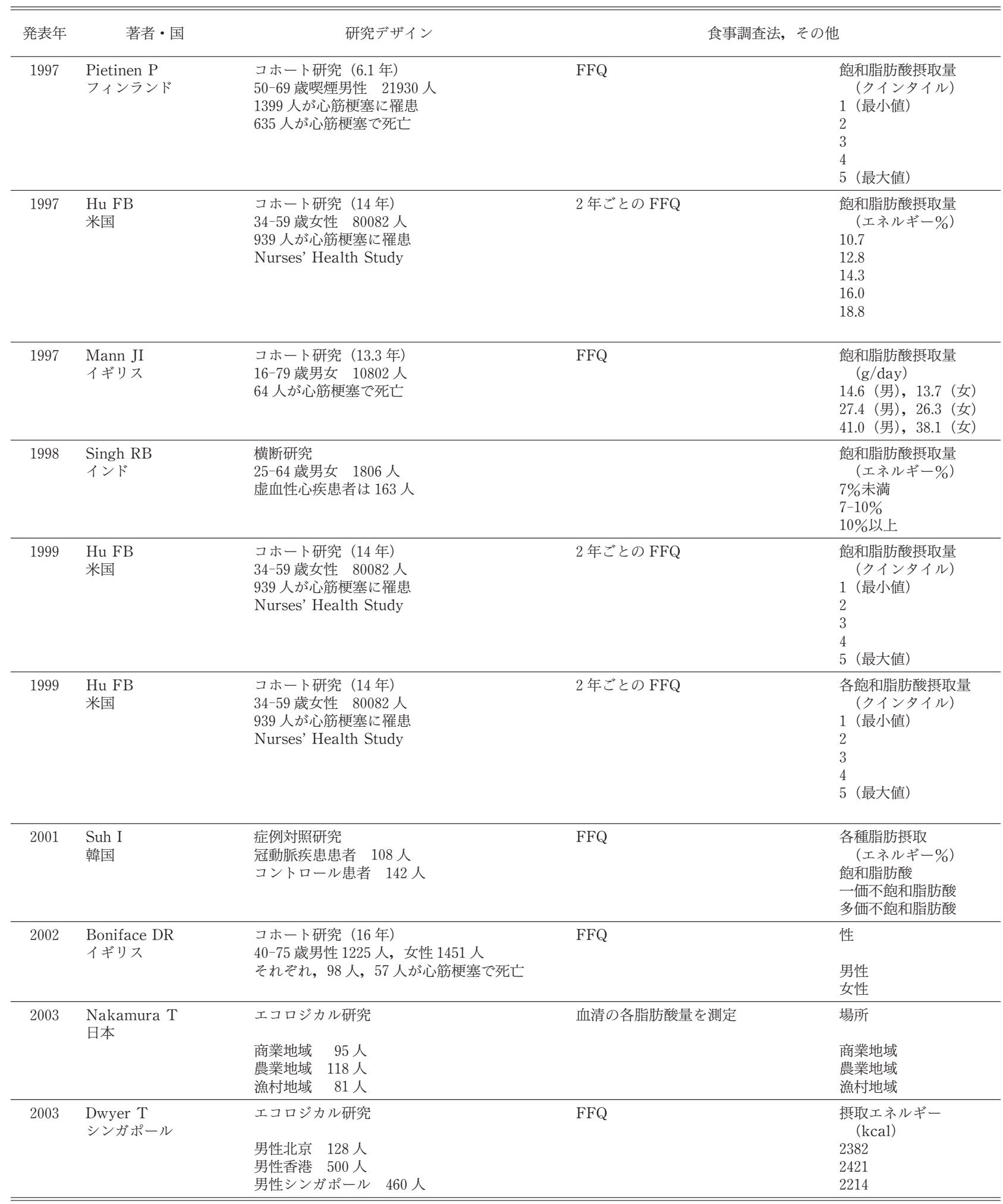

${ }^{1} \mathrm{FFQ}$, Food frequency questionaire.

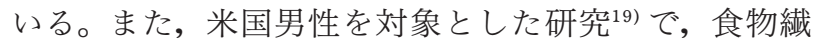
維の補正により飽和脂肪酸の心筋梗塞罹患へのリスクの 消失が認められることから，飽和脂肪酸の摂取量が多い 人は食物繊維が少なく, 食物䋊維の心筋梗塞予防効果に より，見かけ上心筋梗塞の増加が生じている可能性もあ る。正の関連が認められた七つの研究でも相対危険は小
さく，2 倍は越えず大きなリスクにはなっていない。ち なみに喫煙の心筋梗塞の相対危険は 5.5 倍できわめて大 きい27)。

症例対照研究は二つあり, どちらも飽和脂肪酸摂取量

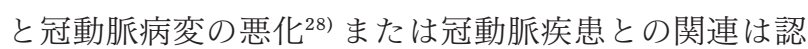
められていない29)。 


\begin{tabular}{|c|c|c|c|c|}
\hline & 結 果 & & コメント & $\begin{array}{l}\text { 文献 } \\
\text { 番号 }\end{array}$ \\
\hline 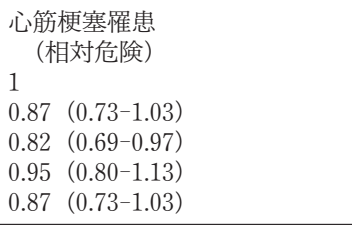 & $\begin{array}{ll}\begin{array}{l}\text { 心筋梗塞死亡 } \\
\quad \text { (相対危険) } \\
1\end{array} \\
0.80(0.63-1.03) \\
0.77(0.60-1.00) \\
0.83 & (0.65-1.07) \\
0.73 & (0.56-0.95) \\
\end{array}$ & & 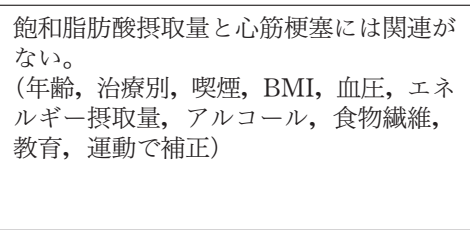 & 20 \\
\hline $\begin{array}{l}\text { 心筋梗塞罹患 } \\
\quad \text { (相対危険, 年齢補正) } \\
1 \\
0.97 \quad(0.79-1.20) \\
1.00(0.81-1.24) \\
1.11 \quad(0.91-1.37) \\
1.38(1.13-1.68)\end{array}$ & 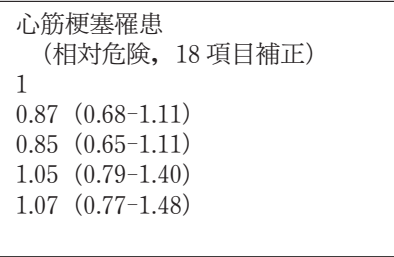 & & 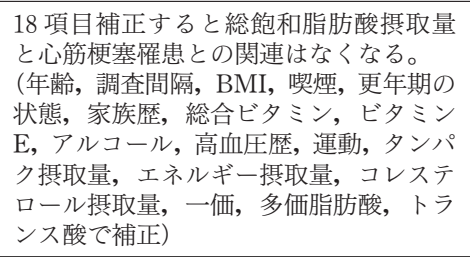 & 21 \\
\hline $\begin{array}{l}\text { 心筋梗塞死亡比率 } \\
\quad \text { \% \% } \\
100 \\
211(94-474) \\
277(125-613)\end{array}$ & & & $\begin{array}{l}\text { 飽和脂肪酸摂取量が多いと心筋梗塞死亡 } \\
\text { が増加。性, 喫煙, 社会地位で補正) } \\
\text { (年齢, }\end{array}$ & 22 \\
\hline $\begin{array}{l}\text { 男性; 虚血性心疾患の人数 } \\
\text { (\%) } \\
4.7 \\
10.6 \\
18.5\end{array}$ & $\begin{array}{l}\text { 女性；虚血性心疾患の人数 } \\
\quad \text { \% } \\
3.3 \\
6.2 \\
12.2\end{array}$ & & $\begin{array}{l}\text { 飽和脂肪酸撖取量が 7\%より多い人は, } \\
\text { 虚血性心疾患が多い。 }\end{array}$ & 30 \\
\hline $\begin{array}{l}\text { Standard multivariate model } \\
\text { (心筋梗塞罹患の相対危険) } \\
1 \\
1.09(0.82-1.44) \\
1.38(0.97-1.95) \\
1.28(0.84-1.95) \\
1.34(0.81-2.21)\end{array}$ & 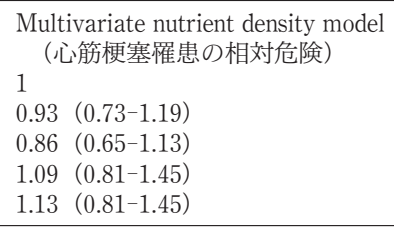 & $\begin{array}{l}18 ： 0 \\
\text { (心筋梗塞罹患の相対危険) } \\
1 \\
0.99(0.77-1.28) \\
0.96(0.72-1.28) \\
1.23(0.90-1.68) \\
1.16(0.81-1.66)\end{array}$ & $\begin{array}{l}\text { 摄取エネルギーと食事調査の頻度, 時期 } \\
\text { 考慮した四つの統計モデルを使用し, } \\
\text { 解析すると, 飽和脂肪酸摈取量と心筇梗 } \\
\text { 塞罹患は弱い正の関連あり。 }\end{array}$ & 23 \\
\hline $\begin{array}{l}\text { C12 : } 0-\mathrm{C} 14: 0 \\
\quad \text { (心筇梗塞罹患の相対危険) } \\
1 \\
0.97(0.78-1.21) \\
0.92(0.73-1.15) \\
1.06(0.85-1.33) \\
1.05(0.83-1.32)\end{array}$ & 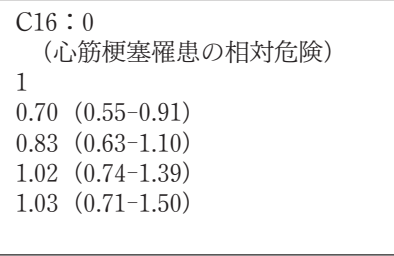 & $\begin{array}{l}18: 0 \\
\text { (心筋梗塞罹患の相対危険 }) \\
1 \\
0.99(0.77-1.28) \\
0.96(0.72-1.28) \\
1.23(0.90-1.68) \\
1.16(0.81-1.66)\end{array}$ & 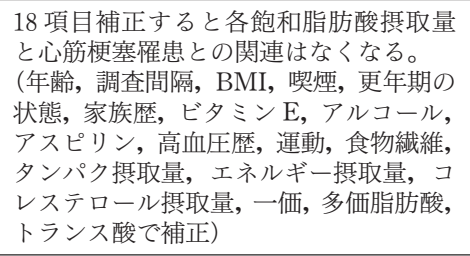 & 24 \\
\hline $\begin{array}{l}\text { Model 1 (BMI, 喫煙, } \\
\text { 総エネルギー摂取量で補正) } \\
1.15(1.02-1.30) \\
1.12(1.01-1.25) \\
1.21(0.97-1.50)\end{array}$ & $\begin{array}{l}\text { Model } 2 \text { (各脂肪酸摂取量を } \\
\text { 追加補正) } \\
1.00(0.81-1.25) \\
0.94(0.75-1.18) \\
0.97(0.72-1.31)\end{array}$ & & $\begin{array}{l}\text { 他の脂肪酸撖取量で補正すると，飽和脂 } \\
\text { 肪酸摂取量と冠動脈疾との関連はなく } \\
\text { なる。 }\end{array}$ & 29 \\
\hline 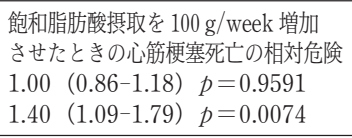 & & & $\begin{array}{l}\text { 女性に於いて飽和脂肪酸増加は心筇梗塞 } \\
\text { 多亡增加と関連。 } \\
\text { (年齢, アルコール, 喫煙, 社会地位で補 } \\
\text { 正) }\end{array}$ & 25 \\
\hline $\begin{array}{l}\text { Myristic }(\mathrm{C} 14: 0) \\
\quad(\mathrm{mg} / \mathrm{L}) \\
23 \\
22.7 \\
16.4\end{array}$ & $\begin{array}{l}\text { palmitic (C16:0) } \\
(\mathrm{mg} / \mathrm{L}) \\
646.7 \\
658.1 \\
548\end{array}$ & $\begin{array}{l}\text { 1994-1998 年の心筇梗塞 } \\
\text { 罹患 (人数/100000 人) } \\
24 \\
30 \\
8 \\
8\end{array}$ & $\begin{array}{l}\text { 漁村では血清飽和脂肪酸量が少なく, 虚 } \\
\text { 血性心疾も少なな。 }\end{array}$ & 33 \\
\hline $\begin{array}{l}\text { 飽和脂肪酸摄取量 } \\
\text { ( }) \\
21 \\
25 \\
31 \\
\end{array}$ & $\begin{array}{l}\text { 心筋梗塞死亡 } \\
\text { (人数/10000 人) } \\
55.6 \\
44.3 \\
108\end{array}$ & & $\begin{array}{l}\text { 飽和脂肪酸の摂取量の多いシンガポール } \\
\text { で筋梗塞死亡が多い。 }\end{array}$ & 34 \\
\hline
\end{tabular}

横断研究 ${ }^{30)}$ では飽和脂肪酸摂取量が 7\%エネルギーよ り多い人では心筋梗塞の増加が認められている。 エコロジカル研究は 4 報告 ${ }^{31-34)}$ あり, どれも飽和脂 肪酸と心筋梗塞との罹患との間に正の相関が認められて いる。日本を含めた，7 カ国コホート研究の結果 ${ }^{31)}$ では 各脂肪酸の中で，飽和脂肪酸と心筋梗塞死亡率の間に用
量依存性の正の相関が認められ，同コホートに含まれた 日本人（2 地域）の心筋梗塞死亡率の低さは飽和脂肪酸 平均摂取量の低さに呼応していた。

介入研究では, 飽和脂肪酸摂取量を減少させると, 心 筋梗塞のマーカー（動脈硬化度，LDL-コレステロール 值など）の数值が減少することを示す報告は多い。心筋 
梗塞罹患自体をエンドポイントにした介入研究35) も一 つあり，乳製品を大豆油に置き換え飽和脂肪酸を半減さ せた食事を 6 年間行うと, 虚血性心疾患罹患の半減が認 められている。冠動脈の動脈硬化の程度をエンドポイン トにした介入研究36)37) も二つあり, 飽和脂肪酸摂取量 が少ないと冠動脈狭窄の軽減を認めている。血中脂質の 変化をエンドポイントとした介入研究も多く行われてい る(表には示さず)。例えば, 欧米諸国での飽和脂肪酸 摂取量をエネルギー比率 10\%エネルギー以下（National Cholesterol Education Program step I diet) または 7\%エネルギー以下（step II diet）にした短期の介入研 究 (1 カ月〜2 年間) のメタアナリシス ${ }^{38)}$ で, 血漿 LDLコレステロール值が低下することが示されている。Step I およびStep II dietでは飽和脂肪酸制限だけでなく, コレステロール摂取量もそれぞれ $300 \mathrm{mg} / \mathrm{day}$ 以下また は $200 \mathrm{mg} /$ day 以下に制限している。このため, Step I およびStep II diet でみられる血漿 LDL-コレステロー ル值の低下はコレステロール摂取量の減少による可能性 もある。しかし，LDL-コレステロール值は食事性コレ スレテロールよりも飽和脂肪酸の影響を強く受けるた め ${ }^{15)}$, Step I および Step II diet の LDL-コレステロー ル值減少効果は飽和脂肪酸摂取量減少のためと考えられ る。

以上のように, コホート研究では多くの交絡変数を考 慮すると, 飽和脂肪酸摂取量と心筋梗塞の罹患の正の関 連は消失するが, 交絡変数を考慮しない場合, 用量依存 性の正の関連が認められる。このことは, 飽和脂肪酸自 体, または飽和脂肪酸を多く摂取する習慣が, 用量依存 性に，心筋梗塞罹患を増加させることを意味する。ま た, 介入研究では飽和脂肪酸摂取量と心筋梗塞罹患また はそのリスクとの正の関連が認められている。これらの 結果から, 飽和脂肪酸摂取量が増加すると, 心筋梗塞罹 患が増加すると考えられる。

\section{3. 肥満 (表 5, 6)}

表 5 に示すように, 14 の横断研究 ${ }^{39-52)}$ があり二つの 研究51)52) を除いて 12 の研究で肥満と飽和脂肪酸摂取量 との間に正の関連が示されている。他の脂肪酸と比較 し, 飽和脂肪酸摂取量とに肥満と正の関連を示す報 告39440)42)43(49-50) も多い。また, 飽和脂肪酸摂取の肥満へ の影響は個人差があり, PPAR $\gamma$ の Ala アレルをもつ たヒトはないヒトよりも飽和脂肪酸摂取により太りやす いことを示す報告 ${ }^{48)}$ もある。しかし，これらの多くの 横断研究では, 肥満の他のリスク, すなわち運動習慣, テレビをみる習慣, 食物繊維などの影響が十分考慮され ていないため, これらの横断研究から飽和脂肪酸の捸取 量増加が原因で肥満を発症すると結論するのは難しい。

表 6 に介入研究53-58) を示す。程度の差はあるが，す べての研究で飽和脂肪酸の減少を含む生活習慣改善は肥 満予防に効果があることを示している。飽和脂肪酸の減 量以外に運動を含めた生活習慣の改善が含まれていて,
たとえ抗肥満効果が認められても, 飽和脂肪酸摂取量減 少による抗肥満効果かどうかは判定できない。しかし， 運動の影響を除いた，欧米諸国での飽和脂肪酸摂取量を 10\%エネルギー以下 (National Cholesterol Education Program step I diet）または7\%エネルギー以下（step II diet）にした多くの短期の介入研究 ${ }^{38)}$ (1 カ月 -2 年間) では, 体重減少を認めている。

動物実験でも飽和脂肪酸の方が肥満しやすいことを示 す報告 ${ }^{59)}$ がある。ラットでは牛脂の方が，サフラワー 油や大豆油に比べて体内の脂肪が付きやすい。この原因 として飽和脂肪酸は他の油に比べて, 交感神経活性化が 起こりにくいことが推定されている60)。マウスでは体重 差はないがパーム油の方が他の油に比べて血中インスリ ン濃度が高くなる ${ }^{61)}$

以上の疫学研究および動物実験から, 飽和脂肪酸を多 く摂取する人は肥満になりやすいことが推定される。

4. 糖 尿 病 (表 7-9)

肥満は糖尿病罹患の最大の危険因子で, BMI35 以上 の人は 23 より少ない人に比べて, 糖尿病になる相対危 険は 40 倍近くになる ${ }^{62)}$ 。飽和脂肪酸摂取の増加は肥満 を生じさせるので糖尿病罹患への関与を考慮する場合, 肥満を介してかどうかが問題となる。表 7 に示すよう に, 五つのコホート研究 ${ }^{64-68)}$ 中, Nurses' Health Study ${ }^{65)}$, Iowa Women's Health Study ${ }^{64)}$, Health Professional Study ${ }^{66)}$ の三つの大規模コホート研究では, BMI で補 正すると飽和脂肪酸摂取と糖尿病罹患との関連は認めら れていない。たとえば, Health Professional Study ${ }^{66)}$ では, 飽和脂肪酸摂取量が $7.6 \%$ エネルギーから $9.6 \%$ エ ネルギーに増加すると, 12 年間での糖尿病の発症率の 相対危険が 1.51 に増加するが BMI で補正すると 1.20 に低下する（図 2)。しかし，飽和脂肪酸摂取量を血漿

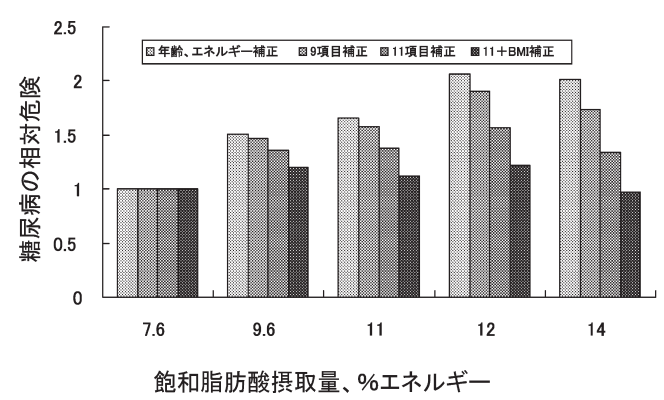

図 2 飽和脂肪酸摂取量と糖尿病罹患との相対危険 (Health Professional Study ${ }^{66)}$ )

約 4 万人の米国男性（40-75 歳）基礎デー夕を 1986 年に取り，その後 2 年ごとに 12 年間の食事内容を 調査し, 飽和脂肪酸摂取量と糖尿病罹患 (1,321 例) の関連を pooled logistic regression 法で調べた。9 項目補正は, 年齢, 総エネルギー摂取量, 期間, 運 動量, 喫煙, 飲酒量, 高コレステロール血症, 高血 圧, 糖尿病の家族歴, 11 項目補正には 9 項目補正に 食物繊維とマグネシウム摂取量が追加され, 12 項目 補正には 11 項目補正に BMI が追加されている。 
表 5 肥満（観察研究）

\begin{tabular}{|c|c|c|c|c|c|c|c|c|c|c|c|c|c|}
\hline \multirow{2}{*}{$\begin{array}{l}\text { 発表年 } \\
1991\end{array}$} & \multirow{2}{*}{$\begin{array}{l}\text { 著者・国 } \\
\text { Maron DJ } \\
\quad \text { 米国 }\end{array}$} & \multicolumn{5}{|c|}{ 対象・方法 } & \multicolumn{5}{|c|}{ 結 } & \multirow[b]{2}{*}{$\begin{array}{l}\text { 飽和脂肪酸の摂取 } \\
\text { 量と BMI おょび } \\
\text { ウエスト-ヒップ } \\
\text { 比に正の相関が観 } \\
\text { 察された。 }\end{array}$} & \multirow[t]{2}{*}{$\begin{array}{l}\text { 文献 } \\
\text { 番号 } \\
\end{array}$} \\
\hline & & $\begin{array}{l}\text { 横断研究 } \\
\text { 非糖尿病で冠動脈 } \\
\text { 疾患のある患者 } \\
215 \text { 人, } 32-74 \text { 歳, } \\
\text { 食 事, 身体パラ } \\
\text { メター調査 }\end{array}$ & $\begin{array}{l}4 \text { 日間食事記録 } \\
\text { エネルギー\% } \\
\text { 総脂肪 } \\
\text { 飽和脂肪酸 } \\
\text { モノ不飽和脂肪酸 } \\
\text { 多価不飽和脂肪酸 } \\
\text { 総カロリー (kcal) }\end{array}$ & \multicolumn{3}{|c|}{$\begin{aligned} & 31.9(8.0-54.0) \\
& 10.0(2.2-22.1) \\
& 12.0(2.2-23.2) \\
& 7.5(2.2-19.3) \\
& 2075(638-3739) \\
&\end{aligned}$} & $\begin{array}{l}\text { 相関 } \\
\text { 総脂肪 } \\
\text { 飽和脂肪酸 } \\
\text { モノ不飽和 } \\
\text { 多価不飽和 }\end{array}$ & 脂肪酸 & $\begin{array}{r}\text { BMI } \\
0.12 \\
0.18 \\
0.10 \\
-0.04\end{array}$ & \multicolumn{2}{|c|}{$\begin{array}{c}\text { ウエスト-ヒップ比 } \\
0.18 \\
0.21 \\
0.13 \\
0.04\end{array}$} & & \\
\hline 1993 & $\begin{array}{l}\text { Mayer EJ } \\
\text { 米国 }\end{array}$ & $\begin{array}{l}\text { 横断研究 } \\
544 \text { 人 女性 } \\
\text { 食事脂肪摂取とイ } \\
\text { ンスリン, 体脂 } \\
\text { 肪\%, ウエスト- } \\
\text { ヒップ比などとの } \\
\text { 相関を調査 }\end{array}$ & $\begin{array}{l}\text { 食品摂取頻度調査 } \\
\text { 平均データ } \\
\text { 総キロカロリー } \\
\text { 総脂肪 }(\mathrm{g}) \\
\text { 飽和脂肪 }(\mathrm{g}) \\
\text { オレイン酸 }(\mathrm{g}) \\
\text { リノール酸 }(\mathrm{g})\end{array}$ & \multicolumn{3}{|c|}{$\begin{array}{r}1511.7 \\
64.5 \\
21.9 \\
23.8 \\
12.9 \\
\end{array}$} & \multicolumn{2}{|c|}{$\begin{array}{l}\text { 部分的相関係数 } \\
\text { 総食事脂肪 } \\
\text { 飽和脂肪酸 } \\
\text { モノ不飽和脂肪酸 } \\
\text { 多価不飽和脂肪酸 }\end{array}$} & $\begin{array}{c}\text { 体脂肪\% } \\
0.07 \\
0.09 \\
0.06 \\
0.07\end{array}$ & $\begin{array}{l}\text { BMI } \\
0.09 \\
0.09 \\
0.07 \\
0.11\end{array}$ & $\begin{array}{l}\text { ウエスト- } \\
\text { ヒップ比 } \\
0.05 \\
0.07 \\
0.09 \\
0.01\end{array}$ & $\begin{array}{l}\text { 高脂肪摂取が絶食 } \\
\text { 時高インスリン血 } \\
\text { 症と関連した。飽 } \\
\text { 和脂肪酸と肥満イ } \\
\text { ンデックスは正の } \\
\text { 相関である。 }\end{array}$ & 40 \\
\hline 1994 & $\begin{array}{l}\text { Ward KD } \\
\text { 米国 }\end{array}$ & $\begin{array}{l}\text { 横断研究 } \\
878 \text { 人 男性 } \\
\text { 食事飽和脂肪, 高 } \\
\text { インスリン血症, } \\
\text { 内臟肥満の関連を } \\
\text { 調查 }\end{array}$ & \multicolumn{4}{|c|}{$\begin{array}{l}\text { 半定量的食品摂取頻度調査 } \\
\text { 平均データ } \\
\text { 飽和脂肪酸（g/day） } \\
\text { 総カロリー }\end{array}$} & \multicolumn{5}{|c|}{$\begin{array}{ll}\text { 飽和脂肪酸との相関 } & \\
\mathrm{BMI} & 0.20 \\
\text { 腹部-ヒップ比 } & 0.13\end{array}$} & $\begin{array}{l}\text { 飽和脂肪酸の摂取 } \\
\text { 量とBMI お方び } \\
\text { 腹部-ヒップ比, } \\
\text { インスリンレ゙ルル } \\
\text { との間に正の相関 } \\
\text { が観察された。 }\end{array}$ & 41 \\
\hline 1994 & $\begin{array}{c}\text { Obarzanek E } \\
\text { 米国 }\end{array}$ & $\begin{array}{l}\text { 横断研究 } \\
2379 \text { 人の少女 } \\
(9-10 \text { 歳) } \\
\text { 食事, 運動, 肥満 } \\
\text { の関係調查 }\end{array}$ & $\begin{array}{l}3 \text { 日間食事記録 } \\
\text { エネルギー }(\mathrm{kcal}) \\
\text { 総脂肪 }(\mathrm{g}) \\
(\text { エネルギー\%) } \\
\text { 飽和脂肪 } \\
(\text { エネルギー\%) }\end{array}$ & $\begin{array}{l}\text { 人少 } \\
1856 \\
76.2 \\
36.7\end{array}$ & 女 白 & $\begin{array}{l}\text { 白人少女 } \\
1805 \\
70.7 \\
35.1 \\
\\
13.7\end{array}$ & \multicolumn{2}{|c|}{$\begin{array}{l}\text { 多重回帰相関 } \\
\text { 黒人少女 } \\
\text { 飽和脂肪酸 } \\
\text { (エネルギー\%) } \\
\text { 白人少女 } \\
\text { 総脂肪 } \\
\text { (エネルギー\%) }\end{array}$} & $\begin{array}{l}\text { BMI } \\
0.13\end{array}$ & 3 力 & $\begin{array}{l}\text { 所皮脂厚計 } \\
0.40\end{array}$ & $\begin{array}{l}\text { 飽和脂肪酸の攝取 } \\
\text { 量と体脂肪に関 } \\
\text { 連。 }\end{array}$ & 42 \\
\hline 1995 & $\begin{array}{l}\text { Posner BM } \\
\text { 米国 }\end{array}$ & $\begin{array}{l}\text { コホート研究 } \\
\text { フラミンガムスタ } \\
\text { ディ } \\
1966-1969 \\
\quad 47-65 \text { 歳 } 865 人 \\
1984-1988 \\
37-70 \text { 歳 } 1602 \text { 人 }\end{array}$ & \multicolumn{4}{|c|}{$\begin{array}{l}\text { 1966-1969 } 24 \text { 時間思い出し法 } \\
\text { 1984-1988 } 24 \text { 時間思い出し法, 食習 } \\
\text { 慣調査, 半定量的食品摂取頻度調査, } 3 \\
\text { 日間食事記録 }\end{array}$} & \multicolumn{2}{|c|}{$\begin{array}{l}\text { 脂肪（エネルギー％) } \\
\text { 飽和脂肪酸 } \\
\text { (エネルギー） } \\
\text { 過体重（\%) } \\
\text { 身体活動 }\end{array}$} & \multicolumn{2}{|c|}{$\begin{array}{c}1966-1969 \\
47-65 \text { 歳 } \\
39.4 \\
16.4 \\
\\
33.7 \\
34.3\end{array}$} & $\begin{array}{l}\text { 生 } \\
1984-1988 \\
37-70 \text { 歳 } \\
38.4 \\
17.0 \\
\\
40.2 \\
35.4\end{array}$ & $\begin{array}{l}\text { 1966-1969 年に比 } \\
\text { 較して,1984-1988 } \\
\text { 年では飽和脂肪酸 } \\
\text { 摂取エネルギー\% } \\
\text { が増加している。 } \\
\text { 過体重者\%も増加 } \\
\text { している。 }\end{array}$ & 163 \\
\hline 1996 & $\begin{array}{l}\text { Larson DE } \\
\quad \text { 米国 }\end{array}$ & $\begin{array}{l}\text { 横断研究 } \\
135 \text { 人白人男性 } \\
214 \text { 人白人女性 } \\
\text { 食事脂肪摂取と肥 } \\
\text { 満パラメー夕調查 }\end{array}$ & \multicolumn{4}{|c|}{$\begin{array}{l}3 \text { 日間食事記録 } \\
\text { エネルギー ( } \mathrm{kJ} / \text { day) } \\
\text { エ総脂肪 }(\mathrm{kJ} / \mathrm{day}) \\
(\text { エネルギー\%) } \\
\text { 飽和脂肪 }(\mathrm{kJ} / \mathrm{day}) \\
(\text { エネルギー\%) }\end{array}$} & \multicolumn{2}{|c|}{$\begin{array}{l}\text { 飽和脂肪酸 } \\
(\mathrm{kJ} / \mathrm{day}) \\
\text { 多価不飽和脂肪酸 } \\
(\mathrm{kJ} / \mathrm{day})\end{array}$} & $\begin{array}{r}\text { 回帰 } \\
0.00 \\
-0.0\end{array}$ & $\begin{array}{l}\text { 高モデル } \\
\text { ルギーf } \\
\text { 㷌係数 } \\
.0058 \\
.0038\end{array}$ & $\begin{array}{c}\text { (除脂肪体 } \\
\text { 取取で補正) } \\
r^{2} \\
0.025 \\
0.007\end{array}$ & $\begin{array}{l}\text { 除脂肪体重, 性, } \\
\text { 身体活動, 除脂肪 } \\
\text { エネルギー搙取で } \\
\text { 補正したモデルで, } \\
\text { 飽和脂肪酸は体脂 } \\
\text { 肪重量と正の相関 } \\
\text { を示した。一方, } \\
\text { 多価不飽和脂肪酸 } \\
\text { は体脂肪重量と負 } \\
\text { の相関を示した。 }\end{array}$ & 43 \\
\hline 1997 & $\begin{array}{c}\text { Kafatos A } \\
\text { ギリシャ }\end{array}$ & $\begin{array}{l}\text { コホート }(30 \text { 年間 }) \\
\text { 男性 }(40-59 \text { 歳 }) \\
\text { 体重 }(n=177) \\
\text { BMI }(n=177)\end{array}$ & \multicolumn{4}{|c|}{$\begin{array}{l}1960 \text { 年 } \\
\quad 7 \text { 日間食事重量記録 } \\
(n=31) \\
1991 \text { 年 } \\
3 \text { 日間食事重量記録 } \\
(n=21)\end{array}$} & \multicolumn{2}{|c|}{$\begin{array}{l}1960 \text { 年 } \\
\text { 体重 }(\mathrm{kg}) \quad 64.5 \\
\mathrm{BMI}\left(\mathrm{kg} / \mathrm{m}^{2}\right) \quad 24 \\
\text { 飽和脂肪酸摂取 } \\
\text { モノ不飽和脂肪酸摂取 }\end{array}$} & \multicolumn{3}{|c|}{$\begin{array}{l}1991 \text { 年 } \\
\quad \text { 体重 }(\mathrm{kg}) \quad 69.4 \\
\text { BMI } \quad\left(\mathrm{kg} / \mathrm{m}^{2}\right) \quad 25.7 \\
+25 \% \\
\quad-20.7 \%\end{array}$} & $\begin{array}{l}30 \text { 年間で, 飽和脂 } \\
\text { 肪酸摂 取量の増 } \\
\text { 加, モノ不飽和脂 } \\
\text { 肪酸攝取量の減少 } \\
\text { が 認められその } \\
\text { 間, 体 重およひび } \\
\text { BMI が増加。 }\end{array}$ & 164 \\
\hline 1997 & $\begin{array}{l}\text { Porkka KV } \\
\text { フィンランド }\end{array}$ & $\begin{array}{l}15 \text { 歳と } 18 \text { 歳のと } \\
\text { きの食事, 身体パ } \\
\text { ラメータ, 血清脂 } \\
\text { 質パラメータを } \\
\text { 年ごとに調査 } \\
1980 \text { 年 } 3517 \text { 人 } \\
1983 \text { 年 } 2769 \text { 人 } \\
1986 \text { 年 } 2392 \text { 人 } \\
1989 \text { 年 } 352 \text { 人 } \\
1992 \text { 年 } 880 \text { 人 }\end{array}$ & $\begin{array}{l}48 \text { 時間思い出し法 } \\
\text { データ } \\
\text { 総エネルギー } \\
\text { (kcal) } \\
\text { 総脂肪 } \\
\text { (エネルギー\%) } \\
\text { 飽和脂肪酸 } \\
\text { (g/1000 kcal) } \\
\text { モノ不飽和脂肪酸 } \\
\text { (g/1000 kcal) } \\
\text { 多価不飽和脂肪酸 } \\
\text { (g/1000 kcal) }\end{array}$ & $\begin{array}{l}38.4 \\
21.9\end{array}$ & \begin{tabular}{l|} 
开究年 \\
1986 \\
2380 \\
38.4 \\
21.1 \\
15.0
\end{tabular} & $\begin{array}{r}1992 \\
2216 \\
36.3 \\
18.1 \\
14.5 \\
6.7\end{array}$ & \multicolumn{2}{|l|}{ データ } & $\begin{array}{r}1980 \\
60.0 \\
20.8 \\
\\
6.6 \\
9.5 \\
11.3\end{array}$ & $\begin{array}{r}\text { 研究年 } \\
1986 \\
61.9 \\
21.1 \\
\\
6.2 \\
9.4 \\
10.8\end{array}$ & $\begin{array}{r}1992 \\
65.1 \\
21.8 \\
\\
6.5 \\
10.8 \\
12.3\end{array}$ & $\begin{array}{l}\text { 1980-1992 年で, } \\
\text { 飽和脂肪酸摂取量 } \\
\text { は減 少した だ } \\
\text { BMI は高くなっ } \\
\text { た。運動不足が原 } \\
\text { 因か。 }\end{array}$ & 165 \\
\hline 1998 & $\begin{array}{l}\text { Singh RB } \\
\text { インド }\end{array}$ & $\begin{array}{l}\text { 横断研究 } \\
904 \text { 人男性 } \\
902 \text { 人女性 }(25-64 \\
\text { 歳) } \\
\text { 飽和脂肪酸エネル } \\
\text { ギー\%により } \\
\text { very low } \quad<7 \% \\
\text { low } \quad 7-10 \% \\
\text { high } \quad>10 \%\end{array}$ & $\begin{array}{lr}7 \text { 日間食事摂取記録 } \\
\text { データ } \\
\\
\text { 総エネル } \\
\text { 男性 } \\
\text { 女性 }\end{array}$ & $\begin{array}{l}\text { ギー } \\
\text { kcal/ }\end{array}$ & $\begin{array}{l}\text { 飽和月 } \\
\text { lay) } \\
2 \\
2\end{array}$ & 脂肪酸 & $\begin{array}{l}\text { 男性 } \\
\text { very low } \\
\text { low } \\
\text { high } \\
\text { 女性 } \\
\text { very low } \\
\text { low } \\
\text { high }\end{array}$ & $\begin{array}{l}<7 \% \\
7-10 \% \\
>10 \% \\
<7 \% \\
7-10 \% \\
>10 \%\end{array}$ & $\begin{array}{l}20.1 \\
22 . \\
24 .\end{array}$ & $\begin{array}{l}8 \\
.1 \\
8\end{array}$ & & $\begin{array}{l}\text { 飽和脂肪酸エネル } \\
\text { ギー捸取が高い群 } \\
\text { で, B M I は高 } \\
\text { かった。7エネル } \\
\text { ギー\%以下が良 } \\
\text { い。 }\end{array}$ & 44 \\
\hline
\end{tabular}


表 5 つづき

\begin{tabular}{|c|c|c|c|c|c|c|c|c|c|c|}
\hline 発表年 & 著者・国 & & 対象・方法 & & & & 結 & 果 & & $\begin{array}{l}\text { 文献 } \\
\text { 番号 }\end{array}$ \\
\hline 1997 & $\begin{array}{l}\text { Alfieri M } \\
\text { カナダ }\end{array}$ & $\begin{array}{l}\text { 横断研究 } \\
\text { 以下三づラグルー } \\
\text { プの脂肪摂取量調 } \\
\text { 查 } \\
\text { 正常体重 } 50 \text { 名 } \\
\text { BMI : } 20.0-27.0 \\
\text { 軽度肥満 } 50 \text { 名 } \\
\text { BMI : } 27.1-39.9 \\
\text { 重度肥満 } 50 \text { 名 } \\
\text { BMI : } 40.0-\end{array}$ & \multicolumn{3}{|l|}{3 日間食事記録 } & \multicolumn{3}{|c|}{ 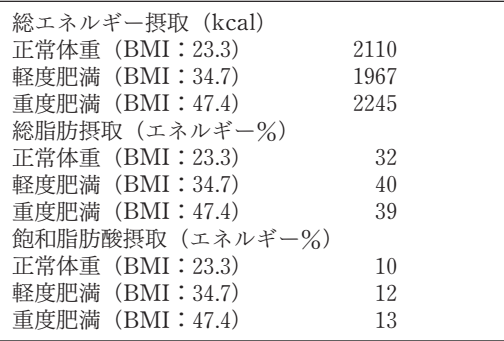 } & $\begin{array}{l}\text { 総エネルギー捸取 } \\
\text { 量に差はない。総 } \\
\text { 脂肪, 飽和脂肪 } \\
\text { 酸, モノ不飽和脂 } \\
\text { 肪酸, 多価不飽和 } \\
\text { 脂肪酸のエネル゙ } \\
\text { ギー\%が肥満群で } \\
\text { 高い。 }\end{array}$ & 45 \\
\hline 2000 & $\begin{array}{c}\text { Gonzalez CA } \\
\text { スペイン }\end{array}$ & $\begin{array}{l}\text { 横断研究 } \\
\text { 女性 } 23289 \text { 人 } \\
\text { 男性 } 14374 \text { 人 }\end{array}$ & \multicolumn{3}{|l|}{$\begin{array}{l}\text { 食事暦アンケート } \\
\text { 重回帰分析 }\end{array}$} & \multicolumn{2}{|c|}{$\begin{array}{l}\text { BMI } \\
\text { 飽和脂肪酸 (\%エネルギー) } \\
\text { モノ不飽和脂肪酸 } \\
\text { 多価不飽和脂肪酸 }\end{array}$} & \begin{tabular}{cr}
\multicolumn{2}{c}{ 回帰係数 } \\
女性 & \multicolumn{1}{c}{ 男性 } \\
0382 & -0.0151 \\
0368 & 0.0763 \\
1040 & 0.0942 \\
\end{tabular} & $\begin{array}{l}\text { BMI と飽和脂肪 } \\
\text { 酸, モノ不飽和脂 } \\
\text { 肪酸, 多価不飽和 } \\
\text { 脂肪酸摂取量の関 } \\
\text { 連は小さい。 }\end{array}$ & 46 \\
\hline 2001 & $\begin{array}{c}\text { Brunner EJ } \\
\text { 英国 }\end{array}$ & $\begin{array}{l}\text { 横断研究 } \\
4497 \text { 人 男性, } \\
1865 \text { 人 女性 } \\
39-62 \text { 歳 }\end{array}$ & $\begin{array}{l}\text { 半定量的食事摂取頻度言 } \\
7 \text { 日間食事記録 } \\
\text { データ } \\
\text { 総エネルギー } \\
\text { 総脂肪 }(\mathrm{g}) \\
\text { 飽和脂肪 }(\mathrm{g}) \\
\text { 多価飽和脂肪 }(\mathrm{g}) \\
\text { モノ飽和脂肪 (g) }\end{array}$ & $\begin{array}{r}\text { 調査 } \\
\\
\text { 男性 } \\
2381 \\
86.6 \\
35.2 \\
18.0 \\
28.9\end{array}$ & $\begin{array}{r}\text { 女性 } \\
2015 \\
75.4 \\
31.1 \\
15.3 \\
24.8\end{array}$ & $\begin{array}{l}\text { 相関係数 (エネルギ } \\
\text { 男性 } \\
\text { 総脂肪 } \\
\text { 飽和脂肪 } \\
\text { 多価不飽和脂肪 - } \\
\text { モノ不飽和脂肪 } \\
\text { 女性 } \\
\text { 総脂肪 } \\
\text { 飽和脂肪 } \\
\text { 多価不飽和脂肪 }\end{array}$ & $\begin{array}{l}\text { ギー撖取補正) } \\
\text { BMI ウエ } \\
0.00 \\
0.01 \\
-0.03 \\
0.02 \\
\\
0.05 \\
0.03 \\
0.06\end{array}$ & $\begin{array}{c}\text { ストーヒップ比 } \\
\\
0.00 \\
0.02 \\
-0.06 \\
0.02 \\
\\
0.05 \\
0.02 \\
0.0\end{array}$ & $\begin{array}{l}\text { BMI とウエスト- } \\
\text { ヒップ比に対し } \\
\text { て, 飽和脂肪は小 } \\
\text { さな正相関を示し } \\
\text { た。 }\end{array}$ & 47 \\
\hline 2001 & $\begin{array}{l}\text { Luan J } \\
\text { 英国 }\end{array}$ & $\begin{array}{l}\text { 横断研究 } \\
\text { PPAR } \gamma \text { アレル別 } \\
\text { に効果を比較 } \\
592 \text { 人非糖尿病被 } \\
\text { 験者 } \\
\text { PPAR } 2 \text { 2, Pro } 12 A l a \\
\text { Ala ホモ: } 2.0 \% \\
\text { Pro/Ala } 18.9 \% \\
\text { Pro ホモ: } 79.1 \% \\
\text { Pro ホモに対し } \\
\text { て,Alaアレル } \\
\text { キャリアを比較 }\end{array}$ & 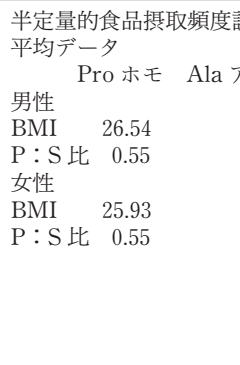 & $\begin{array}{r}\text { 調查 } \\
\text { アレルキ } \\
26.7 \\
0.56 \\
25.7 \\
0.56\end{array}$ & ヤリア & \multicolumn{3}{|c|}{$\begin{array}{lr}\text { 回㷌係数 } & \\
\text { 年齢 } & \text { BMI } \\
\text { 性 } & 0.050 \\
\text { PPAR } \gamma & 0.629 \\
\mathrm{P}: \mathrm{S} \text { 比 } & -2.412 \\
\mathrm{P}: \mathrm{S} \text { 比 } \times \text { PPAR } \gamma & -4.320 \\
\text { ただし, Ala ア } & 4.366 \\
\text { 1 とコードした。 } & \end{array}$} & 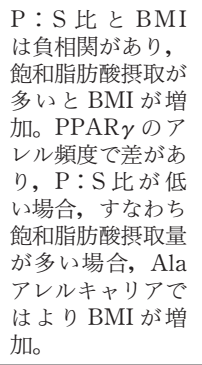 & 48 \\
\hline 2001 & $\begin{array}{c}\text { Mayer-Davis } \\
\text { EJ 米国 }\end{array}$ & $\begin{array}{l}\text { 横断研究 } \\
675 \text { 人正常耐糖能 } \\
\text { 被験者 } \\
332 \text { 人耐糖能異常 } \\
\text { 被験者 } \\
\text { 食事脂肪摂取と肥 } \\
\text { 満, インスリンの } \\
\text { 関連調查 }\end{array}$ & $\begin{array}{l}\text { 半定量的食事攝取頻度言 } \\
\text { データ } \\
\text { 総エネルギー }(\mathrm{kcal}) \\
\text { 総脂肪 }(\mathrm{g}) \\
\text { 飽和脂肪 }(\mathrm{g}) \\
\text { 多価飽和脂肪 }(\mathrm{g}) \\
\text { モノ飽和脂肪 }(\mathrm{g})\end{array}$ & $\begin{array}{r}\text { 調査 } \\
\text { 男性 } \\
2381 \\
86.6 \\
35.2 \\
18.0 \\
28.9\end{array}$ & $\begin{array}{r}\text { 女性 } \\
2015 \\
75.4 \\
31.1 \\
15.3 \\
24.8\end{array}$ & $\begin{array}{l}\text { 相関係数 } \\
\text { 脂肪 (\%) } \\
\text { 飽和脂肪 (\%) } \\
\text { 多価飽和脂肪（\%) } \\
\text { オレイン酸（\%) }\end{array}$ & \begin{tabular}{rl}
\multicolumn{2}{c}{ BMI } \\
NGT & IGT \\
0.10 & 0.15 \\
0.10 & 0.12 \\
0.08 & 0.11 \\
0.07 & 0.13
\end{tabular} & \begin{tabular}{lr}
\multicolumn{2}{c}{ ウエスト長 } \\
NGT & IGT \\
0.09 & 0.04 \\
0.09 & 0.03 \\
0.01 & -0.00 \\
0.10 & 0.05
\end{tabular} & $\begin{array}{l}\text { 飽和脂肪酸は, } \\
\text { BMI, ウエスト長 } \\
\text { と正相関。 }\end{array}$ & 49 \\
\hline 2001 & $\begin{array}{l}\text { Garaulet M } \\
\text { スペイン }\end{array}$ & $\begin{array}{l}\text { 横断研究 } \\
85 \text { 人 の肥満被験 } \\
\text { 者 ( } 30 \text { 人男性, } 55 \\
\text { 人女性, } 30-70 \text { 歳, } \\
\text { BMI } 27-35) \\
\text { 肥満因子分析 }\end{array}$ & 7 日間食事記録 & & & $\begin{array}{l}\text { 因子分析 } \\
\text { 脂質 } \\
\text { エネルギー } \\
\text { 飽和脂肪酸 } \\
\text { タンパク質 } \\
\text { モノ不飽和脂肪酸 } \\
\text { コレステロル } \\
\text { 炭水化物 } \\
20: 4 n 6 \\
16: 0 \\
18: 0\end{array}$ & $\begin{array}{l}\text { F1 } \\
0.94 \\
0.93 \\
0.91 \\
0.88 \\
0.88 \\
0.87 \\
0.72 \\
0.63\end{array}$ & $\begin{array}{r}\mathrm{F} 2 \cdots \\
\\
\\
\\
\\
\\
\\
0.93 \\
0.93\end{array}$ & $\begin{array}{l}\text { 食事の影響が変動 } \\
\text { の } 40 \% \text { 以上に } \\
\text { たり, 脂質エネル } \\
\text { ギー, 飽和脂肪酸 } \\
\text { の摂取の影響が観 } \\
\text { 察された。 }\end{array}$ & 50 \\
\hline 2001 & $\begin{array}{l}\text { Ramos de } \\
\text { Marins VM } \\
\text { ブラジル }\end{array}$ & $\begin{array}{l}\text { 横断研究 } \\
1455 \text { 人男性, } \\
1906 \text { 人女性 } \\
2 \text { 段階, ランダム } \\
\text { サンプリング調査 }\end{array}$ & $\begin{array}{l}\text { 半定量的食品摂取頻度言 } \\
\text { データ } \\
\text { エネルギー摂取 }>2500 \\
\text { 脂肪摂取エネルギー>3 } \\
\text { 飽和脂肪エネルギー>1 }\end{array}$ & & $\begin{array}{l}55.2 \% \\
31.1 \% \\
42.3 \%\end{array}$ & $\begin{array}{l}\text { オッズ比 } \\
\text { エネルギー摂取 } \\
>2500 \\
\leqq 2500 \\
\text { 脂肪消費エネルギー } \\
>30 \% \\
\leqq 30 \\
\text { 飽和脂肪消費エネル } \\
>10 \% \\
\leqq 10\end{array}$ & $\begin{array}{l}\text { BMI ウエ } \\
\text {-\% } \\
1.0 \\
1.0 \\
1.0\end{array}$ & $\begin{array}{c}\text { ストーヒップ比 } \\
1.0 \\
1.0\end{array}$ & $\begin{array}{l}\text { エネルギー, 脂肪 } \\
\text { 消費エネルギー\%, } \\
\text { 飽和脂肪消費エネ } \\
\text { ルギー\% } \% \text { BMI } \\
\text { やウエスト-ヒッ } \\
\text { プ比のオッズ比は } \\
1.0 \text { であった。 }\end{array}$ & 51 \\
\hline 2002 & $\begin{array}{l}\text { Trichopoulou A } \\
\text { ギリシャ }\end{array}$ & $\begin{array}{l}\text { 横断研究 } \\
27862 \text { 人の健康な } \\
\text { ボランティア }\left(25^{-}\right. \\
82 \text { 歳 })\end{array}$ & $\begin{array}{l}\text { 半定量的食物摂取頻度 } \\
\text { 重回㷌分析 } \\
\text { 年齢, 教育, 喫煙, 工 } \\
\text { 栄養素間相互調整 }\end{array}$ & $\begin{array}{l}\text { 調查 } \\
\text { ネルギ }\end{array}$ & —消費, & $\begin{array}{l}\text { BMI } \\
\text { タンパク質 } \\
\text { 炭水化物 } \\
\text { 飽和脂肪酸 } \\
\text { 多価不飽和脂肪酸 } \\
\text { モノ不飽和脂肪酸 } \\
\text { エタノール }\end{array}$ & $\begin{array}{c}\text { 栄養素間相互 } \\
\text { 男性 } \\
0.80 \\
-0.09 \\
-0.18 \\
0.13 \\
0.03\end{array}$ & $\begin{array}{c}\text { 調整回帰係数 } \\
\text { 女性 } \\
1.59 \\
-0.26 \\
-0.81 \\
0.56 \\
0.12\end{array}$ & $\begin{array}{l}\text { タンパク摂取量と } \\
\text { BMI とは正の関 } \\
\text { 連が認められた } \\
\text { が,一価不飽和脂 } \\
\text { 肪酸, 飽和脂肪酸 } \\
\text { のどちらも BMI } \\
\text { の上昇の主要な役 } \\
\text { 割は果たしていな } \\
\text { いようである。 }\end{array}$ & 52 \\
\hline
\end{tabular}


表 6 肥満（介入研究）

\begin{tabular}{|c|c|c|c|c|c|c|c|c|c|c|c|}
\hline \multirow{2}{*}{$\begin{array}{l}\text { 発表年 } \\
1997\end{array}$} & \multirow[b]{2}{*}{$\begin{array}{c}\text { 著者・国 } \\
\text { Agurs-Collins } \\
\text { TD 米国 }\end{array}$} & \multicolumn{5}{|c|}{ 対象・方法 } & \multicolumn{3}{|c|}{ 結＼cjkstart果 } & \multirow[b]{2}{*}{$\begin{array}{l}\text { 介入群で, } 3 \text { 力月, } \\
6 \text { 力月の体重減少 } \\
\text { が観察された。介 } \\
\text { 入群の } 3 \text { カ月で脂 } \\
\text { 肪エネルギーの減 } \\
\text { 少, 飽和脂肪エネ } \\
\text { ルギーの減少が観 } \\
\text { 察された。 }\end{array}$} & \multirow[b]{2}{*}{$\begin{array}{l}\text { 文献 } \\
\text { 番号 } \\
\\
\\
\\
\\
\\
\\
\end{array}$} \\
\hline & & $\begin{array}{l}\text { 過体重アフリカン-アメリ } \\
\text { カン } 64 \text { 人 } \\
55-79 \text { 歳非インスリン依存 } \\
\text { 性糖疛病 } \\
\text { ランダム化 } \\
\text { 介入群 }(12 \text { 週間グループ } \\
\text { セッション, } 1 \text { 個人 セッ } \\
\text { ション, } 6 \text { 隔 週 グ ループ } \\
\text { セッション) } \\
\text { 通常ケア群 }(1 \text { クラス, } 2 \text { 情 } \\
\text { 報郵便 }) \\
0,3,6 \text { カフて臨床検査, 活 } \\
\text { 動調查介入群は運動と食事 } \\
\text { 療法の両方。 }\end{array}$ & $\begin{array}{l}1 \text { 週間食品担 } \\
\text { データ } \\
\text { kcal } \\
\text { 介入 } \\
\text { 対照 } \\
\text { 脂肪エネルキ } \\
\text { 介入 } \\
\text { 対照 } \\
\text { 飽和脂肪エ } \\
\text { 介入 } \\
\text { 対照 }\end{array}$ & $\begin{array}{r}\text { ベー取頻度 } \\
\text { ベース } \\
1488 \\
1398 \\
\text { ギー\% } \\
32 \\
29 \\
\text { ネルギー } \\
10 \\
9\end{array}$ & 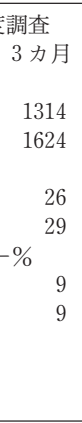 & $\begin{array}{r}6 \text { カ月 } \\
1560 \\
1696 \\
\\
27 \\
27 \\
\\
9 \\
8\end{array}$ & $\begin{array}{l}\text { 体重 }(\mathrm{kg}) \\
\text { 介入 } \\
\text { 対照 } \\
\mathrm{BMI} \\
\text { 介入 } \\
\text { 対照 } \\
\text { ウェストーヒップ比 } \\
\text { 介入 } \\
\text { 対照 }\end{array}$ & $\begin{array}{l}90.8 \\
96.2 \\
\\
33.1 \\
34.9 \\
\\
0.94 \\
0.92\end{array}$ & $\begin{array}{l}33.1 \\
35.8 \\
0.94 \\
0.92\end{array}$ & & \\
\hline 1999 & $\begin{array}{l}\text { Eriksson J } \\
\text { フィンランド }\end{array}$ & $\begin{array}{l}513 \text { 人の過体重, 耐糖能異 } \\
\text { 常者 } \\
\text { ランダム化 } \\
\text { 介入 最初の } 1 \text { 年に } 7 \text { セッ } \\
\text { ション, } 3 \text { カ月ごとの訪問, } \\
\text { 体重減少, 飽和脂肪摂取減 } \\
\text { 少, 食物繊維摂取増加を目 } \\
\text { 的とした。身体活動を増加 } \\
\text { させるようにガイドした。 } \\
\text { 最初の } 212 \text { 人のみのデータ }\end{array}$ & 3 日間食事䚶 & 钎録 & & & $\begin{array}{l}\text { ベースライン } \\
\text { BMI } \\
\text { 脂肪重量 }(\mathrm{kg}) \\
1 \text { 年後 } \\
\text { BMI } \\
\text { 脂肪重量 }(\mathrm{kg}) \\
\text { 体重変化 }(\mathrm{kg})\end{array}$ & $\begin{array}{l}\text { 个入群 } \\
\\
31.3 \\
30.3 \\
\\
29.6 \\
27.9 \\
-4.7\end{array}$ & $\begin{array}{r}\text { 対照群 } \\
\\
31.1 \\
30.2 \\
\\
30.8 \\
29.8 \\
-0.9\end{array}$ & $\begin{array}{l}1 \text { 年間の介入によ } \\
\text { り，体重がより低 } \\
\text { 下した。食事デー } \\
\text { タの詳細は不明。 }\end{array}$ & 54 \\
\hline 2001 & $\begin{array}{l}\text { Tuomilehto J } \\
\text { フィンランド }\end{array}$ & 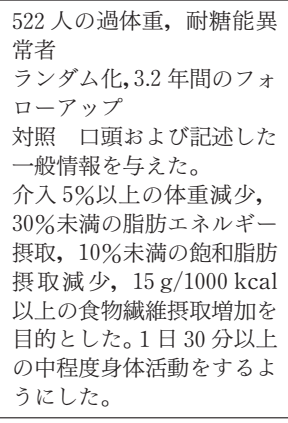 & $\begin{array}{l}3 \text { 日間食事訕 } \\
\text { デー夕 } \\
\text { 脂肪消費減 } \\
\text { 脂肪の質変 }\end{array}$ & & $\begin{array}{l}87 \% \\
70 \%\end{array}$ & $\begin{array}{l}70 \% \\
39 \%\end{array}$ & $\begin{array}{l}\text { ベースライン } \\
\text { BMI } \\
\text { ウエスト長 }(\mathrm{cm}) \\
1 \text { 年後 } \\
\quad \text { 体重変化 }(\mathrm{kg}) \\
\quad \text { ウエスト長変化 }(\mathrm{cm}) \\
\text { 体重減少 > } 5 \% \\
\text { 脂肪エネルギー摂取 < } 3009\end{array}$ & $\begin{array}{c}\text { 介入群 } \\
\\
31.3 \\
102.0 \\
\\
-4.2 \\
-4.4 \\
43 \% \\
6 \quad 47 \%\end{array}$ & $\begin{array}{r}\text { 対照群 } \\
\\
31.0 \\
100.5 \\
\\
-0.8 \\
-1.3 \\
13 \% \\
26 \%\end{array}$ & $\begin{array}{l}1 \text { 年間の介入によ } \\
\text {, 体重が } 4.2 \mathrm{~kg} \\
\text { 減少, 非介入では } \\
0.8 \mathrm{~kg} \text { の減少に留 } \\
\text { まる。 }\end{array}$ & 55 \\
\hline 2001 & $\begin{array}{c}\text { Kriketos } \mathrm{AD} \\
\text { 米国 }\end{array}$ & $\begin{array}{l}52 \text { 人の中程度肥満被験者 } \\
\text { 第 } 1 \text { 期ベースライン } 1 \text { 週間 } \\
\text { ランダム化 } \\
\text { 第 } 2 \text { 期 食事介入 } 10 \text { 週 } \\
\text { 間, 食事エネルギー制限 } \\
\text { 女性 } 1200 \mathrm{kcal} \text {, 男性 } 1800 \\
\mathrm{kcal} \\
\text { 飽和脂肪酸群 } \\
\text { オメガ } 3 \text { 脂肪酸群 } \\
\text { オメガ } 6 \text { 脂肪酸群 } \\
\text { 第 } 3 \text { 期 } 4 \text { 週間体重維持期 } \\
\text { 間 }\end{array}$ & $\begin{array}{l}\text { 代謝研究キ, } \\
18 \% \text { タン, } \\
32 \% \text { 脂肪 } \\
50 \% \text { 炭水 } \\
\text { 飽和脂肪酸君 } \\
\text { オメガ } 3 \text { 脂 } \\
25 \% \text { オメ } \\
\text { オメガ } 6 \text { 脂 } \\
25 \% \text { オメン }\end{array}$ & $\begin{array}{l}\text { ッチンに } \\
\text { パク質 } \\
\text { 化物 } \\
\text { 群: } \mathrm{P} / \mathrm{S} \\
\text { 昌肪酸君 } \\
\text { ガ } 3 \text { 脂肪 } \\
\text { 肪 酸君 } \\
\text { ガ } 6 \text { 脂肪 }\end{array}$ & $\begin{array}{l}\text { こより食 } \\
\\
\mathrm{S}=0.25 \\
\text { 群: P/S } \\
\text { 方酸 } \\
\text { 群 : P } / \mathrm{S} \\
\text { 方酸 }\end{array}$ & $\begin{array}{l}\text { 事供給 } \\
=1.0, \\
=1.0,\end{array}$ & \begin{tabular}{cc}
\multicolumn{3}{c}{ 飽和脂肪酸 } \\
体重 (kg) & \\
第1 期 & 98.08 \\
第 2 期 & 88.17 \\
第 3 期 & 86.98 \\
体脂肪 (\%) & \\
第 1 期 & 42.24 \\
第 2 期 & 37.05 \\
第3 期 & 36.01
\end{tabular} & $\begin{array}{l}\text { メガ } 3 \\
91.68 \\
83.85 \\
83.12 \\
\\
41.52 \\
38.33 \\
36.85\end{array}$ & $\begin{array}{l}\text { オメガ } 6 \\
\\
95.41 \\
85.64 \\
85.22 \\
\\
41.57 \\
37.98 \\
37\end{array}$ & $\begin{array}{l}\text { 体脂肪減少に関し } \\
\text { ては, カロリー制 } \\
\text { 限の効果が強く脂 } \\
\text { 肪酸の違いは, マ } \\
\text { イナーだった。 }\end{array}$ & 56 \\
\hline 2002 & $\begin{array}{c}\text { Summers LK } \\
\text { 英国 }\end{array}$ & $\begin{array}{l}17 \text { 人 } \\
6 \text { 人夕イプ II 糖尿病 } \\
6 \text { 人非肥満者 } \\
5 \text { 人肥満者 } \\
\text { 飽和脂肪酸食, 多価不飽和 } \\
\quad \text { 脂肪酸食 } \\
5 \text { 週 間 } 2 \text { 回, クロス オー } \\
\quad \text { バーデザイン } \\
\quad\end{array}$ & 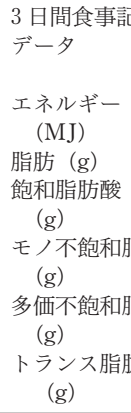 & $\begin{array}{l}\text { 録 } \\
\text { ベース } \\
10.4 \\
102 \\
\\
36.0 \\
\text { 脂肪酸 } \\
35.2 \\
\text { 脂肪酸 } \\
16.8 \\
\text { 肪酸 } \\
3.7\end{array}$ & $\begin{array}{r}\text { SFA } \\
10.6 \\
117 \\
58.7 \\
33.9 \\
9.8 \\
3.0\end{array}$ & $\begin{array}{r}\text { PUFA } \\
8.9 \\
80 \\
20.1 \\
24.3 \\
21.7 \\
1.4\end{array}$ & 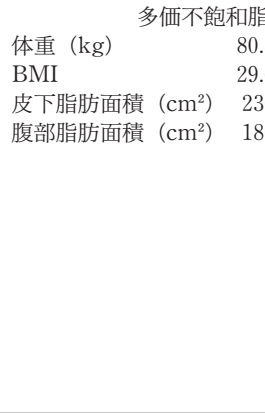 & $\begin{array}{l}\text { 肪酸 } \\
8 \\
6 \\
0 \\
0\end{array}$ & $\begin{array}{l}\text { 絇和脂肪酸 } \\
\quad 81.2 \\
29.7 \\
330 \\
180\end{array}$ & $\begin{array}{l}\text { 体重やBMI } \text { ○対 } \\
\text { する脂肪酸の影響 } \\
\text { は小さいようで } \\
\text { あった。皮下脂肪 } \\
\text { 面積は, 多価不飽 } \\
\text { 和脂肪酸群で, 飽 } \\
\text { 和脂肪酸群と比較 } \\
\text { して減少した。イ } \\
\text { ンスリン感受性 } \\
\text { は, 多価不飽和脂 } \\
\text { 肪酸群で, 飽和脂 } \\
\text { 肪酸群と比較して } \\
\text { 改善した。 }\end{array}$ & 57 \\
\hline 2003 & $\begin{array}{l}\text { Lindstrom J } \\
\text { フィンランド }\end{array}$ & $\begin{array}{l}522 \text { 人の過体 重 }(\mathrm{BMI}> \\
25) \text {, 耐糖能異常者 } \\
\text { ランダム化 } \\
\text { 対照 口頭および記述した } \\
\text { 一般情報を与えた。 } \\
\text { 介入 } 5 \% \text { 以上の体重減少, } \\
30 \% \text { 未満の脂肪エネルギー } \\
\text { 摂取, } 10 \% \text { 未満の飽和脂肪 } \\
\text { 摂 取減少, } 15 \mathrm{~g} / 1000 \mathrm{kcal} \\
\text { 以上の食物緘維摂取増加を } \\
\text { 目的とした。。 } \\
\text { の中程度身体活動をするよ } 30 \text { 分以上 } \\
\text { うにした。 }\end{array}$ & $\begin{array}{l}3 \text { 日間食事訪 } \\
\text { データ } \\
\text { 脂肪消費減少 } \\
\text { 脂肪の質変 }\end{array}$ & & $\begin{array}{l}87 \% \\
70 \%\end{array}$ & $\begin{array}{l}70 \% \\
39 \%\end{array}$ & $\begin{array}{l}\text { ベースライン } \\
\text { BMI } \\
\text { ウェスト長 }(\mathrm{cm}) \\
1 \text { 年後 } \\
\quad \text { 体重変化 }(\mathrm{kg}) \\
\text { ウェスト長変化 }(\mathrm{cm}) \\
2 \text { 年後 } \\
\text { 体重変化 }(\mathrm{kg}) \\
\text { ウェスト長変化 }(\mathrm{cm})\end{array}$ & $\begin{array}{r}\text { 个入群 } \\
\\
31.3 \\
102.0 \\
-4.2 \\
-4.4 \\
-3.5 \\
-4.2\end{array}$ & $\begin{array}{r}\text { 対照群 } \\
\\
31.0 \\
100.5 \\
-0.8 \\
-1.3 \\
\\
-0.8 \\
-1.3\end{array}$ & $\begin{array}{l}\text { 介入により, } 1 \text { 年 } \\
\text { 後および } 2 \text { 年後の } \\
\text { 体重, ウエスト長 } \\
\text { がより減少した。 }\end{array}$ & 58 \\
\hline
\end{tabular}


表 7 糖尿病（観察研究）

\begin{tabular}{|c|c|c|c|c|c|}
\hline 発表年 & 著者・国 & 対象・方法 & 結 & 果 & 文献番号 \\
\hline 1990 & $\begin{array}{l}\text { Feskens EJ } \\
\text { オランダ }\end{array}$ & 50-70 歳の非糖尿病 394 名を用いた横断調査。 & $\begin{array}{l}\text { 空腹時血糖値と飽和脂肪酩 } \\
\text { た。総茨取熱量, 肩甲骨 } 7 \\
\text { この関連は認められた。 }\end{array}$ & $\begin{array}{l}\text { 七の間には正の相関関係を認め } \\
\text { 女下脂肪厚，年齢で補正しても }\end{array}$ & 166 \\
\hline
\end{tabular}

1994 Fujimoto WY 横断調査および 5 年間の追跡調査。45-74 歳の日 米国系 2 世 420 例抒よび 34-54 歳の 3 世男性 238 例。

2 世男性の横断調查：糖尿病例では IGT, 正常と比較し, 総 摂取熱量は変わらないが, 動物性脂肪, タンパクの攝取量 が多かった（動物性脂肪 DM/IGT/N(\%) : 34.0/31.8/

\begin{tabular}{|c|c|c|}
\hline 1995 & $\begin{array}{c}\text { Feskens EJ } \\
\text { フィンランド, } \\
\text { オランダ }\end{array}$ & $\begin{array}{l}\text { コホート研究。 50-69 歳時に食事調查を実施し, } 20 \\
\text { 年後糖負荷試験を行った非糖氺病男性 } 338 \text { 名 (正 } \\
\text { 常型の食事内容 } 3474 \mathrm{kcal} \text {, 脂肪熱量比 : } 38.7 \% \text {, } \\
\text { countires Study。 }\end{array}$ \\
\hline
\end{tabular}

2001 Harding AH 40-78 歳の非糖尿病男性 2759 名扔よび女性 3464 英国名の地域住民を対象とした横断調査（男性および 女性の総熱量摂取量 : 2206 と $1937 \mathrm{kcal}$, 脂肪熱 量比：33 と $32 \%$, 飽和： 12.9 と $12.2 \%$, 多価 6.0 と $5.9 \%$, タンパク熱量比：16 と $17 \%) 。$

\begin{tabular}{ccl}
\hline 2001 & Meyer KA & コホート研究。 $55-69$ 歳の女性で糖尿病でない \\
米国 & 35988 人を対象。127 食品の FFQ, 生活習慣調査を \\
& 1986 年に行い, 11 年間観察。1 890 人が糖疗病を \\
& 発症。Iowa Women's Health Study。
\end{tabular}

2001 Salmeron J コホート研究。34-59歳の女性で糖尿病でない 米国 84,204 人を対象。FFQ, 生活習慣調査を最初 1980 年に行い, その後 2 年ごとに調査, 14 年間観察し, 2507 人が糖尿病を発症。Nurses' Health Study。

$\begin{array}{ccc}2002 & \text { van Dam RM } & \text { コホート研究。 } 40-75 \text { 歳の非糖尿病男性 } 42504 \text { 名 } \\ \text { 米国 } & \text { を } 12 \text { 年間追跡し, 栄養捸取と糖尿病との関係を }\end{array}$ 検討。Health Professional Study。

\begin{tabular}{|c|c|c|}
\hline 2002 & 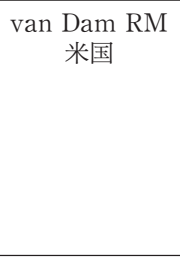 & 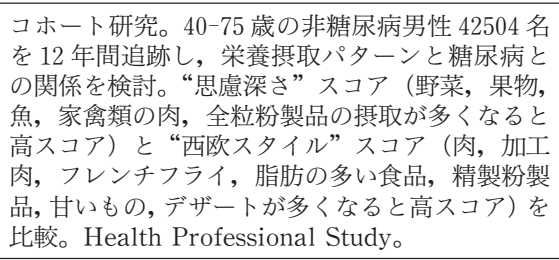 \\
\hline 2003 & $\begin{array}{l}\text { Wang L } \\
\text { 米国 }\end{array}$ & $\begin{array}{l}\text { コホート研究。 } 45-64 \text { 歳の } 2909 \text { 名の血漿中のコ } \\
\text { レステロールエステルょよ゙リン脂質の脂肪酸組 } \\
\text { 成を調べた後, } 9 \text { 年間追跡し, 糖尿病発症との関 } \\
\text { 係を検討。ARIC Study。 }\end{array}$ \\
\hline
\end{tabular}
31.3, (g) : 41.3/30.9/33.9, (\%kcal) : 17.1/13.7/14.2)。ま た追跡調査で IGT から糖尿病を発症した例では, 総摂取熱 量 $(p<0.05)$, 動物性脂肪 $(p<0.01)$, コレステロール $(p<0.05)$ 攝取量が多かった。

20 年後 71 例に IGT, 26 例に糖尿病が見出された。糖尿病 発症例では, 正常あるいはIGT と比較し, 20 年前の総脂 肪, 飽和脂肪酸, 一価不飽和脂肪酸抒よびコレステロール 摂取量が高值であった（BMI で補正せず）。年齢，過去の BMI, 過去の総摂取熱量調整後, 負荷後 2 時間血糖值と飽 和脂肪酸摂取量との間には正の相関関係があった。

$\mathrm{HbAlc}$ は, 年齢, 性を調整後, 多価不飽和脂肪酸/飽和脂 肪酸比 ( $\mathrm{P}: \mathrm{S}$ 比) と負の, 総脂肪摂取量と正の相関関係に あった。この関係は, 扔互い, および総熱量, タンパク摂 取量, 年齢, 性, 糖尿病家族歴, BMI, ウエスト・ヒップ 比, 身体活動量, 喫煙で調整後も認められた。

飽和脂肪酸摄取量と糖尿病罹患には 13 項目 (BMI, 運動, 食物繊維を含む) で補正すると関連は認められない。植物 油と糖尿病と有意の負の相関 $(p<0.001)$ 。飽和脂肪酸を植 物油に置き換えると 5 分位で相対危険は $1.0,0.92 ， 0.89$, 0.83 , and $0.84(p=0.02)$ と有意差あり。Keys dietary score と関連あり。

飽和脂肪酸摂取量と糖尿病罹患には BMI と年齢で補正 すると関連は認められない。多価不飽和脂肪酸摄取量と糖 尿病と有意の負の相関 $(p<0.0002)$ 。トランス脂肪酸摂取 量と糖尿病と有意の正の相関 $(p<0.0002)$ 。コレステロー ル摂取量と糖尿病と有意の正の相関 $(p<0.0001)$ 。

12 年間に 1321 例が糖尿病を発症。総脂肪および飽和脂肪 酸摂取量の多さが糖尿病発症と関係したが, BMI を調整す ると有意ではなくなった。< 65 歳ではリノール酸の摂取は 糖尿病の発症抑制に, また全年齢で加工肉製品の搨取頻度 の多さは糖尿病発症の危険因子であった。

12 年間に 1321 例が糖尿病を発症。糖尿病発症の頻度は, “思慮深さ”スコアとは逆相関, 食事に扔ける“西欧ス夕イ ル”スコアとは正相関した。食事における“西欧スタイル” スコア高値に身体活動量低值あるいは肥満が重複すると, 糖尿病発症はきわめて高頻度となる。

9 年間の追跡中 252 例で糖尿病を発症。糖尿病発症率とコ レステロールエステルおよびリン脂質中の飽和脂肪酸組成 比との間に, 年齢, 性, BMI, ウエスト・ヒップ比, アル コール摂取量, 喫煙, 身体活動量, 教育歴, 両親に抒ける 糖尿病の有無を調整後, 有意の関係が認められた。リン脂 質中の $\mathrm{C} 16: 0$ と $\mathrm{C} 18: 0$ と糖尿病の罹患との間氾相関 あり。

表 8 糖尿病（介入研究）

\begin{tabular}{|c|c|c|c|c|}
\hline 発表年 & 著者・国 & 対象・方法 & 結 & 文献番号 \\
\hline 2001 & $\begin{array}{l}\text { Tuomilehto J } \\
\text { フィンランド }\end{array}$ & 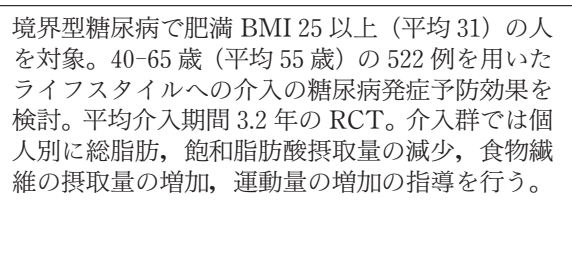 & 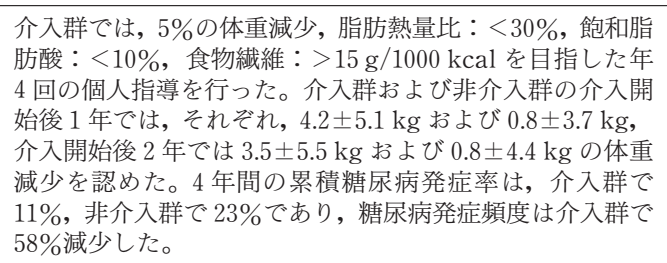 & 69 \\
\hline 2003 & $\begin{array}{l}\text { Lindström J } \\
\text { フィンランド }\end{array}$ & $\begin{array}{l}\text { 40-65 (平均 55) 歳の BMI }>25 \text { (平均 31) の } 522 \\
\text { 例の境界型糖尿病を対象とし, ライフスタイル } \\
\text { の介入と粮病発症との関係について検討した } \\
\text { RCT (平均介入期間 } 3.2 \text { 年)。 }\end{array}$ & 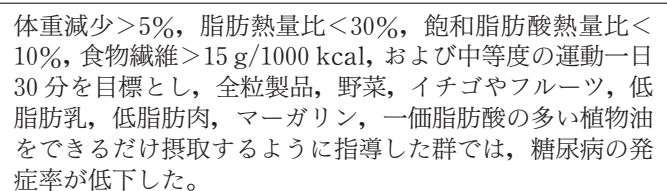 & 70 \\
\hline
\end{tabular}


表 9 インスリン抵抗性

\begin{tabular}{|c|c|c|c|c|}
\hline 発表年 & 著者・国 & 対象・方法 & 結 & 文献番号 \\
\hline 1991 & $\begin{array}{l}\text { Maron DJ } \\
\text { 米国 }\end{array}$ & $\begin{array}{l}32-74 \text { 歳の冠動脈撮影で冠動脈疾患と } \\
\text { 診断された非糖尿病 } 215 \text { 列を対象とし } \\
\text { た横断調査。 }\end{array}$ & 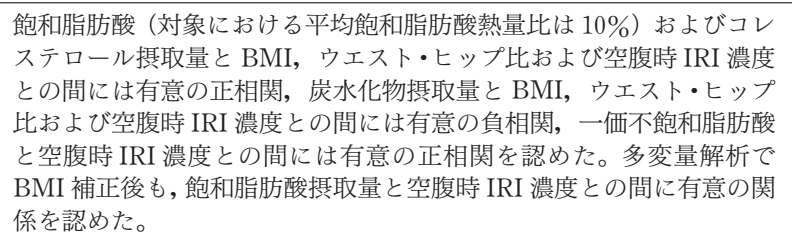 & 71 \\
\hline 1993 & $\begin{array}{l}\text { Mayer EJ } \\
\text { 米国 }\end{array}$ & $\begin{array}{l}\text { 30-84 (平均 51) 歳の非糖尿病双生児 } \\
\text { 女性 } 544 \text { 名を対象とした横断調査 (平 } \\
\text { 均攝取熱量 }: 1512 \mathrm{kcal} \text {, 脂肪 }: 64.5 \mathrm{~g} \text {, } \\
\text { 脂肪熱 量 比 : } 37.6 \% \text { )。Kaiser Per- } \\
\text { manente Women Twins Study。 }\end{array}$ & 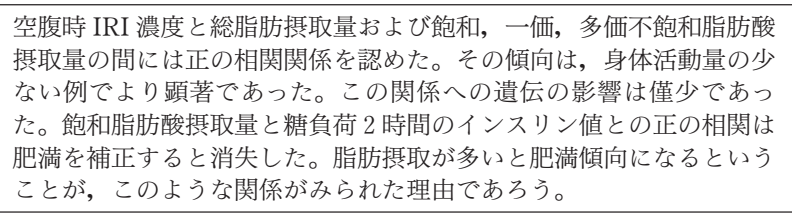 & 72 \\
\hline 1994 & $\begin{array}{c}\text { Feskens EJ } \\
\text { オランダ }\end{array}$ & $\begin{array}{l}\text { 70-89 歳の非糖尿病男性 } 389 \text { 例を対象 } \\
\text { として横断調査にて, 食事, 身体活動 } \\
\text { 量と高インスリン血症との関係を検 } \\
\text { 討。Zutphen Elderly Study。 }\end{array}$ & 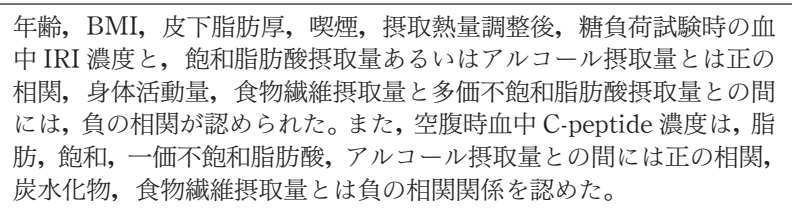 & 73 \\
\hline 1996 & $\begin{array}{l}\text { Fasching P } \\
\text { オーストリア }\end{array}$ & $\begin{array}{l}1 \text { 週間の介入研究。 } 26.3 \pm 3.5 \text { 歳, BMI } \\
22.4 \pm 1.8 \text { の健常者 } 8 \text { 例を対象に炭水 } \\
\text { 化物, 飽和,一価, 多価不飽和脂肪酸 } \\
\text { に富む食事のインスリン感受性および } \\
\text { 脂肪酸化への影響を無作為化クロス } \\
\text { オーバー試験で検討。 }\end{array}$ & 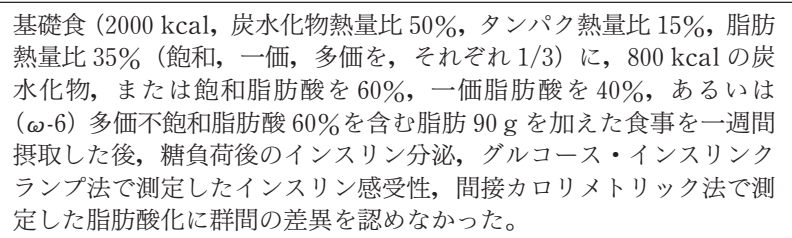 & 77 \\
\hline 1997 & $\begin{array}{l}\text { Marshall JA } \\
\quad \text { 米国 }\end{array}$ & $\begin{array}{l}20-74 \text { 歳の正常耐糖能 } 1069 \text { 名を対象 } \\
\text { として, 横断調査にて飽和脂肪酸, 澱 } \\
\text { 粉と食物緘維摂取量と血中 IRI 濃度と } \\
\text { の関係を検討。San Luis Valley } \\
\text { Diabetes Study。 }\end{array}$ & 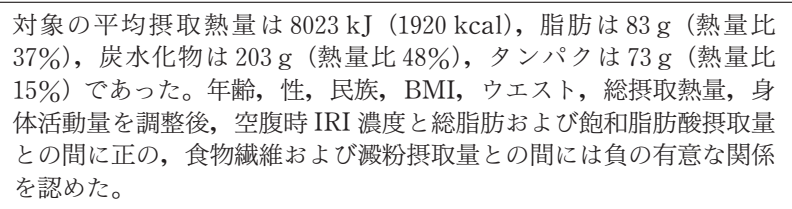 & 74 \\
\hline 2001 & $\begin{array}{c}\text { Vessby B } \\
\text { スウェーデン }\end{array}$ & $\begin{array}{l}3 \text { カ月の介入研究。30-65 歳の BMI } \\
22-32 \text { の } 162 \text { 例を対象とした無作為化 } \\
\text { 群間比較試験。飽和脂肪酸に富む食事 } \\
\text { と一価不飽和脂肪酸に富む食事の } 3 \text { 力 } \\
\text { 月の摂取と, } 1 \text { 日 } 3.6 \mathrm{~g} \text { の } n \text { 不飽和脂 } \\
\text { 肪酸 }(2.4 \mathrm{~g} \mathrm{EPA} / \mathrm{DHA}) \text { 投与の影響を } \\
\text { 検討。 }\end{array}$ & 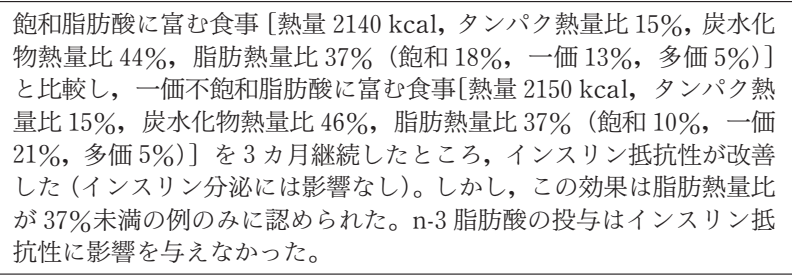 & 75 \\
\hline 2001 & $\begin{array}{c}\text { Perez-Jimenez F } \\
\text { スペイン }\end{array}$ & $\begin{array}{l}28 \text { 日間の介入研究。30 歳以下の } 52 \text { 名 } \\
\text { (平均年齢 } 23 \text { 歳, BMII 22.9)を対象と } \\
\text { した無作為化クロスオーバー試験。 } 28 \\
\text { 日ごとと食事内容を変更し糖代謝への } \\
\text { 影響を検討。 }\end{array}$ & 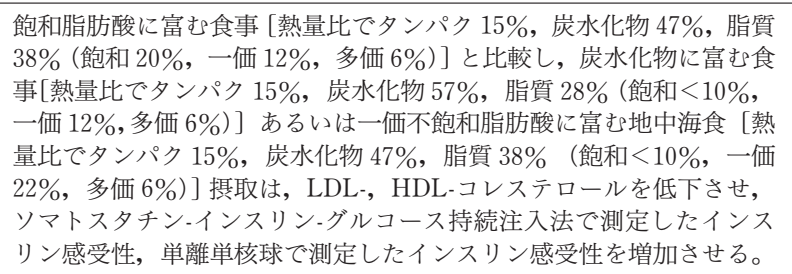 & 76 \\
\hline 2002 & $\begin{array}{l}\text { Lovejoy JC } \\
\text { 米国 }\end{array}$ & $\begin{array}{l}4 \text { 週間の介入研究。2 } 28 \pm 2 \text { 歳, BMI } \\
23.5 \pm 0.5(18 \text { 例 }<25,7 \text { 例 } 25-30) \text { の } \\
\text { 健常者 } 25 \text { 例を対象に飽和, 一価不飽 } \\
\text { 和, トランス脂肪酸に富む食事のインン } \\
\text { スリン感受性㧍よび脂肪酸化への影響 } \\
\text { を無作為化, 二重盲検, クロスオー } \\
\text { バー試験で検討。 }\end{array}$ & 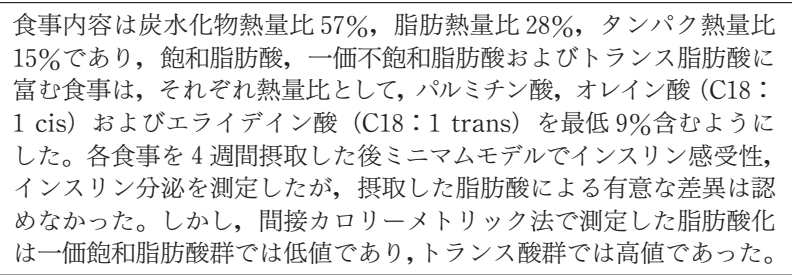 & 78 \\
\hline
\end{tabular}

中の脂肪酸量で推定した研究 ${ }^{67)}$ では，血漿中コレステ ロールエステルとリン脂質の飽和脂肪酸組成比が高い群 で，BMI などで補正しても，9 年間の観察期間に糖尿 病の発症率の増加が認められている。日系米男性を対象 とした研究68) では, 動物性脂肪を多く摂取した群で, BMI は変化しないが, 内臓脂肪量が増加し, 糖尿病発 症率の増加が認められている。しかし, 内臓脂肪量で補
正後の結果は示されていない。

介入研究69970) (表 8）も二つ報告されているが，飽和 脂肪酸量の減少のみならず，運動量なども増加させてい るため, 飽和脂肪酸自体の効果かどうか明らかでない。

糖尿病罹患の原因の一つであるインスリン抵抗性をエ ンドポイントにして，飽和脂肪酸摂取量との関連を調心゙ た横断研究71-74) もある (表 9)。四つのすべての横断研 
究で飽和脂肪酸摂取量が増加するとインスリン抵抗性を 生じている (正の関連)。BMI 補正後でも飽和脂肪酸捸 取量とインスリン抵抗性の正の関連が三つの研究71)73174) で認められている。介入研究も四つ報告がある。二つの 研究75576) で飽和脂肪酸はインスリン抵抗性を生じたが, 短期間および飽和脂肪酸量の少ない介入研究 ${ }^{77) 78)}$ では 変化を認めていない。これらの介入研究では体重変化は みられていないので，体重補正は行われていない。

これらの結果は, 飽和脂肪酸の増加により肥満とな り, 肥満した結果, 糖尿病罹患が増加することを示唆し ている。しかし，飽和脂肪酸摂取は，肥満とは独立して インスリン抵抗性を生じ, インスリン抵抗性を介して糖 尿病を発症させている可能性もある。

\section{5. 脳 卒 中（表 10）}

脳卒中の観察研究は日本人を対象にした研究6)79-81) が いくつかある。

脳出血（脳実質内出血であり，くも膜下出血は除く） に関しては, 日本人の 40-69 歳男女を対象にしたコホー 卜研究81) で, 飽和脂肪酸摂取量と負の関連が認められ ている。図 3 に示すように用量依存性であり, 飽和脂肪 酸の摂取量が少ないと, 交絡変数（血圧，肥満度，コレ ステロール值，喫煙，アルコール摂取量）を考慮して も, 脳出血罹患率の増加が認められている。飽和脂肪酸 の摂取量と脳出血罹患とは $p$ for trend $=0.005$ と強い関 連が認められるのに対し, 動物性タンパク質摂取量と脳 出血罹患とは $p$ for trend $=0.14$ で関連は認められず, 飽和脂肪酸の方が動物性タンパク質より, 脳出血罹患へ の影響は大きいと考えられる ${ }^{81)}$ 。広島, 長崎在住の中年 男性 1,366 人を 1972 年に登録し, 4 年間での脳出血（臨 床症状から診断）の罹患を調べた研究 ${ }^{79)}$ (Ni-Hon-San Study）でも， $5 \mathrm{~g} /$ day 未満で脳出血罹患の増加を認め

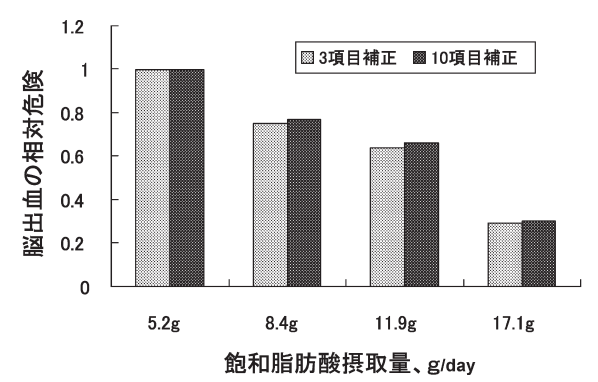

図 3 飽和脂肪酸捸取量と脳出血との相対危険 ${ }^{81)}$ 約 5 千人の日本人（40-69 歳）基礎データを 1984 年までに得，24 時間思い出し法により，食事摂取 量を推定した。このコホートでは 1997 年までに 14 年間に 68 例の脳内出血による脳卒中を認めた。飽 和脂肪酸摂取量との関連を調べるため, 交絡変数の 影響が除けるCox proportional hazards model で 分析した。3 項目補正には, 年齢, 性, 地域, 10 項 目補正には, 年齢, 性, 総エネルギー摂取量, BMI, 高血圧, 糖尿病, 血中コレステロール值, 喫煙, 飲酒量, 更年期の状態が含まれる。
ている。米国女性でも飽和脂肪酸が少ないと脳出血の増 加が認められ, 飽和脂肪酸摂取量と脳出血罹患とはU 型を示し, $25 \mathrm{~g} /$ day の摂取量で脳出血罹患が最も少な くなっている ${ }^{82)}$ 。しかし, 米国男性では飽和脂肪酸摂取 量を 17，21，24，26，31 gの五つのカテゴリーに分け た場合, 各群で脳出血罹患に差は認められていない覀。

脳梗塞に関しては, 日本人 ${ }^{80)}$ では飽和脂肪酸摂取量 との関連は認められていないが，米国の Framingham Heart Study ${ }^{84)}$ では負の相関が認められている。

1965-1968 年に登録を始めたハワイ在住の 45 歳以上 の男性日系人を対象としたコホート研究6)では, 飽和脂 肪酸の摂取量が $10 \mathrm{~g} /$ day 未満だと, 10 年間の脳卒中死 亡率が急増し, $10 \mathrm{~g} /$ day 以上の約 2 倍になることを認 めている (図 4)。しかし, この研究では脳出血と脳梗 塞は区別されていない。

以上の結果から, 飽和脂肪酸摂取量が少ないと脳出血 罹患が増加することを示唆する。

\section{6. 乳 が $ん$ (表 11)}

Key word 検索により, コホート研究を 7 報見出し, その中で負の関連を認めた報告 ${ }^{85)}$ は 1 報, 関連なしの 報告 ${ }^{86-91)}$ が 6 報あった。症例対照研究は 13 報あり, 正 の関連を認めた報告 ${ }^{92-96)}$ が 5 報, 関連なしの報告 ${ }^{97-104)}$ が 8 報あった。メタアナリシスも 4 報あり，1990 年の 更年期女性を対象にした 10 の症例対照研究をまとめた 報告 ${ }^{105)}$ では正の関連が認められている。1993 年の報 告 ${ }^{106)}$ では, 12 の症例対照研究をまとめると, 相対危険 は 1.31 (1.02-1.68) と有意となったが，6のコホート研 究をまとめると相対危険は $0.95(0.84-1.08)$ と関連は認 められなかった。1996 年の 34 万人を対象にした 7 のコ ホート研究をまとめた報告 ${ }^{107)}$ では関連は認められてい ない。2001年の 35 万人を対象にした 8 のコホート研究 をまとめた報告108) でも関連は認められていない。

以上の結果から, 症例対照研究からは乳がんと飽和脂 肪酸摂取量の弱い正の関連が認められるが，コホート研

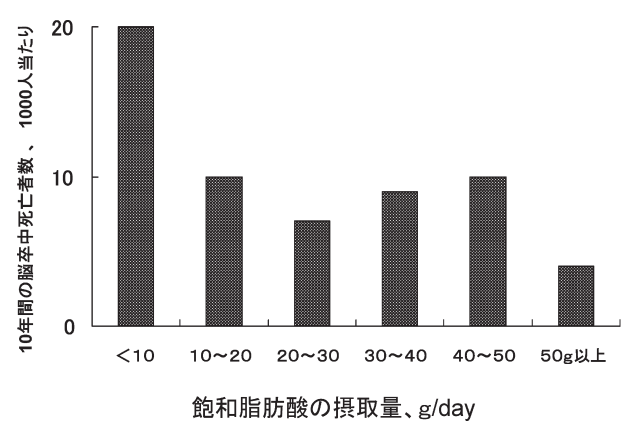

図 4 ハワイ日系中高年男性における, 飽和脂肪酸 摂取量と 10 年間の脳卒中による死亡者数 (Honolulu Heart Program ${ }^{6)}$ )

Multivariate logistic model で年齢, 収縮期血圧, BMI, 身体活動量, 夕バコの本数を補正後, $p<$ 0.05 で有意差あり。 


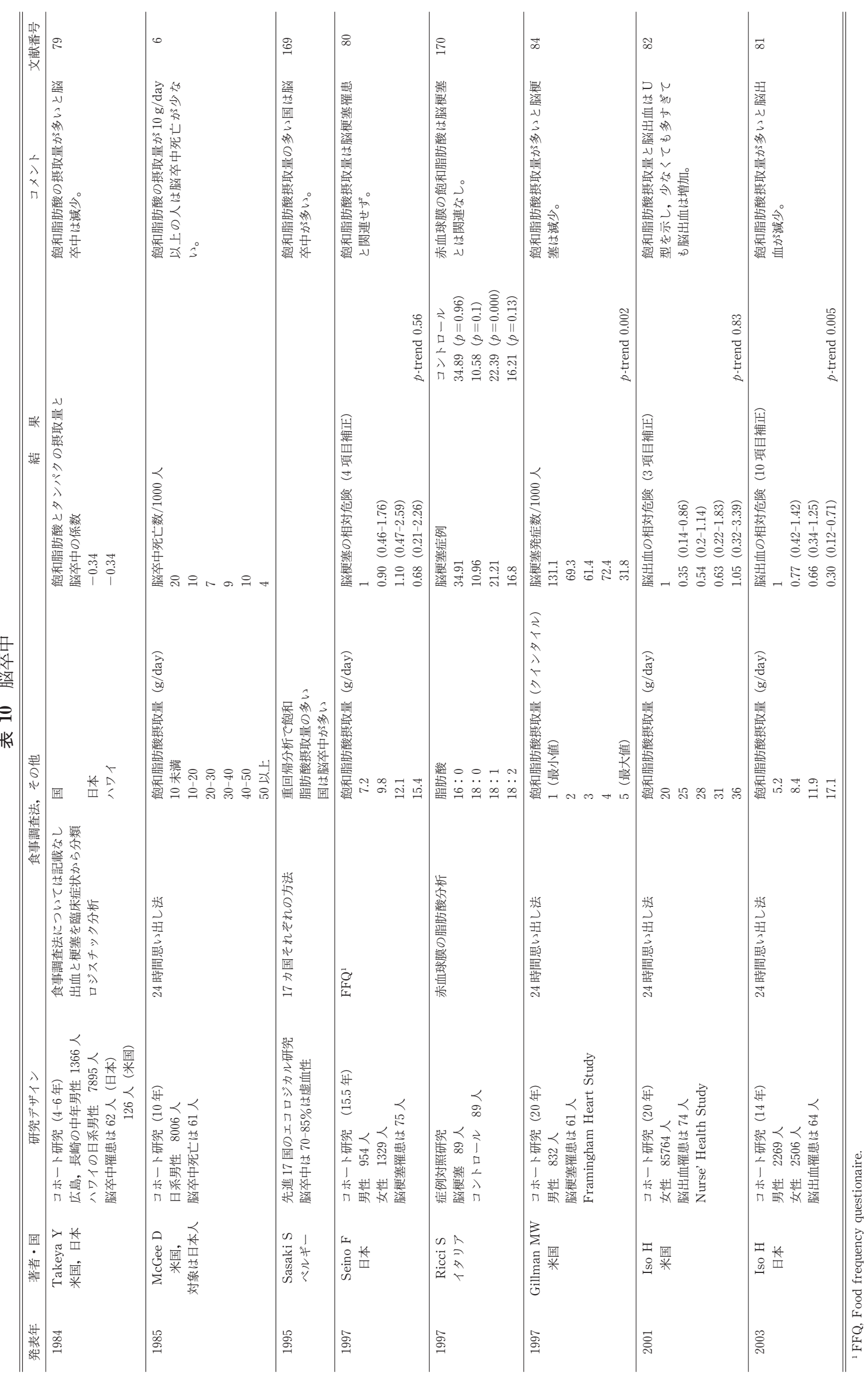




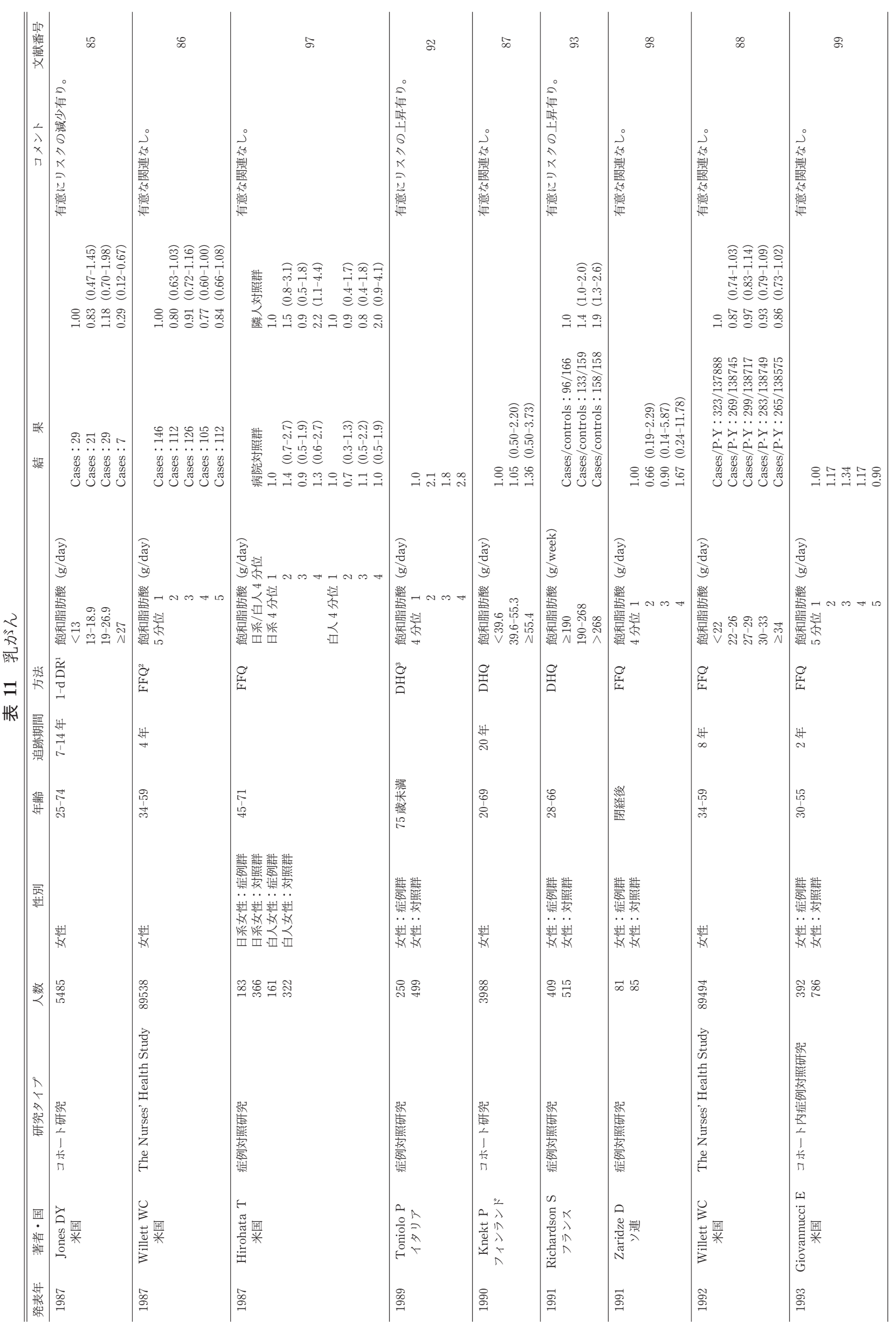




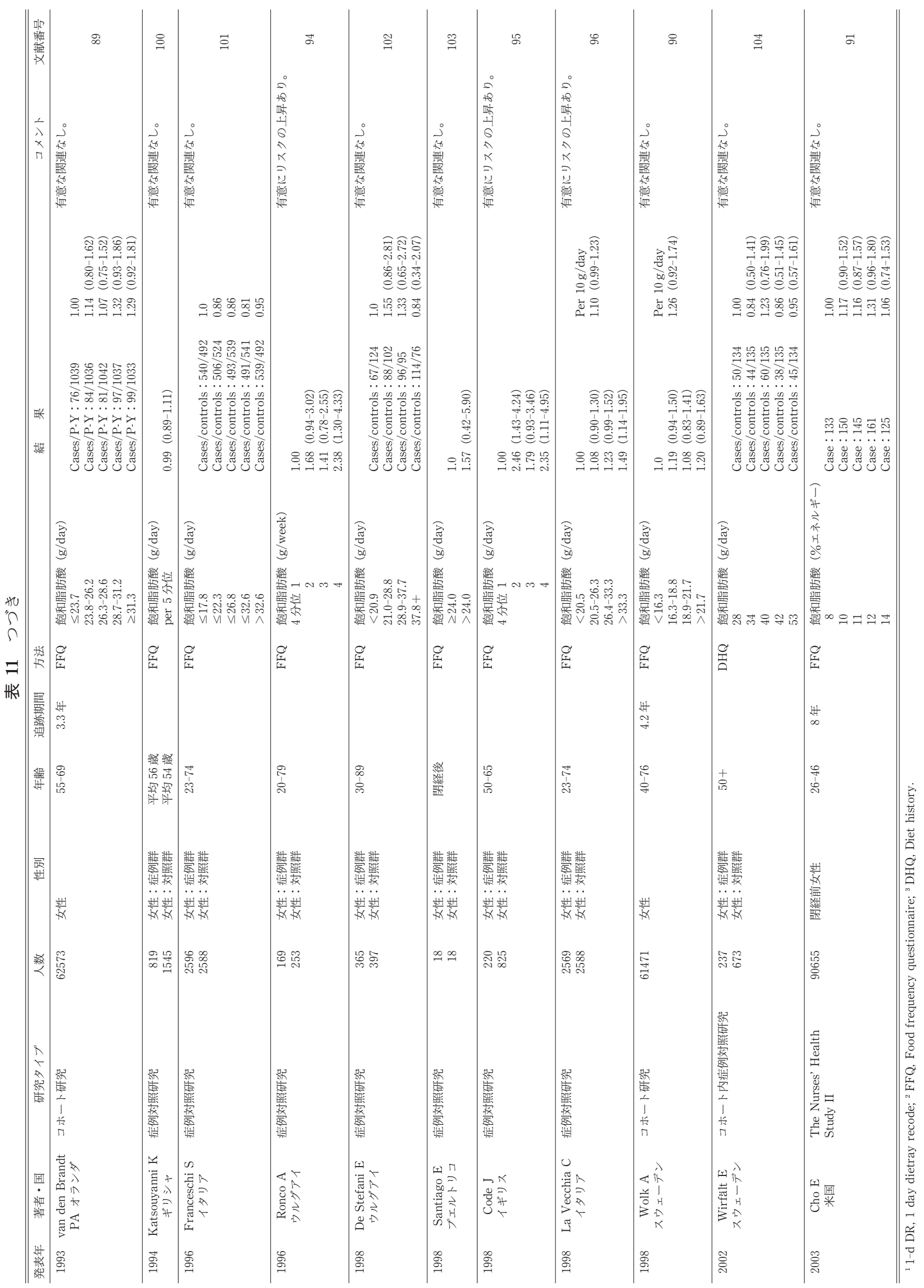




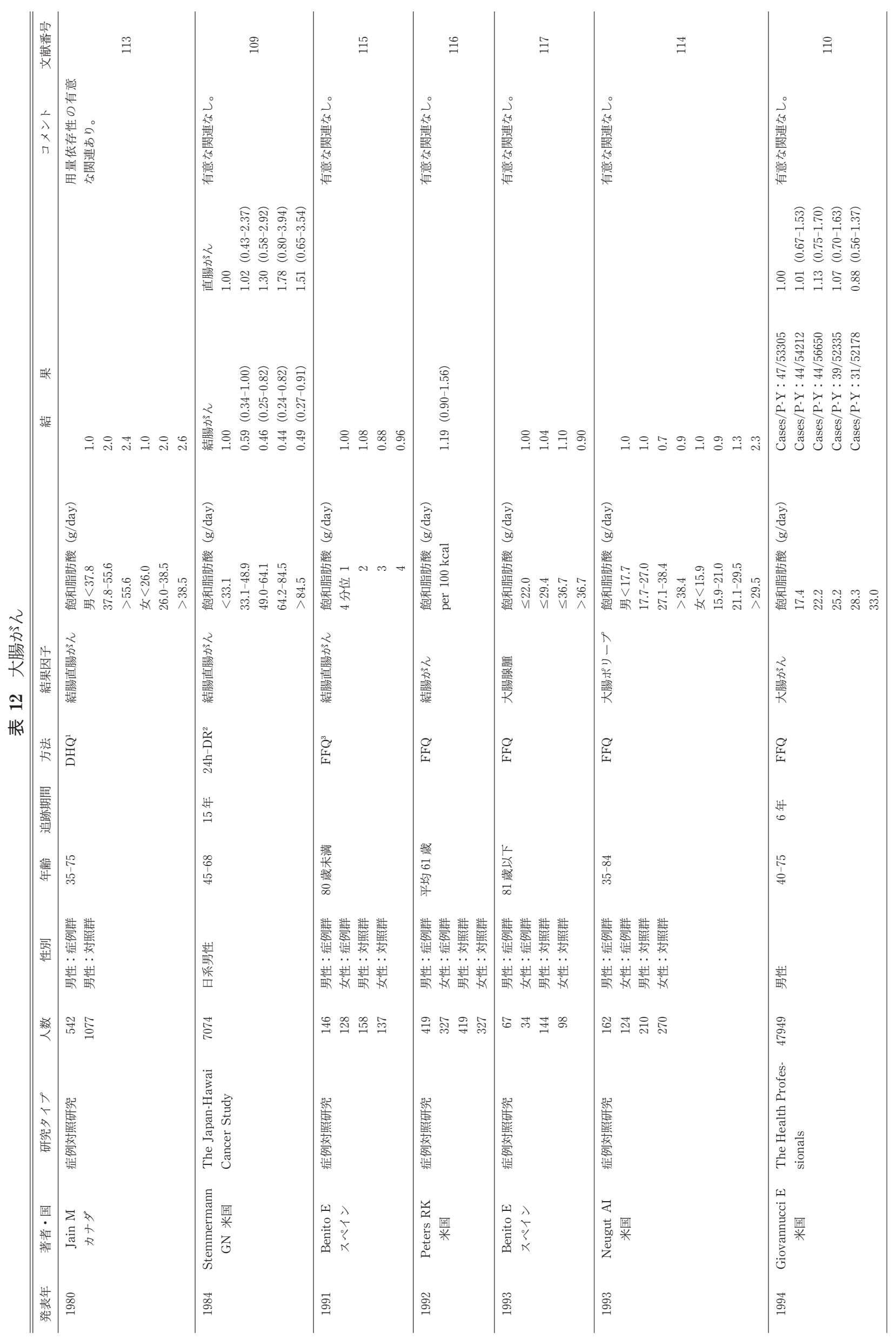




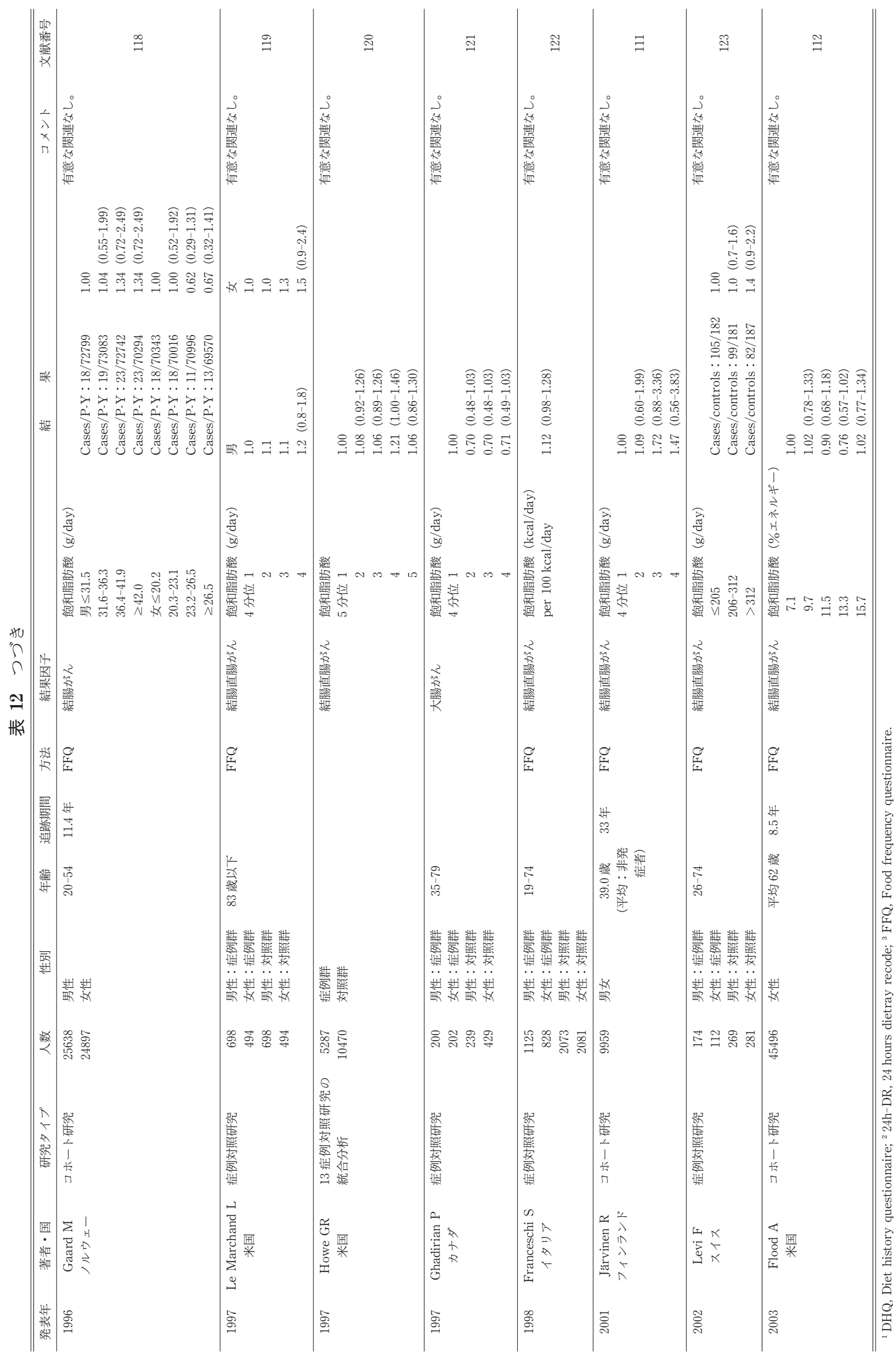


究からは関連は認められていない。結果が一致していな いため, 飽和脂肪酸摂取量と乳がん罹患との関連の有無 は不明である。

\section{7. 大腸がん（表 12）}

コホート研究109-112) が 4 報あり，関連は認められて いない。八ワイ在住の日系男性を対象にした報告 ${ }^{109)}$ で も関連はなかった。症例対照研究は 11 報あり, 正の関 連を認めた研究 ${ }^{113)}$ が 1 報告, 関連なし ${ }^{114-123)}$ が 10 報 告あった。飽和脂肪酸摂取と大腸がん罹患との関連はな いと思われる。

\section{8. 前立腺がん（表 13）}

コホート研究124-126) が 3 報あり, 関連は認められて いない。症例対照研究は 11 報あり, 正の関連 ${ }^{127-129)}$ が 3 報告, 関連なし ${ }^{130-136)}$ が 7 報告あった。関連なしの研 究の方が多いが, 症例対照研究で関連を認めた報告が 3 報告あり, 飽和脂肪酸摂取と前立腺がんの罹患には関連 があるかどうかは不明である。

9. 肺 が ん（表 14）

コホート研究137-139) が 3 報あり, 関連は認められて いない。症例対照研究は 6 報あり, 正の関連を示す研 究140-142) が 3 報告, 関連なしの研究 ${ }^{143-145)}$ が 3 報告 あった。2002 年の八つのコホート研究をまとめたメ夕 アナリシス ${ }^{146)}$ (男性 15 万人，女性 28 万人を対象）で は，喫煙を含む多くの交絡変数を考慮しても，最大飽和 脂肪酸摄取群の最低摂取群に対する相対危険は，1.01 (0.89-1.14) となり, 関連は認められていない。以上の 結果から, 症例対照研究とコホート研究の結果が一致し ていないため, 飽和脂肪酸摂取量と肺がんの罹患との関 連の有無は不明である。

\section{0. 膵藏がん（表 15）}

コホート研究 ${ }^{147) 148)}$ が 2 報あり, 関連は認められてい ない。症例対照研究は 3 報あり, 正の関連 ${ }^{149)}$ が 1 報告, 関連なし ${ }^{150) 1511}$ が 2 報告あった。飽和脂肪酸摂取と膵㵴 がん罹患とは関連ないと思われる。

11. 胃 が ん（表 16)

症例対照研究は 2 報あり, 正の関連 ${ }^{152)}$ が 1 報告, 関 連なし ${ }^{153)}$ が 1 報告あった。飽和脂肪酸摂取と胃がんと の関連は明らかでない。

12. その他のがん（表 17）

腎腺がん, 膀胱がん, 口腔・咽頭がん，非ホジキンリ ンパ腫，非セミノーマ，子宮体がんで正の関連が認めら れた報告 ${ }^{154-159)}$ が一つずつある。日本人 ${ }^{160)}$ では膀胱が んで, 負の関連が認められている。これらのがんに関し ては報告が少なく, 飽和脂肪酸摂取量との関連は明らか でない。

以上の結果から，心筋梗塞，肥満や糖尿病を予防する ため飽和脂肪酸摄取量の上限値（これ以下の摂取が好ま しい）が, 脳出血を予防するため下限值（これ以上の摂 取が好ましい) が必要であることがわかる。がんに関し

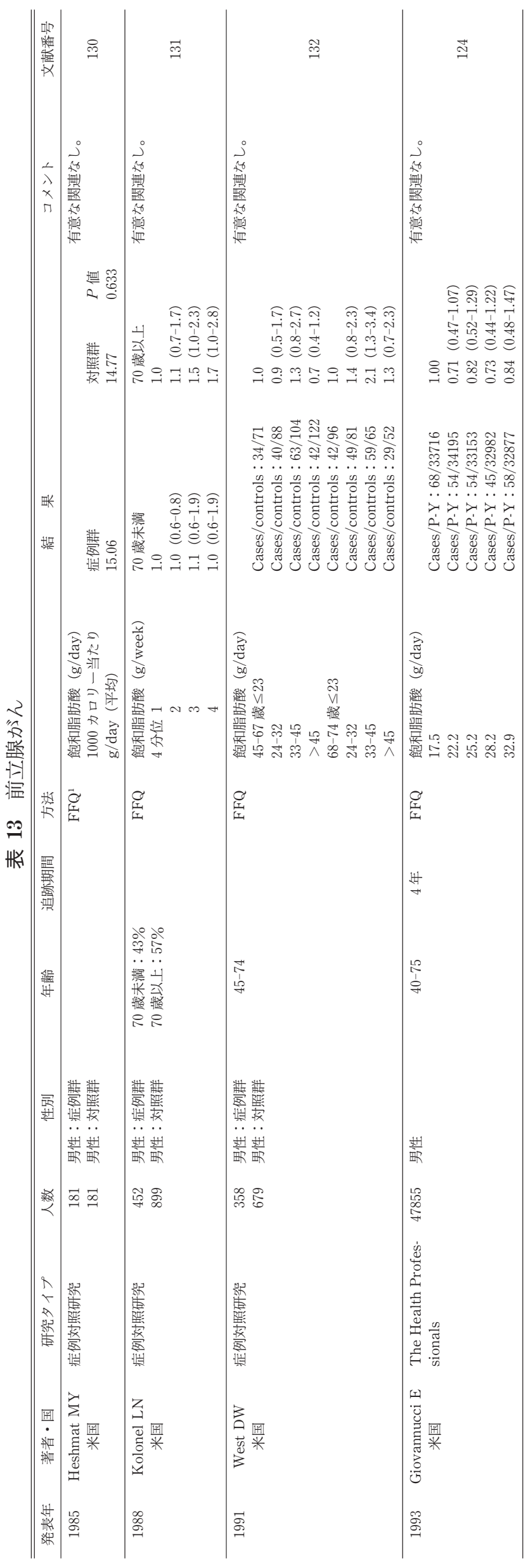




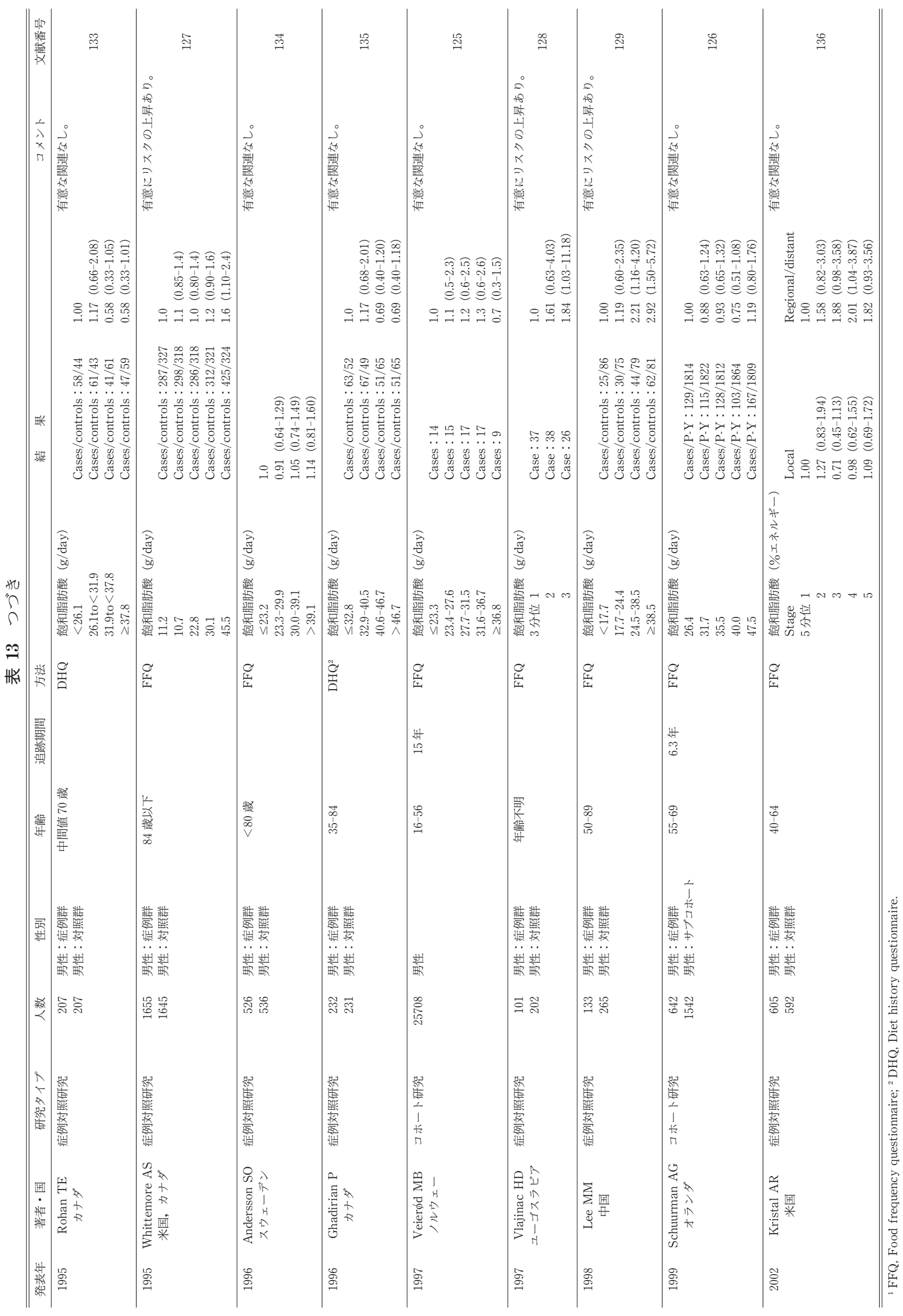




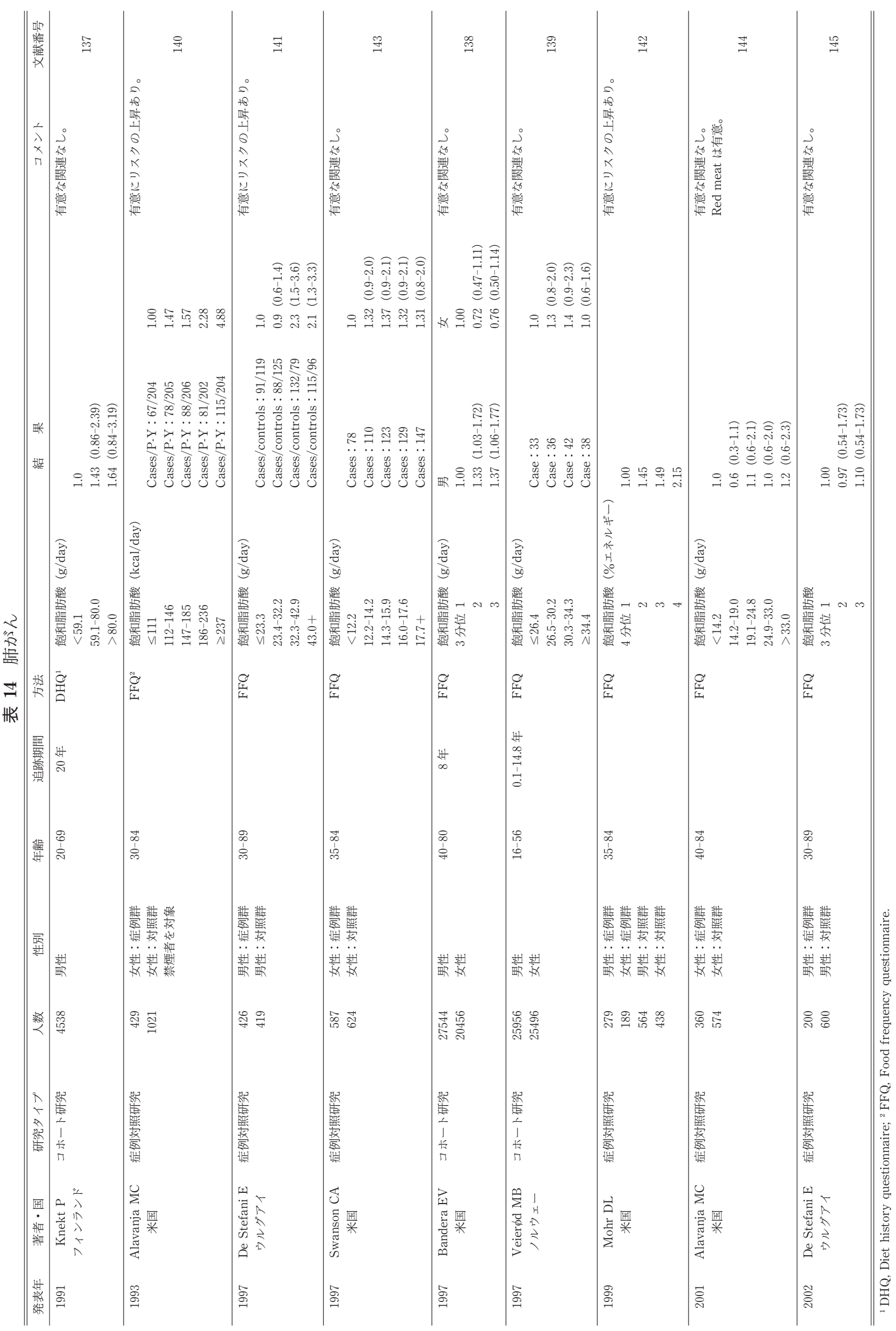




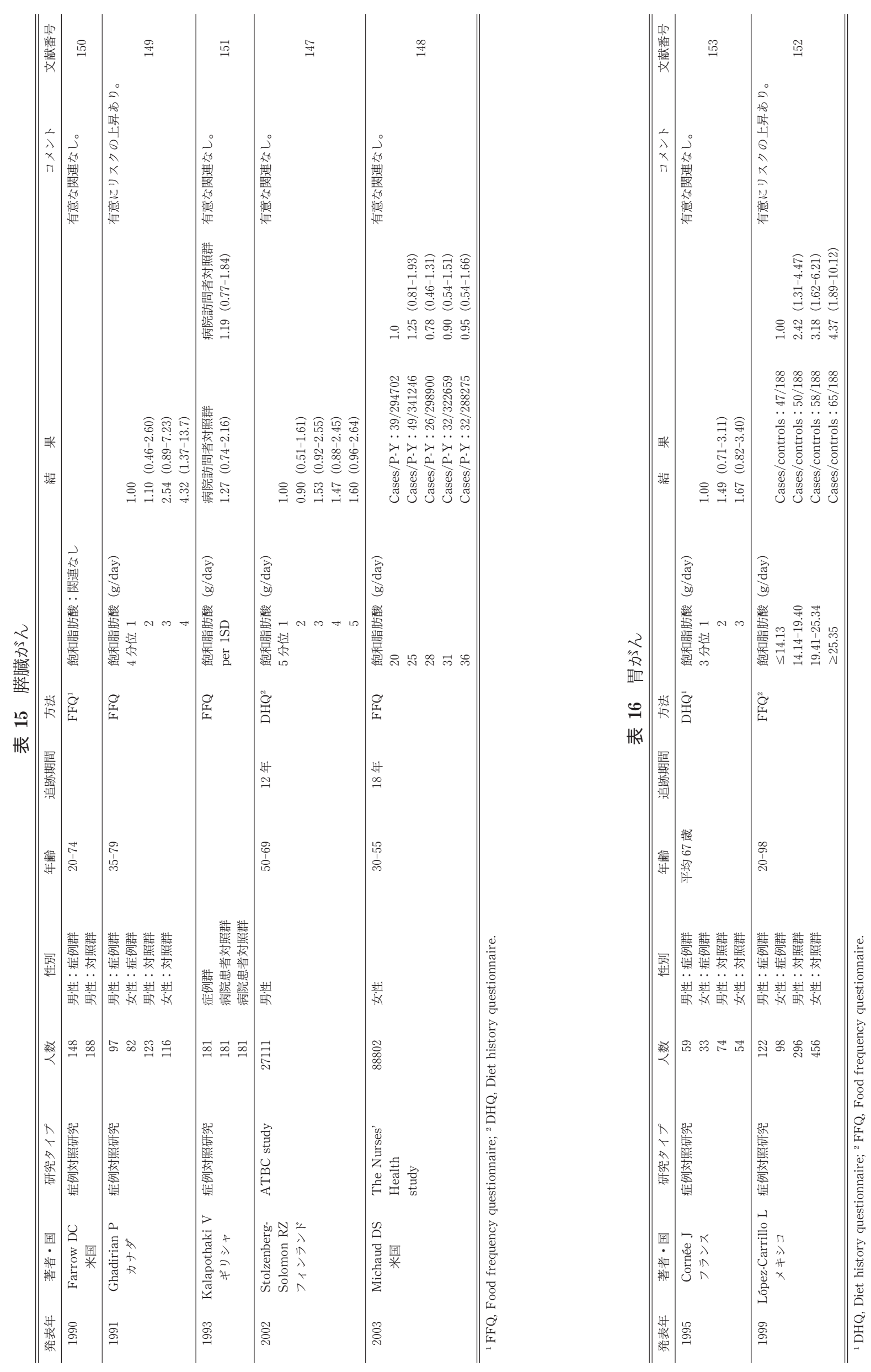




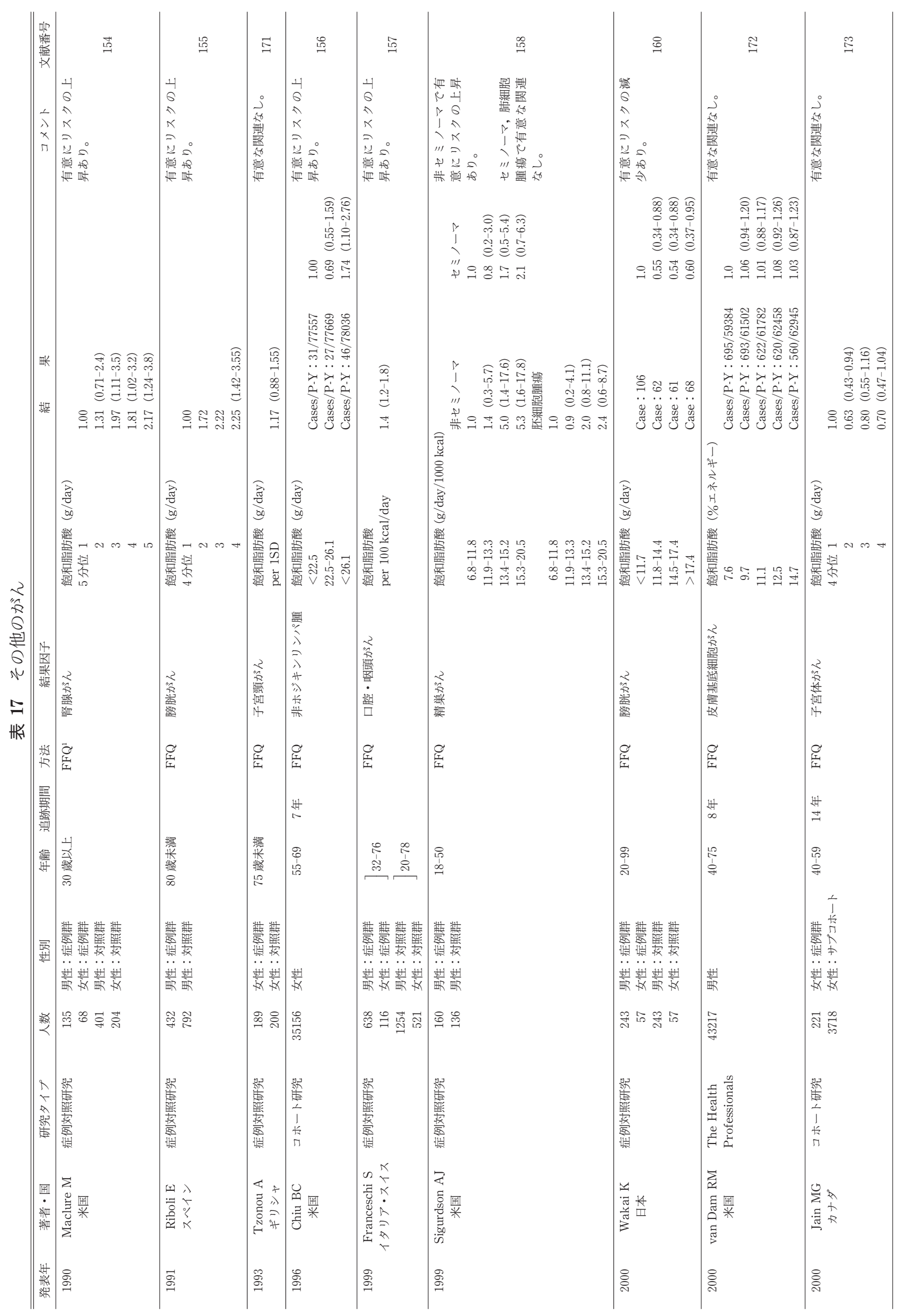




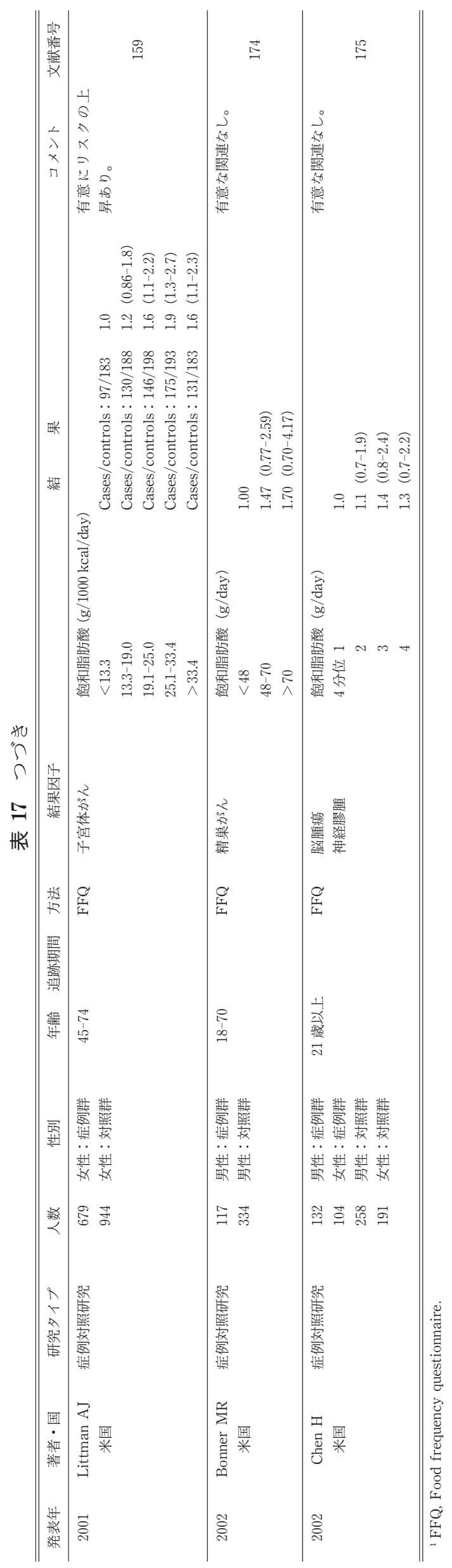

ては結果が一致せず，結論が得られていないので，がん 予防のための飽和脂肪酸摂取量を設定することは困難で ある。

\section{飽和脂肪酸の上限值は $7 \%$ エネルギー}

大規模コホート研究から，交絡変数の影響を除かない 場合, 図 1,2 亿示すようにそれぞれ, 飽和脂肪酸摂取 量と心筋梗塞, 糖尿病に関して用量依存性の関連が認め られる。すなわち，飽和脂肪酸摄取量増加が原因で心筋 梗塞, 糖尿病が増加するかどうかは明らかでないが, 飽 和脂肪酸を多く摂取する生活習慣は, 心筋梗塞, 糖尿病 の罹患を増加することを示している。介入研究からも, $10 \%$ エネルギー未満では LDL-コレステロールが $12 \%$ 減 少するのに対し，7\%エネルギー未満ではより強い $16 \%$ の減少が認められている ${ }^{38)}$ 。これらの結果は, 欧米での 摂取量の範囲では, 飽和脂肪酸の摄取量は少なければ少 ないほど心筋梗塞, 糖尿病罹患が減少することが推定さ れる。

では, 日本人は飽和脂肪酸をどの程度摂取しているの であろうか。2005 年版日本人食事摂取基準の中で，日 本人の飽和脂肪酸摂取量の分布が初めて示された（文献 1）の p. 60)。平成 13 年国民栄養調査の粗データ・ベー スを用いて，個人別に飽和脂肪酸摄取量を計算し集計す ると, 日本人の各年代・性別飽和脂肪酸摂取量分布が得 られる。脂肪酸摂取量の各年代・性別の中央值を, 同じ 粗データ・ベース食品摂取量から計算した摄取エネル ギーの各年代・性別の中央值で割り算を行うと, 脂肪酸 摂取量中央值のエネルギー比率を求めることができる。 日本人の飽和脂肪酸摂取量のエネルギー比率の中央值 （50 パーセンタイル值）は男性 18 歳以上で 4.9-7.2\%工 ネルギー, 女性 18 歳以上で 5.4-7.9\%エネルギーで総平 均約 6.3\%エネルギーとなる。米国の USDA's Continuing Survey of Food Intake by Individuals (CSFII) の 結果 ${ }^{161)}$ では, 飽和脂肪酸摂取量のエネルギー比率は男 性 19 歳以上で 11.0-12.5\%エネルギー, 女性 19 歳以上 で10.4-12.0\%エネルギーで, 総平均 11.4\%エネルギー と日本人の倍近い。

日本で普通に生活する場合，7\%エネルギーでも十分 可能と思われ，この值が上限値に設定された11。

\section{飽和脂肪酸の下限值は $4.5 \%$ エネルギー}

日本人を対象とした研究で, 飽和脂肪酸が少ないと脳 卒中, 特に脳出血罹患が増加することを示すコホート研 究がいくつかあり, 下限值の設定が必要である。日本人 の 40-69歳男女を対象にしたコホート研究 ${ }^{81)}$ から, 飽 和脂肪酸摂取量の中央値 $18.3 \mathrm{~g} /$ day の群における脳出 血罹患率を 1 とすると, $11.9 \mathrm{~g} /$ day (=5.3\%エネルギー) の群は $2.21,8.5 \mathrm{~g} /$ day の群は $2.60,5.0 \mathrm{~g} /$ day の群は 3.37 となる。ハワイ在住の 45 歳以上の男性日系人を対 象としたコホート研究(6)では, 飽和脂肪酸の摂取量が 
$10 \mathrm{~g} /$ day（3.9\%エネルギー）以下だと, 総死亡率，が 几死亡率, 冠動脈性心疾患死亡率, 脳卒中死亡率が急増 し，10 g/day 以上の約 2 倍になることを認めている。こ のため，飽和脂肪酸摂取量が $4.6 \%$ エネルギー [ = $(5.3+$ 3.9)/2]より少ないと総死亡, 生活習慣病のリスクが高 くなる可能性があると考え，これを丸め， $4.5 \%$ エネル ギーを目標量 (下限) とし，18 歳以上の男女に適用し た1)。

\section{終わりに}

2006 年, AHA (American Heart Association) は 飽和脂肪酸の上限值を, 以前の $10 \%$ エネルギー未満か ら，7\%エネルギー未満に変更を行った ${ }^{162)}$ 。しかし，こ の最新の AHA 摂取基準でも, 飽和脂肪酸の下限值は設 定はされていない。下限值 $4.5 \%$ エネルギーは, 日本人 を対象とした研究に基づく日本人独自の摂取基準であ る。

この食事摂取基準が上手く活用され, 疾病の予防に役 立つことを期待する。

この総説は独立行政法人国立健康・栄養研究所運営交 付金, 栄養所要量策定のための系統的レビュー（主任研 究者, 佐々木敏) の一環としてまとめられた。また, 工 ビデンステーブル作成のための Key word 選定に協力し ていただいた佐藤眞一部長（大阪府立健康科学セン ター）に謝意を表する。

\section{文献}

1）第一出版編集部編（2005）厚生労働省策定日本人の 食事摂取基準。第一出版，東京.

2）健康 - 栄養情報研究会編（1999）第6 次改定日本人 の栄養所要量一食事摂取策定基準一. 第一出版, 東 京.

3) Keys A, Anderson JT, Grande F (1965) Serum cholesterol response to changes in the diet. IV Particular saturated fatty acids in the diet. Metabolism $14: 776-87$.

4) Mensink PR, Temme EH, Hornstra G (1994) Dietary saturated and trans fatty acids and lipoprotein metabolism. Ann Med 26 : 461-64.

5) Dietschy JM (1998) Dietary fatty acids and the regulation of plasma low density lipoprotein cholesterol concentrations. J Nutr 128:444S-8S.

6) McGee D, Reed D, Stemmerman G, Rhoads G, Yano K, Feinleib M (1985) The relationship of dietary fat and cholesterol to mortality in 10 years: the Honolulu Heart Program. Int $J$ Epidemiol 14 : 97-105.

7) Appleby PN, Thorogood M, Mann JI, Key TJ (1999) The Oxford Vegetarian Study: an overview. Am J Clin Nutr 70:525S-31S.

8) Kesteloot H, Lesaffre E, Joossens JV (1991) Dairy fat, saturated animal fat, and cancer risk.
Prev Med $20: 226-36$.

9) Staessen L, De Bacquer D, De Henauw S, De Backer G, Van Peteghem C (1997) Relation between fat intake and mortality: an ecological analysis in Belgium. Eur $J$ Cancer Prev 6 : 37481.

10) Kromhout D, Bloemberg B, Feskens E, Menotti A, Nissinen A (2000) Saturated fat, vitamin C and smoking predict long-term population all-cause mortality rates in the Seven Countries Study. Int J Epidemiol 29:260-5.

11) Mensink PR, Katan MB (1992) Effect of dietary fatty acids on serum lipids and lipoproteins. A meta-analysis of 27 trials. Arterioscler Thromb 12: 911-19.

12) Hegsted DM, Ausman LM, Johnson JA, Dallal GE (1993) Dietary fat and serum lipids: an evaluation of the experimental data. Am J Clin Nutr 57 : 875-83.

13) Clarke R, Frost C, Collins R, Appleby P, Peto R (1997) Dietary lipids and blood cholesterol: quantitative meta-analysis of metabolic ward studies. BMJ $314: 112-17$.

14) Hobbs HH, Brown MS, Goldstein JL (1992) Molecular genetics of the LDL receptor gene in familial hypercholesterolemia. Hum Mutat 1: 445-66.

15）江崎 治，窄野昌信，三宅吉博，三戸夏子（2005） コレステロール摂取基準の考え方。日本栄養・食糧 学会誌 58, 69-83.

16) Kushi LH, Lew RA, Stare FJ, Ellison CR, el Lozy M, Bourke G, Daly L, Graham I, Hickey N, Mulcahy R, Kevaney J (1985) Diet and 20-year mortality from coronary heart disease. The Ireland-Boston Diet-Heart Study. $N$ Engl J Med 312:811-8.

17) Posner BM, Cobb JL, Belanger AJ, Cupples LA, D’Agostino RB, Stokes J 3rd (1991) Dietary lipid predictors of coronary heart disease in men. The Framingham Study. Arch Intern Med 151: 1181-7.

18) Esrey KL, Joseph L, Grover SA (1996) Relationship between dietary intake and coronary heart disease mortality: lipid research clinics prevalence follow-up study. J Clin Epidemiol 49: 211-6.

19) Ascherio A, Rimm EB, Giovannucci EL, Spiegelman D, Stampfer M, Willett WC (1996) Dietary fat and risk of coronary heart disease in men: cohort follow up study in the United States. BMJ 313:84-90.

20) Pietinen $P$, Ascherio A, Korhonen $P$, Hartman AM, Willett WC, Albanes D, Virtamo J (1997) Intake of fatty acids and risk of coronary heart disease in a cohort of Finnishmen. The AlphaTocopherol, Beta-Carotene Cancer Prevention Study. Am J Epidemiol 145:876-87.

21) $\mathrm{Hu} \mathrm{FB}$, Stampfer MJ, Manson JE, Rimm E, 
Colditz GA, Rosner BA, Hennekens CH, Willett WC (1997) Dietary fat intake and the risk of coronary heart disease in women. $N$ Engl J Med $337: 1491-9$.

22) Mann JI, Appleby PN, Key TJ, Thorogood M (1997) Dietary determinants of ischaemic heart disease in health conscious individuals. Heart 78 : 450-5.

23) Hu FB, Stampfer MJ, Rimm E, Ascherio A, Rosner BA, Spiegelman D, Willett WC (1999) Dietary fat and coronary heart disease: a comparison of approaches for adjusting for total energy intake and modeling repeated dietary measurements. Am J Epidemiol 149 : 531-40.

24) Hu FB, Stampfer MJ, Manson JE, Ascherio A, Colditz GA, Speizer FE, Hennekens CH, Willett WC (1999) Dietary saturated fats and their food sources in relation to the risk of coronary heart disease in women. Am J Clin Nutr 70 : 1001-8.

25) Boniface DR, Tefft ME (2002) Dietary fats and 16-year coronary heart disease mortality in a cohort of men and women in Great Britain. Eur $J$ Clin Nutr $56:$ 786-92.

26) Oh K, Hu FB, Manson JE, Stampfer MJ, Willett WC (2005) Dietary fat intake and risk of coronary heart disease in women: 20 years of followup of the nurses' health study. Am J Epidemiol 161:672-9.

27) Stampfer MJ, Hu FB, Manson JE, Rimm EB, Willett WC (2000) Primary prevention of coronary heart disease in women through diet and lifestyle. $N$ Engl J Med 343:16-22.

28) Tzonou A, Kalandidi A, Trichopoulou A, Hsieh CC, Toupadaki N, Willett W, Trichopoulos D (1993) Diet and coronary heart disease: a casecontrol study in Athens, Greece. Epidemiology 4 : 511-6.

29) Suh I, Oh KW, Lee KH, Psaty BM, Nam CM, Kim SI, Kang HG, Cho SY, Shim WH (2001) Moderate dietary fat consumption as a risk factor for ischemic heart disease in a population with a low fat intake: a case-control study in Korean men. Am J Clin Nutr 73:722-7.

30) Singh RB, Niaz MA, Ghosh S, Beegom R, Agarwal P, Nangia S, Moshiri M, Janus ED (1998) Low fat intake and coronary artery disease in a population with higher prevalence of coronary artery disease: the Indian paradox. $J \mathrm{Am}$ Coll Nutr $17: 342-50$.

31) Keys A, Buchem CA, Blackburn H, Buzina R, Donta AS, Fidanza F, Karvonen MJ, Menotti A, Nedeljkovic S, Puddu V, Taylor HL (1981) The diet and all-causes death rate in the Seven Countries Study. Lancet 2:58-61.

32) Kromhout D, Menotti A, Bloemberg B, Aravanis C, Blackburn H, Buzina R, Dontas AS, Fidanza F, Giampaoli S, Jansen A, Karvonen M, Katan M, Nissinen A, Nedeljkovic S, Pekkanen J, Pekkar- inen M, Punsar S, Rasanen L, Simic B, Toshima H (1995) Dietary saturated and trans fatty acids and cholesterol and 25-year mortality from coronary heart disease: the Seven Countries Study. Prev Med $24: 308-15$.

33) Nakamura T, Azuma A, Kuribayashi T, Sugihara H, Okuda S, Nakagawa M (2003) Serum fatty acid levels, dietary style and coronary heart disease in three neighbouring areas in Japan: the Kumihama study. Br J Nutr 89:267-72.

34) Dwyer T, Emmanuel SC, Janus ED, Wu Z, Hynes KL, Zhang C (2003) The emergence of coronary heart disease in populations of Chinese descent. Atherosclerosis $167: 303-10$.

35) Turpeinen O, Karvonen MJ, Pekkarinen M, Miettinen M, Elosuo R, Paavilainen E (1979) Dietary prevention of coronary heart disease: the Finnish Mental Hospital Study. Int J Epidemiol $8: 99-118$.

36) Blankenhorn DH, Johnson RL, Mack WJ, el Zein HA, Vailas LI (1990) The influence of diet on the appearance of new lesions in human coronary arteries. JAMA $263: 1646-52$.

37) Watts GF, Jackson P, Mandalia S, Brunt JN, Lewis ES, Coltart DJ, Lewis B (1994) Nutrient intake and progression of coronary artery disease. Am J Cardiol $73: 328-32$.

38) Yu-Poth S, Zhao G, Etherton T, Naglak M, Jonnalagadda S, Kris-Etherton PM (1999) Effects of the National Cholesterol Education Program's Step I and Step II dietary intervention programs on cardiovascular disease risk factors: a metaanalysis. Am J Clin Nutr 69:632-46.

39) Maron DJ, Fair JM, Haskell WL (1991) Saturated fat intake and insulin resistance in men with coronary artery disease. The Stanford Coronary Risk Intervention Project Investigators and Staff. Circulation $84: 2020-7$.

40) Mayer EJ, Newman B, Quesenberry CP Jr, Selby JV (1993) Usual dietary fat intake and insulin concentrations in healthy women twins. Diabetes Care $16: 1459-69$.

41) Ward KD, Sparrow D, Vokonas PS, Willett WC, Landsberg L, Weiss ST (1994) The relationships of abdominal obesity, hyperinsulinemia and saturated fat intake to serum lipid levels: the Normative Aging Study. Int $J$ Obes Relat Metab Disord $18: 137-44$.

42) Obarzanek E, Schreiber GB, Crawford PB, Goldman SR, Barrier PM, Frederick MM, Lakatos E (1994) Energy intake and physical activity in relation to indexes of body fat: the National Heart, Lung, and Blood Institute Growth and Health Study. Am J Clin Nutr 60:15-22.

43) Larson DE, Hunter GR, Williams MJ, KekesSzabo T, Nyikos I, Goran MI (1996) Dietary fat in relation to body fat and intraabdominal adipose tissue: a cross-sectional analysis. Am J Clin 
Nutr 64:677-84.

44) Singh RB, Niaz MA, Ghosh S, Beegom R, Agarwal P, Nangia S, Moshiri M, Janus ED (1998) Low fat intake and coronary artery disease in a population with higher prevalence of coronary artery disease: the Indian paradox. $J \mathrm{Am}$ Coll Nutr $17: 342-50$.

45) Alfieri M, Pomerleau J, Grace DM (1997) A comparison of fat intake of normal weight, moderately obese and severely obese subjects. Obes Surg $7: 9-15$.

46) Gonzalez CA, Pera G, Quiros JR, Lasheras C, Tormo MJ, Rodriguez M, Navarro C, Martinez C, Dorronsoro M, Chirlaque MD, Beguiristain JM, Barricarte A, Amiano P, Agudo A (2000) Types of fat intake and body mass index in a Mediterranean country. Public Health Nutr 3:329-36.

47) Brunner EJ, Wunsch H, Marmot MG (2001) What is an optimal diet? Relationship of macronutrient intake to obesity, glucose tolerance, lipoprotein cholesterol levels and the metabolic syndrome in the Whitehall II study. Int J Obes Relat Metab Disord $25: 45-53$.

48) Luan J, Browne PO, Harding AH, Halsall DJ, O'Rahilly S, Chatterjee VK, Wareham NJ (2001) Evidence for gene-nutrient interaction at the PPARgamma locus. Diabetes $50: 686-9$.

49) Mayer-Davis EJ, Levin S, Bergman RN, D'Agostino RB Jr, Karter AJ, Saad MF, Insulin Resistance Atherosclerosis Study (IRAS) (2001) Insulin secretion, obesity, and potential behavioral influences: results from the Insulin Resistance Atherosclerosis Study (IRAS). Diabetes Metab Res Rev $17:$ 137-45.

50) Garaulet M, Perez-Llamas F, Canteras M, Tebar FJ, Zamora S (2001) Endocrine, metabolic and nutritional factors in obesity and their relative significance as studied by factor analysis. Int $J$ Obes Relat Metab Disord 25 : 243-51.

51) Ramos de Marins VM, Varnier Almeida RM, Pereira RA, Barros MB (2001) Factors associated with overweight and central body fat in the city of Rio de Janeiro: results of a two-stage random sampling survey. Public Health 115：23642.

52) Trichopoulou A, Gnardellis C, Benetou V, Lagiou P, Bamia C, Trichopoulos D (2002) Lipid, protein and carbohydrate intake in relation to body mass index. Eur J Clin Nutr 56:37-43.

53 ) Agurs-Collins TD, Kumanyika SK, Ten Have TR, Adams-Campbell LL (1997) A randomized controlled trial of weight reduction and exercise for diabetes management in older AfricanAmerican subjects. Diabetes Care 20 : 1503-11.

54) Eriksson J, Lindstrom J, Valle T, Aunola S, Hamalainen H, Ilanne-Parikka P, KeinanenKiukaanniemi S, Laakso M, Lauhkonen M, Lehto $\mathrm{P}$, Lehtonen A, Louheranta A, Mannelin M,
Martikkala V, Rastas M, Sundvall J, Turpeinen A, Viljanen T, Uusitupa M, Tuomilehto J (1999) Prevention of Type II diabetes in subjects with impaired glucose tolerance: the Diabetes Prevention Study (DPS) in Finland. Study design and 1-year interim report on the feasibility of the lifestyle intervention programme. Diabetologia 42:793-801.

55) Tuomilehto J, Lindstrom J, Eriksson JG, Valle TT, Hamalainen H, Ilanne-Parikka P, KeinanenKiukaanniemi S, Laakso M, Louheranta A, Rastas M, Salminen V, Uusitupa M, Finnish Diabetes Prevention Study Group (2001) Prevention of type 2 diabetes mellitus by changes in lifestyle among subjects with impaired glucose tolerance. $N$ Engl J Med $344: 1343-50$.

56) Kriketos AD, Robertson RM, Sharp TA, Drougas H, Reed GW, Storlien LH, Hill JO (2001) Role of weight loss and polyunsaturated fatty acids in improving metabolic fitness in moderately obese, moderately hypertensive subjects. $J$ Hypertens 19: 1745-54.

57) Summers LK, Fielding BA, Bradshaw HA, Ilic V, Beysen C, Clark ML, Moore NR, Frayn KN (2002) Substituting dietary saturated fat with polyunsaturated fat changes abdominal fat distribution and improves insulin sensitivity. Diabetologia $45: 369-77$.

58) Lindstrom J, Eriksson JG, Valle TT, Aunola S, Cepaitis Z, Hakumaki M, Hamalainen H, IlanneParikka P, Keinanen-Kiukaanniemi S, Laakso M, Louheranta A, Mannelin M, Martikkala V, Moltchanov V, Rastas M, Salminen V, Sundvall J, Uusitupa M, Tuomilehto J (2003) Prevention of diabetes mellitus in subjects with impaired glucose tolerance in the finnish diabetes prevention study: results from a randomized clinical trial. $J$ Am Soc Nephrol 14: S108-13.

59) Matsuo T, Takeuchi H, Suzuki H, Suzuki M (2002) Body fat accumulation is greater in rats fed a beef tallow diet than in rats fed a safflower or soybean oil diet. Asia Pac J Clin Nutr 11:3028.

60) Matsuo T, Shimomura Y, Saitoh S, Tokuyama K, Takeuchi H, Suzuki M (1995) Sympathetic activity is lower in rats fed a beef tallow diet than in rats fed a safflower oil diet. Metabolism 44 : 934-9.

61) Ikemoto S, Takahashi M, Tsunoda N, Maruyama K, Itakura H, Ezaki O (1996) High-fat dietinduced hyperglycemia and obesity in mice: differential effects of dietary oils. Metabolism 45:153946.

62) Hu FB, Manson JE, Stampfer MJ, Colditz G, Liu S, Solomon CG, Willett WC (2001) Diet, lifestyle, and the risk of type 2 diabetes mellitus in women. $N$ Engl J Med 345: 790-7.

63) Feskens EJ, Virtanen SM, Rasanen L, Tuomilehto J, Stengard J, Pekkanen J, Nissinen A, Krom- 
hout D (1995) Dietary factors determining diabetes and impaired glucose tolerance. A 20year follow-up of the Finnish and Dutch cohorts of the Seven Countries Study. Diabetes Care 18: 1104-12.

64) Meyer KA, Kushi LH, Jacobs DR Jr, Folsom AR (2001) Dietary fat and incidence of type 2 diabetes in older Iowa women. Diabetes Care 24 : 1528-35.

65) Salmeron J, Hu FB, Manson JE, Stampfer MJ, Colditz GA, Rimm EB, Willett WC (2001) Dietary fat intake and risk of type 2 diabetes in women. Am J Clin Nutr $73:$ 1019-26.

66) van Dam RM, Willett WC, Rimm EB, Stampfer MJ, Hu FB (2002) Dietary fat and meat intake in relation to risk of type 2 diabetes in men. Diabetes Care 25: 417-24.

67) Wang L, Folsom AR, Zheng ZJ, Pankow JS, Eckfeldt JH, ARIC Study Investigators (2003) Plasma fatty acid composition and incidence of diabetes in middle-aged adults: the Atherosclerosis Risk in Communities (ARIC) Study. Am J Clin Nutr 78:91-8.

68) Fujimoto WY, Bergstrom RW, Boyko EJ, Kinyoun JL, Leonetti DL, Newell-Morris LL, Robinson LR, Shuman WP, Stolov WC, Tsunehara CH, Wahl PW (1994) Diabetes and diabetes risk factors in second- and third-generation Japanese Americans in Seattle, Washington. Diabetes Res Clin Pract 24 Suppl : S43-52.

69) Tuomilehto J, Lindstrom J, Eriksson JG, Valle TT, Hamalainen H, Ilanne-Parikka P, KeinanenKiukaanniemi S, Laakso M, Louheranta A, Rastas M, Salminen V, Uusitupa M, Finnish Diabetes Prevention Study Group (2001) Prevention of type 2 diabetes mellitus by changes in lifestyle among subjects with impaired glucose tolerance. $N$ Engl J Med 344:1343-50.

70) Lindström J, Eriksson JG, Valle TT, Aunola S, Cepaitis Z, Hakumaki M, Hamalainen H, IlanneParikka P, Keinanen-Kiukaanniemi S, Laakso M, Louheranta A, Mannelin M, Martikkala V, Moltchanov V, Rastas M, Salminen V, Sundvall J, Uusitupa M, Tuomilehto J (2003) Prevention of diabetes mellitus in subjects with impaired glucose tolerance in the finnish diabetes prevention study: results from a randomized clinical trial. $J$ Am Soc Nephrol 14: S108-13.

71) Maron DJ, Fair JM, Haskell WL (1991) Saturated fat intake and insulin resistance in men with coronary artery disease. The Stanford Coronary Risk Intervention Project Investigators and Staff. Circulation 84 : 2020-7.

72) Mayer EJ, Newman B, Quesenberry CP Jr, Selby JV (1993) Usual dietary fat intake and insulin concentrations in healthy women twins. Diabetes Care 16 : 1459-69.

73) Feskens EJ, Loeber JG, Kromhout D (1994) Diet and physical activity as determinants of hyperinsulinemia: the Zutphen Elderly Study. Am J Epidemiol 140 : 350-60.

74) Marshall JA, Bessesen DH, Hamman RF (1997) High saturated fat and low starch and fibre are associated with hyperinsulinaemia in a nondiabetic population: the San Luis Valley Diabetes Study. Diabetologia 40:430-8.

75) Vessby B, Unsitupa M, Hermansen K, Riccardi G, Rivellese AA, Tapsell LC, Nalsen C, Berglund L, Louheranta A, Rasmussen BM, Calvert GD, Maffetone A, Pedersen E, Gustafsson IB, Storlien LH, KANWU Study (2001) Substituting dietary saturated for monounsaturated fat impairs insulin sensitivity in healthy men and women: The KANWU Study. Diabetologia $44: 312-9$.

76) Perez-Jimenez F, Lopez-Miranda J, Pinillos MD, Gomez P, Paz-Rojas E, Montilla P, Marin C, Velasco MJ, Blanco-Molina A, Jimenez Pereperez JA, Ordovas JM (2001) A Mediterranean and a high-carbohydrate diet improve glucose metabolism in healthy young persons. Diabetologia 44 : 2038-43.

77) Fasching P, Ratheiser K, Schneeweiss B, Rohac M, Nowotny P, Waldhausl W (1996) No effect of short-term dietary supplementation of saturated and poly- and monounsaturated fatty acids on insulin secretion and sensitivity in healthy men. Ann Nutr Metab $40: 116-22$.

78) Lovejoy JC, Smith SR, Champagne CM, Most MM, Lefevre M, DeLany JP, Denkins YM, Rood JC, Veldhuis J, Bray GA (2002) Effects of diets enriched in saturated (palmitic), monounsaturated (oleic), or trans (elaidic) fatty acids on insulin sensitivity and substrate oxidation in healthy adults. Diabetes Care 25:1283-8.

79) Takeya Y, Popper JS, Shimizu Y, Kato H, Rhoads GG, Kagan A (1984) Epidemiologic studies of coronary heart disease and stroke in Japanese men living in Japan, Hawaii and California: incidence of stroke in Japan and Hawaii. Stroke $15: 15-23$.

80) Seino F, Date C, Nakayama T, Yoshiike N, Yokoyama T, Yamaguchi M, Tanaka H (1997) Dietary lipids and incidence of cerebral infarction in a Japanese rural community. J Nutr Sci Vitaminol $43:$ 83-99.

81) Iso H, Sato S, Kitamura A, Naito Y, Shimamoto T, Komachi Y (2003) Fat and protein intakes and risk of intraparenchymal hemorrhage among middle-aged Japanese. Am J Epidemiol 157: 32-9.

82) Iso H, Stampfer MJ, Manson JE, Rexrode K, Hu F, Hennekens CH, Colditz GA, Speizer FE, Willett WC (2001) Prospective study of fat and protein intake and risk of intraparenchymal hemorrhage in women. Circulation 103 : 856-63.

83) He K, Merchant A, Rimm EB, Rosner BA, Stamp- 
fer MJ, Willett WC, Ascherio A (2003) Dietary fat intake and risk of stroke in male US healthcare professionals: 14 year prospective cohort study. BMJ $327: 777-82$.

84) Gillman MW, Cupples LA, Millen BE, Ellison RC, Wolf PA (1997) Inverse association of dietary fat with development of ischemic stroke in men. JAMA $278: 2145-50$.

85) Jones DY, Schatzkin A, Green SB, Block G, Brinton LA, Ziegler RG, Hoover R, Taylor PR (1987) Dietary fat and breast cancer in the National Health and Nutrition Examination Survey I Epidemiologic Follow-up Study. I Natl Cancer Inst 79:465-71.

86) Willett WC, Stampfer MJ, Colditz GA, Rosner BA, Hennekens CH, Speizer FE (1987) Dietary fat and the risk of breast cancer. $N$ Engl $J$ Med $316: 22-8$.

87) Knekt P, Albanes D, Seppänen R, Aromaa A, Järvinen R, Hyvönen L, Teppo L, Pukkala E (1990) Dietary fat and risk of breast cancer. Am J Clin Nutr 52:903-8.

88) Willett WC, Hunter DJ, Stampfer MJ, Colditz G, Manson JE, Spiegelman D, Rosner B, Hennekens CH, Speizer FE (1992) Dietary fat and fiber in relation to risk of breast cancer. An 8-year follow-up. JAMA 268: 2037-44.

89) van den Brandt PA, van't Veer P, Goldbohm RA, Dorant E, Volovics A, Hermus RJ, Sturmans F (1993) A prospective cohort study on dietary fat and the risk of postmenopausal breast cancer. Cancer Res 53:75-82.

90) Wolk A, Bergström R, Hunter D, Willett W, Ljung H, Holmberg L, Bergkvist L, Bruce $\AA$, Adami HO (1998) A prospective study of association of monounsaturated fat and other types of fat with risk of breast cancer. Arch Intern Med 158: 41-5.

91) Cho E, Spiegelman D, Hunter DJ, Chen WY, Stampfer MJ, Colditz GA, Willett WC (2003) Premenopausal fat intake and risk of breast cancer. J Natl Cancer Inst 95 : 1079-85.

92) Toniolo P, Riboli E, Protta F, Charrel M, Cappa AP (1989) Calorie-providing nutrients and risk of breast cancer. J Natl Cancer Inst 81:278-86.

93) Richardson S, Gerber M, Cenée S (1991) The role of fat, animal protein and some vitamin consumption in breast cancer: a case control study in southern France. Int $J$ Cancer $48:$ 1-9.

94) Ronco A, De Stefani E, Mendilaharsu M, DeneoPellegrini H (1996) Meat, fat and risk of breast cancer: a case-control study from Uruguay. Int $J$ Cancer 65 : 328-31.

95) Cade J, Thomas E, Vail A (1998) Case-control study of breast cancer in south east England: nutritional factors. J Epidemiol Commun Health 52: 105-10.

96) La Vecchia C, Favero A, Franceschi S (1998)
Monounsaturated and other types of fat, and the risk of breast cancer. Eur J Cancer Prev 7 : 461-4.

97) Hirohata T, Nomura AM, Hankin JH, Kolonel LN, Lee J (1987) An epidemiologic study on the associaton between diet and breast cancer. $J$ Natl Cancer Inst 78 : 595-600.

98) Zaridze D, Lifanova Y, Maximovitch D, Day NE, Duffy SW (1991) Diet, alcohol consumption and reproductive factors in a case-control study of breast cancer in Moscow. Int J Cancer 48 : 493501.

99) Giovannucci E, Stampfer MJ, Colditz GA, Manson JE, Rosner BA, Longnecker M, Speizer FE, Willett WC (1993) A comparison of prospective and retrospective assessments of diet in the study of breast cancer. Am J Epidemiol 137 : 502-11.

100) Katsouyanni K, Trichopoulou A, Stuver S, Garas Y, Kritselis A, Kyriakou G, Stoïkidou M, Boyle P, Trichopoulos D (1994) The association of fat and other macronutrients with breast cancer: a case-control study from Greece. Br J Cancer $70: 537-41$.

101) Franceschi S, Favero A, Decarli A, Negri E, La Vecchia C, Ferraroni M, Russo A, Salvini S, Amadori D, Conti E, Montella M, Giacosa A (1996) Intake of macronutrients and risk of breast cancer. Lancet 347 : 1351-6.

102) De Stefani E, Deneo-Pellegrini H, Mendilaharsu M, Ronco A (1998) Essential fatty acids and breast cancer: a case-control study in Uruguay. Int J Cancer $76: 491-4$.

103) Santiago E, González MJ, Matos MI, Pérez CM (1998) Association between dietary fat and breast cancer in Puerto Rican postmenopausal women attending a breast cancer clinic. $P R$ Health Sci J 17 : 235-41.

104) Wirfält E, Mattisson I, Gullberg B, Johansson U, Olsson H, Berglund G (2002) Postmenopausal breast cancer is associated with high intakes of omega-6 fatty acids (Sweden). Cancer Causes Control $13: 883-93$.

105) Howe GR, Hirohata T, Hislop TG, Iscovich JM, Yuan JM, Katsouyanni K, Lubin F, Marubini E, Modan B, Rohan T, Toniolo P, Shunzhang Y (1990) Dietary factors and risk of breast cancer: combined analysis of 12 case-control studies. $J$ Natl Cancer Inst 82:561-9.

106) Boyd NF, Martin LJ, Noffel M, Lockwood GA, Tritchler DL (1993) A meta-analysis of studies of dietary fat and breast cancer risk. $\mathrm{Br} \mathrm{J}$ Cancer $68: 627-36$.

107) Hunter DJ, Spiegelman D, Adami HO, Beeson L, van den Brandt PA, Folsom AR, Fraser GE, Goldbohm RA, Graham S, Howe GR, Kushi LH, Marshall JR, McDermott A, Miller AB, Speizer FE, Wolk A, Yaun SS, Willett W (1996) Cohort 
studies of fat intake and the risk of breast cancer-a pooled analysis. $N$ Engl J Med 334 : 356-61.

108) Smith-Warner SA, Spiegelman D, Adami HO, Beeson WL, van den Brandt PA, Folsom AR, Fraser GE, Freudenheim JL, Goldbohm RA, Graham S, Kushi LH, Miller AB, Rohan TE, Speizer FE, Toniolo P, Willett WC, Wolk A, Zeleniuch-Jacquotte A, Hunter DJ (2001) Types of dietary fat and breast cancer: a pooled analysis of cohort studies. Int J Cancer 92:767-74.

109) Stemmermann GN, Nomura AM, Heilbrun LK (1984) Dietary fat and the risk of colorectal cancer. Cancer Res 44:4633-7.

110) Giovannucci E, Rimm EB, Stampfer MJ, Colditz GA, Ascherio A, Willett WC (1994) Intake of fat, meat, and fiber in relation to risk of colon cancer in men. Cancer Res 54:2390-7.

111) Järvinen R, Knekt P, Hakulinen T, Rissanen $H$, Heliövaara M (2001) Dietary fat, cholesterol and colorectal cancer in a prospective study. $\mathrm{Br}$ J Cancer 85:357-61.

112) Flood A, Velie EM, Sinha R, Chaterjee N, Lacey JV Jr, Schairer C, Schatzkin A (2003) Meat, fat, and their subtypes as risk factors for colorectal cancer in a prospective cohort of women. $A m \mathrm{~J}$ Epidemiol 158 : 59-68.

113) Jain M, Cook GM, Davis FG, Grace MG, Howe GR, Miller AB (1980) A case-control study of diet and colo-rectal cancer. Int $J$ Cancer 26 : 757-68.

114) Neugut AI, Garbowski GC, Lee WC, Murray T, Nieves JW, Forde KA, Treat MR, Waye JD, Fenoglio-Preiser C (1993) Dietary risk factors for the incidence and recurrence of colorectal adenomatous polyps. A case-control study. Ann Intern Med $118: 91-5$.

115) Benito E, Stiggelbout A, Bosch FX, Obrador A, Kaldor J, Mulet M, Muñoz N (1991) Nutritional factors in colorectal cancer risk: a case-control study in Majorca. Int J Cancer $49: 161-7$.

116) Peters RK, Pike MC, Garabrant D, Mack TM (1992) Diet and colon cancer in Los Angeles County, California. Cancer Causes Control 3 : 457-73.

117) Benito E, Cabeza E, Moreno V, Obrador A, Bosch FX (1993) Diet and colorectal adenomas: a case-control study in Majorca. Int $J$ Cancer $55: 213-9$.

118) Gaard M, Tretli S, Lфken EB (1996) Dietary factors and risk of colon cancer: a prospective study of 50,535 young Norwegian men and women. Eur J Cancer Prev 5 : 445-54.

119) Le Marchand L, Wilkens LR, Hankin JH, Kolonel LN, Lyu LC (1997) A case-control study of diet and colorectal cancer in a multiethnic population in Hawaii (United States) : lipids and foods of animal origin. Cancer Causes Con- trol $8: 637-48$.

120) Howe GR, Aronson KJ, Benito E, Castelleto R, Cornée J, Duffy S, Gallagher RP, Iscovich JM, Deng-ao J, Kaaks R, Kune GA, Kune S, Lee HP, Lee M, Miller AB, Peters RK, Potter JD, Riboli E, Slattery ML, Trichopoulos D, Tuyns A, Tzonou A, Watson LF, Whittemore AS, WuWilliams AH, Shu Z (1997) The relationship between dietary fat intake and risk of colorectal cancer: evidence from the combined analysis of 13 case-control studies. Cancer Causes Control $8: 215-28$.

121) Ghadirian $P$, Lacroix A, Maisonneuve $P$, Perret C, Potvin C, Gravel D, Bernard D, Boyle P (1997) Nutritional factors and colon carcinoma: a case-control study involving French Canadians in Montréal, Quebec, Canada. Cancer 80:85864.

122) Franceschi S, La Vecchia C, Russo A, Favero A, Negri E, Conti E, Montella M, Filiberti R, Amadori D, Decarli A (1998) Macronutrient intake and risk of colorectal cancer in Italy. Int J Cancer $76: 321-4$.

123) Levi F, Pasche C, Lucchini F, La Vecchia C (2002) Macronutrients and colorectal cancer: a Swiss case-control study. Ann Oncol 13:369-73.

124) Giovannucci E, Rimm EB, Colditz GA, Stampfer MJ, Ascherio A, Chute CC, Willett WC (1993) A prospective study of dietary fat and risk of prostate cancer. J Natl Cancer Inst 85:1571-9.

125) Veier $\phi d$ MB, Laake P, Thelle DS (1997) Dietary fat intake and risk of prostate cancer: a prospective study of 25,708 Norwegian men. Int $J$ Cancer $73: 634-8$.

126) Schuurman AG, van den Brandt PA, Dorant E, Brants HA, Goldbohm RA (1999) Association of energy and fat intake with prostate carcinoma risk: results from The Netherlands Cohort Study. Cancer 86:1019-27.

127) Whittemore AS, Kolonel LN, Wu AH, John EM, Gallagher RP, Howe GR, Burch JD, Hankin J, Dreon DM, West DW, Teh CZ, Paffenbarger RS $\mathrm{Jr}$ (1995) Prostate cancer in relation to diet, physical activity, and body size in blacks, whites, and Asians in the United States and Canada. $J$ Natl Cancer Inst 87 : 652-61.

128) Vlajinac HD, Marinkovic JM, Ilic MD, Kocev NI (1997) Diet and prostate cancer: a case-control study. Eur J Cancer 33 : 101-7.

129) Lee MM, Wang RT, Hsing AW, Gu FL, Wang T, Spitz M (1998) Case-control study of diet and prostate cancer in China. Cancer Causes Control 9:545-52.

130) Heshmat MY, Kaul L, Kovi J, Jackson MA, Jackson AG, Jones GW, Edson M, Enterline JP, Worrell RG, Perry SL (1985) Nutrition and prostate cancer: a case-control study. Prostate $6: 7-17$. 
131) Kolonel LN, Yoshizawa CN, Hankin JH (1988) Diet and prostatic cancer: a case-control study in Hawaii. Am J Epidemiol 127 : 999-1012.

132) West DW, Slattery ML, Robison LM, French TK, Mahoney AW (1991) Adult dietary intake and prostate cancer risk in Utah: a case-control study with special emphasis on aggressive tumors. Cancer Causes Control 2 : 85-94.

133) Rohan TE, Howe GR, Burch JD, Jain M (1995) Dietary factors and risk of prostate cancer: a case-control study in Ontario, Canada. Cancer Causes Control 6 : 145-54.

134) Andersson SO, Wolk A, Bergström R, Giovannucci E, Lindgren C, Baron J, Adami HO (1996) Energy, nutrient intake and prostate cancer risk: a population-based case-control study in Sweden. Int $J$ Cancer 68: 716-22.

135) Ghadirian P, Lacroix A, Maisonneuve P, Perret C, Drouin G, Perrault JP, Béland G, Rohan TE, Howe GR (1996) Nutritional factors and prostate cancer: a case-control study of French Canadians in Montreal, Canada. Cancer Causes Control $7: 428-36$.

136) Kristal AR, Cohen JH, Qu P, Stanford JL (2002) Associations of energy fat, calcium, and vitamin D with prostate cancer risk. Cancer Epidemiol Biomarkers Prev $11: 719-25$.

137) Knekt P, Seppänen R, Järvinen R, Virtamo J, Hyvönen L, Pukkala E, Teppo L (1991) Dietary cholesterol, fatty acids, and the risk of lung cancer among men. Nutr Cancer 16 : 267-75.

138) Bandera EV, Freudenheim JL, Marshall JR, Zielezny M, Priore RL, Brasure J, Baptiste M, Graham S (1997) Diet and alcohol consumption and lung cancer risk in the New York State Cohort (United States). Cancer Causes Control $8: 828-40$.

139) Veier $\phi d$ MB, Laake P, Thelle DS (1997) Dietary fat intake and risk of lung cancer: a prospective study of 51,452 Norwegian men and women. Eur J Cancer Prev 6 : 540-9.

140) Alavanja MC, Brown CC, Swanson C, Brownson RC (1993) Saturated fat intake and lung cancer risk among nonsmoking women in Missouri. J Natl Cancer Inst 85 : 1906-16.

141) De Stefani E, Deneo-Pellegrini H, Mendilaharsu M, Carzoglio JC, Ronco A (1997) Dietary fat and lung cancer: a case-control study in Uruguay. Cancer Causes Control 8 : 913-21.

142) Mohr DL, Blot WJ, Tousey PM, Van Doren ML, Wolfe KW (1999) Southern cooking and lung cancer. Nutr Cancer $35: 34-43$.

143) Swanson CA, Brown CC, Sinha R, Kulldorff M, Brownson RC, Alavanja MC (1997) Dietary fats and lung cancer risk among women: the Missouri Women's Health Study (United States). Cancer Causes Control $8: 883-93$.

144) Alavanja MC, Field RW, Sinha R, Brus CP,
Shavers VL, Fisher EL, Curtain J, Lynch CF (2001) Lung cancer risk and red meat consumption among Iowa women. Lung Cancer 34 : $37-46$.

145) De Stefani E, Brennan P, Boffetta P, Mendilaharsu M, Deneo-Pellegrini H, Ronco A, Olivera L, Kasdorf H (2002) Diet and adenocarcinoma of the lung: a case-control study in Uruguay. Lung Cancer $35: 43-51$.

146) Smith-Warner SA, Ritz J, Hunter DJ, Albanes D, Beeson WL, van den Brandt PA, Colditz G, Folsom AR, Fraser GE, Freudenheim JL, Giovannucci E, Goldbohm RA, Graham S, Kushi LH, Miller AB, Rohan TE, Speizer FE, Virtamo J, Willett WC (2002) Dietary fat and risk of lung cancer in a pooled analysis of prospective studies. Cancer Epidemiol Biomarkers Prev 11: 987-92.

147) Stolzenberg-Solomon RZ, Pietinen P, Taylor PR, Virtamo J, Albanes D (2002) Prospective study of diet and pancreatic cancer in male smokers. Am J Epidemiol 155: 783-92.

148) Michaud DS, Giovannucci E, Willett WC, Colditz GA, Fuchs CS (2003) Dietary meat, dairy products, fat, and cholesterol and pancreatic cancer risk in a prospective study. Am J Epidemiol $157: 1115-25$.

149) Ghadirian P, Simard A, Baillargeon J, Maisonneuve P, Boyle P (1991) Nutritional factors and pancreatic cancer in the francophone community in Montréal, Canada. Int J Cancer 47 : 1-6.

150) Farrow DC, Davis S (1990) Diet and the risk of pancreatic cancer in men. Am J Epidemiol 132 : 423-31.

151) Kalapothaki V, Tzonou A, Hsieh CC, Karakatsani A, Trichopoulou A, Toupadaki N, Trichopoulos D (1993) Nutrient intake and cancer of the pancreas: a case-control study in Athens, Greece. Cancer Causes Control $4: 383-9$.

152) López-Carrillo L, López-Cervantes M, Ward MH, Bravo-Alvarado J, Ramírez-Espitia A (1999) Nutrient intake and gastric cancer in Mexico. Int $J$ Cancer 83:601-5.

153) Cornée J, Pobel D, Riboli E, Guyader M, Hémon B (1995) A case-control study of gastric cancer and nutritional factors in Marseille, France. Eur $J$ Epidemiol $11: 55-65$.

154) Maclure M, Willett W (1990) A case-control study of diet and risk of renal adenocarcinoma. Epidemiology 1:430-40.

155) Riboli E, González CA, Lфpez-Abente G, Errezola M, Izarzugaza I, Escolar A, Nebot M, Hémon B, Agudo A (1991) Diet and bladder cancer in Spain: a multi-centre case-control study. Int J Cancer 49:214-9.

156) Chiu BC, Cerhan JR, Folsom AR, Sellers TA, Kushi LH, Wallace RB, Zheng W, Potter JD (1996) Diet and risk of non-Hodgkin lymphoma 
in older women. JAMA $275: 1315-21$.

157) Franceschi S, Levi F, Conti E, Talamini R, Negri E, Dal Maso L, Boyle P, Decarli A, La Vecchia C (1999) Energy intake and dietary pattern in cancer of the oral cavity and pharynx. Cancer Causes Control 10:439-44.

158) Sigurdson AJ, Chang S, Annegers JF, Duphorne CM, Pillow PC, Amato RJ, Hutchinson LP, Sweeney AM, Strom SS (1999) A case-control study of diet and testicular carcinoma. Nutr Cancer $34: 20-6$.

159) Littman AJ, Beresford SA, White E (2001) The association of dietary fat and plant foods with endometrial cancer (United States). Cancer Causes Control 12:691-702.

160) Wakai K, Takashi M, Okamura K, Yuba H, Suzuki K, Murase T, Obata K, Itoh H, Kato T, Kobayashi M, Sakata T, Otani T, Ohshima S, Ohno Y (2000) Foods and nutrients in relation to bladder cancer risk: a case-control study in Aichi Prefecture, Central Japan. Nutr Cancer 38 : 1322.

161) Lichtenstein AH, Kennedy E, Barrier P, Danford D, Ernst ND, Grundy SM, Leveille GA, Van Horn L, Williams CL, Booth SL (1998) Dietary fat consumption and health. Nutr Rev 56 : S3S28.

162) American Heart Association Nutrition Committee; Lichtenstein AH, Appel LJ, Brands M, Carnethon M, Daniels S, Franch HA, Franklin B, Kris-Etherton P, Harris WS, Howard B, Karanja N, Lefevre M, Rudel L, Sacks F, Van Horn L, Winston M, Wylie-Rosett J (2006) Diet and lifestyle recommendations revision 2006: a scientific statement from the American Heart Association Nutrition Committee. Circulation 114 : 82-96.

163) Posner BM, Franz MM, Quatromoni PA, Gagnon DR, Sytkowski PA, D'Agostino RB, Cupples LA (1995) Secular trends in diet and risk factors for cardiovascular disease: the Framingham Study. J Am Diet Assoc 95 : 171-9.

164) Kafatos A, Diacatou A, Voukiklaris G, Nikolakakis N, Vlachonikolis J, Kounali D, Mamalakis G, Dontas AS (1997) Heart disease risk-factor status and dietary changes in the Cretan population over the past $30 \mathrm{y}$ : the Seven Countries Study. Am J Clin Nutr 65 : 1882-6.

165) Porkka KV, Raitakari OT, Leino A, Laitinen S, Rasanen L, Ronnemaa T, Marniemi J, Lehti- maki T, Taimela S, Dahl M, Uhari M, Akerblom HK, Viikari JS (1997) Trends in serum lipid levels during 1980-1992 in children and young adults. The Cardiovascular Risk in Young Finns Study. Am J Epidemiol 146:64-77.

166) Feskens EJ, Kromhout D (1990) Habitual dietary intake and glucose tolerance in euglycaemic men: the Zutphen Study. Int J Epidemiol 19: 953-9.

167) Harding AH, Sargeant LA, Welch A, Oakes S, Luben RN, Bingham S, Day NE, Khaw KT, Wareham NJ, EPIC-Norfolk Study (2001) Fat consumption and $\mathrm{HbA}(1 \mathrm{c})$ levels: the EPICNorfolk study. Diabetes Care 24 : 1911-6.

168) van Dam RM, Rimm EB, Willett WC, Stampfer MJ, Hu FB (2002) Dietary patterns and risk for type 2 diabetes mellitus in U.S. men. Ann Intern Med $136: 201-9$.

169) Sasaki S, Zhang XH, Kesteloot H (1995) Dietary sodium, potassium, saturated fat, alcohol, and stroke mortality. Stroke 26:783-9.

170) Ricci S, Celani MG, Righetti E, Caruso A, De Medio G, Trovarelli G, Romoli S, Stragliotto E, Spizzichino L (1997) Fatty acid dietary intake and the risk of ischaemic stroke: a multicentre case-control study. UFA Study Group. J Neurol $244: 360-4$.

171) Tzonou A, Hsieh CC, Polychronopoulou A, Kaprinis G, Toupadaki N, Trichopoulou A, Karakatsani A, Trichopoulos D (1993) Diet and ovarian cancer: a case-control study in Greece. Int J Cancer 55:411-4.

172) van Dam RM, Huang $Z$, Giovannucci E, Rimm EB, Hunter DJ, Colditz GA, Stampfer MJ, Willett WC (2000) Diet and basal cell carcinoma of the skin in a prospective cohort of men. $A m \mathrm{~J}$ Clin Nutr $71: 135-41$.

173) Jain MG, Rohan TE, Howe GR, Miller AB (2000) A cohort study of nutritional factors and endometrial cancer. Eur J Epidemiol 16:899905.

174) Bonner MR, McCann SE, Moysich KB (2002) Dietary factors and the risk of testicular cancer. Nutr Cancer $44: 35-43$.

175) Chen H, Ward MH, Tucker KL, Graubard BI, McComb RD, Potischman NA, Weisenburger DD, Heineman EF (2002) Diet and risk of adult glioma in eastern Nebraska, United States. Cancer Causes Control 13 : 647-55. 
J Jpn Soc Nutr Food Sci 60:19-52 (2007)

\title{
Review
}

\author{
Concept of Reference Intake of Saturated Fatty \\ Acids in the Japanese Population \\ Osamu Ezaki, ${ }^{* 1}$ Masanobu Sakono, ${ }^{2}$ \\ Yoshihiro Miyake, ${ }^{3}$ and Hideki Ito ${ }^{4}$
}

(Received August 15, 2006 ; Accepted September 26, 2006)

\begin{abstract}
Summary: Basic principles of Japanese dietary reference intakes (DRIs) published in 2005 for saturated fatty acids are described in detail and evidence tables used for their establishment are presented. Increased intake of saturated fatty acids leads to increased incidences of obesity, diabetes, and myocardial infarction, whereas decreased intake leads to an increased incidence of brain (intraparenchymal) hemorrhage. Therefore, the tentative dietary goal (DG) for saturated fatty acids in individuals more than 18 years of age was set between $4.5 \%$ and $7 \%$ energy. Obesity due to increased intake of saturated fatty acids eventually causes diabetes, and an increase in saturated fatty acids leads to an increase in LDL-cholesterol concentration that eventually causes myocardial infarction. Many intervention studies have indicated that diets in which saturated fatty acids account for less than 10\% energy (NCEP step I diet) or 7\% energy (NCEP step II diet) effectively reduce LDL-cholesterol concentration and obesity. Large-scale observation studies have indicated that increased intake of saturated fatty acid or habits to eat more saturated fatty acids may lead to increased dose-dependent incidences of diabetes and myocardial infraction. Median intake of saturated fatty acids in Japanese more than 18 years of age in 2001 was $4.9-7.2 \%$ energy in males and $5.4-7.9 \%$ energy in females. Considering current saturated fatty acid intakes in Japanese and the dose-dependent effects of saturated fatty acids on the incidence of diabetes and myocardial infarction, the upper limit of saturated fatty acid intake was set at 7\% energy. Observation studies targeting Japanese populations have indicated that a lower intake of saturated fatty acids increases the incidence of brain hemorrhage. One study has shown that middle-aged Japanese individuals who had a lower intake of saturated fatty acids had a dose-dependently increased incidence of intraparenchymal hemorrhage, after consideration of confounding factors such as blood pressure, BMI, blood cholesterol, smoking and alcohol consumption. In another study, Japanese living in Hawaii who ate less that $10 \mathrm{~g} /$ day saturated fatty acid had a 2 -fold increased incidence of stroke. Considering these two studies, the lower intake limit for saturated fatty acids was set at $4.5 \%$ energy.
\end{abstract}

Key words : dietary reference intake, saturated fatty acid, myocardial infarction, stroke, diabetes mellitus

* Corresponding author (E-mail: ezaki@nih.go.jp)

${ }^{1}$ National Institute of Health and Nutrition, 1-23-1 Toyama, Shinjuku-ku, Tokyo 162-8636, Japan

${ }^{2}$ Department of Biochemistry and Applied Biosciences, University of Miyazaki, 1-1 Gakuen Kibana-dai Nishi, Miyazaki 889-2192, Japan

${ }^{3}$ Department of Public Health, Fukuoka University School of Medicine, 7-45-1 Nanakuma, Jonan-ku, Fukuoka 814-0180, Japan

${ }^{4}$ Geriatric Hospital, 35-2 Sakae-cho, Itabashi-ku, Tokyo 173-0015, Japan 